National Park Service / U.S. Geological Survey-Water Quality Partnership Program

\title{
Organic Wastewater Compounds in Water and Sediment in and near Restored Wetlands, Great Marsh, Indiana Dunes National Lakeshore, 2009-11
}


Scientific Investigations Report 2013-5186

U.S. Department of the Interior U.S. Geological Survey 
Cover: Photographs at locations in the Great Marsh, Indiana Dunes National Lakeshore showing (clockwise from upper left): a spillway conducting surface-water flow in a constructed wetland cell, November 2009, the same spillway without flow during drier conditions in late September, 2010, collection of a water sample by a USGS hydrologist for wastewater compounds in December 2009, and a particulate-organic compound integratve sampler immediately before deployment at a tributary to a constructed wetland cell in April 2011. (Photographs by Amanda L. Egler, U.S. Geological Survey) 


\section{Organic Wastewater Compounds in Water and Sediment in and near Restored Wetlands, Great Marsh, Indiana Dunes National Lakeshore, 2009-11}

By Amanda L. Egler, Martin R. Risch, David A. Alvarez, and Paul M. Bradley

National Park Service / U.S. Geological Survey-Water Quality

Partnership Program

Scientific Investigations Report 2013-5186 


\title{
U.S. Department of the Interior SALLY JEWELL, Secretary
}

\section{U.S. Geological Survey Suzette M. Kimball, Acting Director}

\author{
U.S. Geological Survey, Reston, Virginia: 2013
}

For more information on the USGS - the Federal source for science about the Earth, its natural and living resources, natural hazards, and the environment, visit http://www.usgs.gov or call 1-888-ASK-USGS.

For an overview of USGS information products, including maps, imagery, and publications, visit http://www.usgs.gov/pubprod

To order this and other USGS information products, visit http://store.usgs.gov

Any use of trade, firm, or product names is for descriptive purposes only and does not imply endorsement by the U.S. Government.

Although this information product, for the most part, is in the public domain, it also may contain copyrighted materials as noted in the text. Permission to reproduce copyrighted items must be secured from the copyright owner.

Suggested citation:

Egler, A.L., Risch, M.R., Alvarez, D.A., and Bradley, P.M., 2013, Organic wastewater compounds in water and sediment in and near restored wetlands, Great Marsh, Indiana Dunes National Lakeshore, 2009-11: U.S. Geological Survey Scientific Investigations Report 2013-5186, 52 p., http://dx.doi.org/10.3133/sir20135186. 


\section{Contents}

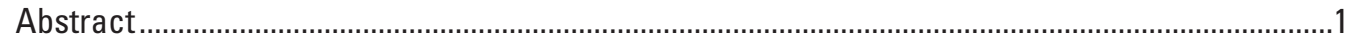

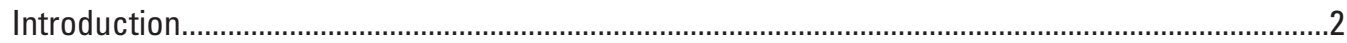

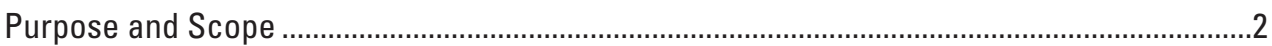

Description of the Study Area …........................................................................................

Hydrology and History of Great Marsh .............................................................................. 4

Restoration of Great Marsh in the Study Area ..................................................................4

Climate of the Study Area .............................................................................................

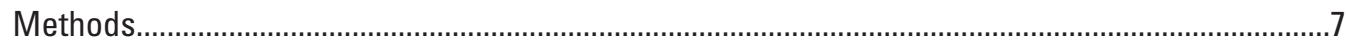

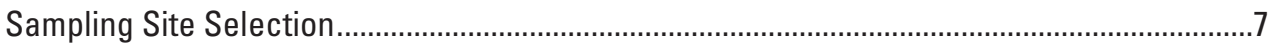

Hydrologic Data Collection .........................................................................................................8

Discrete Water-Quality Sample Collection and Analysis..........................................................10

Wetland Sediment Samples and Analysis ..................................................................................14

Laboratory Biodegradation Potential Studies............................................................................15

Quality Control Samples .............................................................................................................15

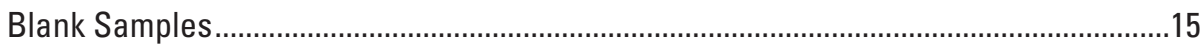

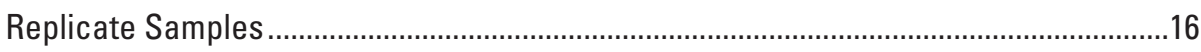

Laboratory Spike Samples .............................................................................................16

Occurrence of Organic Wastewater Compounds in Great Marsh...................................................16

Evaluation of Quality-Assurance Data ...................................................................................16

Organic Wastewater Compounds in Discrete Water Samples.................................................25

Organic Wastewater Compounds in Time-Averaged Water Samples ....................................27

Indicators of Residential Onsite Wastewater Disposal Effluent ..............................................30

Transport and Fate of Organic Wastewater Compounds in Great Marsh.........................................32

Hydrologic Influences on Organic Wastewater Compound Transport...................................32

Estimated Daily Loads of Septic Tank Indicator Compounds ....................................................35

Wetland Sediment Accumulation of Organic Wastewater Compounds .................................35

Potential for Biodegradation of Model Organic Wastewater Compounds in Sediment.........39

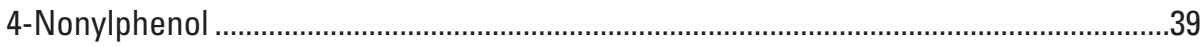



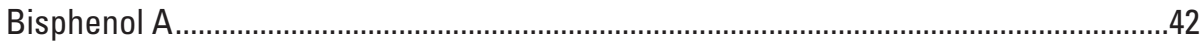

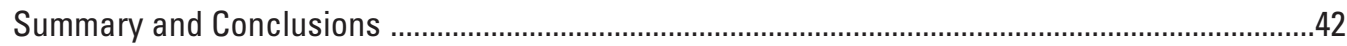

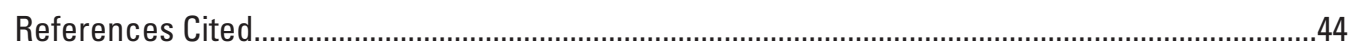

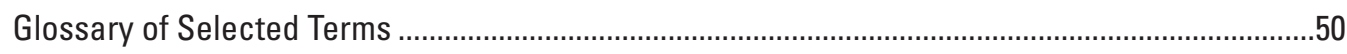

Selected Quality Assurance Terms Used in this Report................................................................52

Appendixes 1-3. Separate Excel documents available on Web only.

Appendix 1. Water-quality data.

Appendix 2. Passive sampler data.

Appendix 3. Sediment sample data. 


\section{Figures}

1. Map showing the location of the study area in and near Great Marsh at Beverly Shores, northwestern Indiana .

2. Diagrammatic hydrogeologic section showing surficial aquifers and conceptual groundwater-flow directions in the eastern half of the Indiana Dunes National Lakeshore near Beverly Shores.

3. Map showing sampling sites in and near Great Marsh at Beverly Shores, northwestern Indiana

4. Schematic of cascading restored wetland cells. .7

5. Photographs showing $A$, equipment and supplies used during installation of $B$, hand-driven well points, and $C$, a submersible pressure transducer in well point at site W3; diagram of $D$, well point installations used at sites W1, W2, and W3.

6. Photographs showing typical surface-water measurement sites: $A$, a stable culvert end at site U1 with a polar organic chemical integrative sampler ready for installation, April 2011, and $B$, a hand-driven rebar stake used as a reference point at site $\mathrm{U} 2$, July 2011

7. Photographs showing $A$, interior construction of a polar organic chemical integrative sampler and $B$, duplicate polar organic chemical integrative samplers prior to installation at site W3, April 2011.

8. Graph showing average number of organic wastewater compounds detected per discrete water sample

9. Graphs showing continuous water levels from wetland cells at sites W1, W2, and W3

10. Graphs showing $A$, continuous water levels and water levels at the time of discrete sample collection at site W2 and $B, 7$-day cumulative precipitation

11. Graphs showing $A$, continuous water levels and $B$, hourly cumulative precipitation during a heavy rain event

\section{Tables}

1. Characteristics of surface-water data-collection and sampling sites in and near Great Marsh at Beverly Shores and a National Park Service-operated precipitation monitoring site at Indiana Dunes National Lakeshore, northwestern Indiana, 2009-11

2. Types of samples and data collected at each sampling site in and near Great Marsh at Beverly Shores, northwestern Indiana, 2009-11.

3. Analytical methods used for samples collected in and near Great Marsh at Beverly Shores, northwestern Indiana, 2009-11

4. Organic wastewater compounds, polycyclic aromatic hydrocarbon compounds, and semivolatile organic compounds targeted by chemical analysis of water and wetland sediment samples collected in and near Great Marsh at Beverly Shores, northwestern Indiana, 2009-11.

5. Most frequently detected organic wastewater compounds in water samples collected in and near Great Marsh at Beverly Shores, northwestern Indiana, 2009-11.

6. Organic wastewater compounds detected in samples collected by polar organic chemical integrative samplers in and near Great Marsh at Beverly Shores, northwestern Indiana, April and November-December 2011 
7. Estrogenic potential of chemicals, expressed as estimated average water concentrations relative to estimated estradiol equivalents, in water samples collected by polar organic chemical integrative samplers in and near Great Marsh at Beverly Shores, northwestern Indiana, April and November-December 2011

8. Summary of septic tank indicator compounds detected in water samples collected in and near Great Marsh at Beverly Shores, northwestern Indiana, 2009-11 and concentrations of those compounds detected by other studies

9. Summary of continuous water-level data in wetland cells in Great Marsh at Beverly Shores, northwestern Indiana, 2009-11 .

10. Wetland cell response to a heavy rain event in Great Marsh at Beverly Shores, northwestern Indiana, June 2011

11. Water levels and streamflow at wetland spillways in Great Marsh at Beverly Shores, northwestern Indiana, 2009-11

12. Estimated daily loads of septic tank indic ator compounds in water collected at wetland spillways in Great Marsh at Beverly Shores, Indiana, 2009-11

13. Calculated total concentrations of 13 priority polycyclic aromatic hydrocarbon compounds and ratios of phenanthrene to anthracene and fluoranthene to pyrene in wetland-sediment samples collected in and near Great Marsh at Beverly Shores, northwestern Indiana, 2011, and comparison to available Sediment Quality Targets.

14. Results of microcosm biodegradation experiments for 17-ethinylestradiol, 4-nonylphenol, triclocarban, and bisphenol $\mathrm{A}$ in wetland sediment samples collected in and near Great Marsh at Beverly Shores, northwestern Indiana, 2011. 


\section{Conversion Factors, Datums, Water-Quality Units, and Abbreviations}

Inch/Pound to SI



SI to Inch/Pound

\begin{tabular}{|c|c|c|}
\hline Multiply & By & To obtain \\
\hline \multicolumn{3}{|c|}{ Length } \\
\hline millimeter (mm) & 0.03937 & inch (in.) \\
\hline meter (m) & 3.281 & foot $(\mathrm{ft})$ \\
\hline kilometer $(\mathrm{km})$ & 0.6214 & mile (mi) \\
\hline \multicolumn{3}{|c|}{ Area } \\
\hline square kilometer $\left(\mathrm{km}^{2}\right)$ & 0.3861 & square mile $\left(\mathrm{mi}^{2}\right)$ \\
\hline \multicolumn{3}{|c|}{ Volume } \\
\hline liter (L) & 33.82 & ounce, fluid (fl. oz) \\
\hline liter (L) & 0.2642 & gallon (gal) \\
\hline cubic meter $\left(\mathrm{m}^{3}\right)$ & 35.31 & cubic foot $\left(\mathrm{ft}^{3}\right)$ \\
\hline \multicolumn{3}{|c|}{ Flow rate } \\
\hline cubic meter per second $\left(\mathrm{m}^{3} / \mathrm{s}\right)$ & 35.31 & cubic foot per second $\left(\mathrm{ft}^{3} / \mathrm{s}\right)$ \\
\hline \multicolumn{3}{|c|}{ Mass } \\
\hline gram (g) & 0.03527 & ounce, avoirdupois (oz) \\
\hline kilogram (kg) & 2.205 & pound avoirdupois (lb) \\
\hline
\end{tabular}

Temperature in degrees Celsius $\left({ }^{\circ} \mathrm{C}\right)$ may be converted to degrees Fahrenheit $\left({ }^{\circ} \mathrm{F}\right)$ as follows:

${ }^{\circ} \mathrm{F}=\left(1.8 \times{ }^{\circ} \mathrm{C}\right)+32$

Temperature in degrees Fahrenheit $\left({ }^{\circ} \mathrm{F}\right)$ may be converted to degrees Celsius $\left({ }^{\circ} \mathrm{C}\right)$ as follows:

${ }^{\circ} \mathrm{C}=\left({ }^{\circ} \mathrm{F}-32\right) / 1.8$ 


\section{Datums}

Vertical coordinate information is referenced to the National Geodetic Vertical Datum of 1929 (NGVD 29)

Horizontal coordinate information is referenced to the North American Datum of 1983 (NAD 83) in this report

Altitude, as used in this report, refers to distance above the vertical datum.

\section{Water-quality and other units used in this report}

Specific conductance is given in microsiemens per centimeter at 25 degrees Celsius $(\mu \mathrm{S} / \mathrm{cm}$ at $\left.25^{\circ} \mathrm{C}\right)$.

Concentrations of chemical constituents in water are given in milligrams per liter (mg/L), micrograms per liter $(\mu \mathrm{g} / \mathrm{L})$, and nanograms per liter $(\mathrm{ng} / \mathrm{L})$. Chemical concentrations and water temperature are given in metric units.

A milligram per liter is a unit expressing the concentration of chemical constituents in solution as weight (milligrams) of solute per unit volume (liter) of water. One thousand micrograms per liter are equivalent to one milligram per liter. One thousand nanograms per liter are equivalent to one microgram per liter. For concentrations less than $7,000 \mathrm{mg} / \mathrm{L}$, the numerical value for milligrams per liter is the same as for concentrations in parts per million.

Concentrations of chemical constituents in sediment are given in micrograms per kilogram of sediment, wet weight $(\mu \mathrm{g} / \mathrm{Kg})$.

Concentrations of carbon-14 in model compounds used in the laboratory microcosm studies are reported in picocuries $(\mathrm{pCi})$ of carbon-14 per micromole of the model compound. $\mathrm{A}$ picocurie is a unit of radioactivity; 1 picocurie is defined as $3.7 \times 10^{-2}$ decays per second; or in SI terminology, $3.7 \times 10^{-2}$ becquerel. A micromole is a unit expressing the amount of a chemical substance in the number of atoms or molecules; it is computed as the weight of the element or compound, in micrograms, divided by the atomic weight of one atom or molecule of its composition elements, in grams (one micromole). 


\section{Other abbreviations or acronyms used in this report}

4-NP: 4-n-nonylphenol, a non-ionic detergent

BPA: bisphenol A

${ }^{14} \mathrm{C}$ : $\quad$ carbon-14 isotope

CCC: continuous criterion concentration

$\mathrm{CO}_{2}$ : Carbon dioxide

$\mathrm{CH}_{4}$ : methane

DEET: N,N-diethyl-meta-toluamide

EE2: $\quad 17 \alpha$-ethinylestradiol, a synthetic birth control pharmaceutical

EDC: endocrine disrupting chemicals

EEQ: estradiol equivalent

HHCB: hexahydrohexamethyl cyclopentabenzopyran

INDU: Indiana Dunes National Lakeshore

$\mathbf{K}_{\text {ow: }}$ octanol-water partition coefficients

NPS: National Park Service

NWOL: National Water Quality Laboratory

OWC: organic wastewater compound

POCIS: polar organic chemical integrative sampler

RPD: relative percent difference

SVOC: semivolatile organic compounds

TCC: triclocarban, an antibacterial compound

EPA: U.S. Environmental Protection Agency

USGS: U.S. Geological Survey

YES: Yeast estrogen screen 


\title{
Organic Wastewater Compounds in Water and Sediment in and near Restored Wetlands, Great Marsh, Indiana Dunes National Lakeshore, 2009-11
}

\author{
By Amanda L. Egler, Martin R. Risch, David A. Alvarez, and Paul M. Bradley
}

\section{Abstract}

A cooperative investigation between the U.S. Geological Survey and the National Park Service was completed from 2009 through 2011 to understand the occurrence, distribution, and environmental processes affecting concentrations of organic wastewater compounds in water and sediment in and near Great Marsh at the Indiana Dunes National Lakeshore in Beverly Shores, Indiana. Sampling sites were selected to represent hydrologic inputs to the restored wetlands from adjacent upstream residential and less developed areas and to represent discharge points of cascading cells within the restored wetland. A multiphase approach was used for the investigation. Discrete water samples and time-integrated passive samples were analyzed for 69 organic wastewater compounds. Continuous water-level information and periodic streamflow measurements characterized flow conditions at discharge points from restored wetland cells. Wetland sediments were collected and analyzed for sorptive losses of organic wastewater compounds and to evaluate of the potential for wetland sediments to biotransform organic wastewater compounds.

A total of 52 organic wastewater compounds were detected in discrete water samples at 1 or more sites. Detections of organic wastewater compounds were widespread, but concentrations were generally low and 95 percent were less than 2.1 micrograms per liter. Six compounds were detected at concentrations greater than 2.1 micrograms per liter-four fecal sterols (beta-sitosterol, cholesterol, beta-stigmastanol, and 2-beta coprostanol), one plasticizer (bis-2-ethylhexylphthalate), and a non-ionic detergent (4-nonylphenol diethoxylate). Two 1-month deployments of time-integrative passive samplers, called polar organic chemical integrative samplers, detected organic wastewater compounds at lower concentrations than were possible with discrete water samples. Isopropyl benzene (solvent), caffeine (plant alkaloid, stimulant), and hexahydrohexamethyl cyclopentabenzopyran (fragrance) were detected in more than half of the extracts from passive samplers, but they were not detected in any discrete water sample. The Yeast Estrogen Screen assay identified measurable estrogenicity in one passive sampler extract from the most downstream wetland site in both the April and November-December 2011 deployments and in passive sampler extracts from one residential and one upstream site in the November-December 2011 deployment only.

Surface-water levels in the restored wetland cells were monitored continuously using submersible pressure transducers in hand-driven well points screened in the surface water. Surface-water levels in the wetland cells responded quickly to precipitation and substantially receded within 2 days following the largest rainfall events. Seasonal patterns in water levels generally showed higher and more variable surface-water levels in the wetland cells during spring and early summer. Water levels in the wetland cells fell below the elevation of the control structures and ceased to flow over the spillways during extended dry periods (primarily late summer and early fall).

Daily loads of seven organic wastewater compounds, as indicators of septic system effluent, were estimated for samples collected at wetland outlet spillways when flow measurements could be made. Median daily loads of the indicator organic wastewater compounds increased in downstream order, and the largest median loads were measured at the most downstream site. Median daily loads were higher for samples collected in spring and summer than those collected in fall, as the higher seasonal water levels increased streamflow at the wetland outlet spillways.

Wetland sediment samples were analyzed for 84 organic wastewater compounds, polycyclic aromatic hydrocarbons, and semivolatile organic compounds to investigate the fate of contaminants in Great Marsh. The top five detected compounds by total mass in wetland sediment samples were betasitosterol, beta-stigmastanol, cholesterol, bis(2-ethylhexyl) phthalate, and phenol. Polycyclic aromatic hydrocarbons also were frequently detected in wetland sediment samples. Source apportionment of polycyclic aromatic hydrocarbon detections indicated atmospheric sources of pyrogenic compounds, rather than residential sources. Comparisons of polycyclic aromatic hydrocarbon concentrations in wetland sediment samples to sediment quality target guidelines indicated the potential for harmful effects on sediment-dwelling organisms at several sites. 
Biodegradation of select endocrine-disrupting compounds (17 $\alpha$-ethinylestradiol, 4-nonylphenol, triclocarban, and bisphenol A) in shallow wetland sediments was evaluated in laboratory experiments by using carbon-14 radiolabeled model contaminants. Substantial biodegradation of certain organic wastewater compounds were demonstrated, primarily in oxic (oxygen containing) environments. One of four modeled compounds, bisphenol A, was biodegraded in anoxic (oxygen free) environments. Only sediments collected nearest residential areas exhibited degradation of the synthetic birth control pharmaceutical, $17 \alpha$-ethinylestradiol, possibly owing to adaptation and acclimation of the indigenous microbial community to septic discharge and the resultant selection of a microbial capability for biodegradation of $17 \alpha$-ethinylestradiol.

\section{Introduction}

From 2009 through 2011, the U.S. Geological Survey (USGS), in cooperation with the National Park Service (NPS), investigated the occurrence, transport, and fate of organic wastewater compounds (OWCs) in a restored wetlands complex in the Derby Ditch watershed of Great Marsh, Indiana Dunes National Lakeshore (INDU) near Lake Michigan (fig. 1). Restoration of Great Marsh wetlands is a priority natural resource issue for INDU. Great Marsh in INDU has been restored for many reasons, including to increase native plant and animal diversity, protect the beaches and improve Lake Michigan's water quality for swimming by intercepting runoff and releasing water gradually, provide a migratory rest stop for birds near the southern shore of Lake Michigan, and protect rare species by creating high-quality plant and animal habitats (National Park Service, 2012). This investigation focused on improved understanding of the occurrence, distribution, spatial and temporal variation, and potential groundwater and surfacewater sources of OWCs in the restored wetlands.

Contributions of OWCs to the restored wetlands reflect land-use and multiple water sources within the watershed, including wastewater effluent from septic systems, runoff from asphalt-paved roads and tar-sealed driveways, runoff from storm events, atmospheric deposition, and groundwater inputs. Organic compounds associated with domestic wastewater include pharmaceuticals and personal care products (Hinkle and others, 2005). Contaminants associated with runoff from paved roads and tar-sealed driveways include several kinds of aromatic hydrocarbons and polycyclic aromatic hydrocarbons (PAHs, VanMetre and Mahler, 2010). Contaminants detected in air monitoring and potentially associated with atmospheric deposition in northwestern Indiana include aromatic hydrocarbons and PAHs (U.S. Army Corps of Engineers, 2011, 2012) and anthropogenic organic matter (Mastalerz and others, 2001). Many of these compounds affect hormone function in a variety of organisms at very low concentrations and, consequently, are considered endocrine-disrupting chemicals (EDC). Potential EDC effects on aquatic life in restored wetlands and downstream receiving waters are particular concerns, owing to continuous, multigenerational exposure of aquatic organisms to untreated wastewater. Several recent studies have demonstrated adverse effects of wastewater EDC and other OWCs on the health of freshwater fish populations (Thorpe and others, 2001; MacCoy, 2006; Lee and others, 2000).

EDCs and OWCs are often detected sporadically and at very low concentrations in environmental water samples. Sporadic detections in the study area may result from episodic contaminant releases that do not coincide with sampling events, dilution of compound concentrations below analytical detection limits by hydrologic processes, partitioning of contaminants to wetland sediments due to sorption and sedimentation processes, and/or biogeochemical transformation and degradation processes. A multiphase approach can evaluate the potential for these processes to affect concentrations of OWCs in water samples. This approach can include analysis of water samples collected at discrete times or hydrologic conditions, selective deployments and analysis of time-integrated passive samples, collection and analysis of wetland sediments, and evaluation of the biotransformation potential of wetland sediments.

\section{Purpose and Scope}

The purpose of this report is to describe the methods, data, and results of an investigation to understand the occurrence, distribution, and fate of OWCs in restored wetlands and adjacent surface water relative to potential upstream sources in Great Marsh at the Indiana Dunes National Lakeshore. This report describes the analyses of several types of data to understand the relative importance of potential sources and hydrologic and geochemical factors to the occurrence of OWCs in surface water of the restored wetland cells. Surfacewater level, precipitation, and temperature data were interpreted to describe the hydrologic condition of the restored wetland and sites upstream from the wetland cells during and between the times when samples were collected. Eight sets of discrete water-quality samples were collected at nine sampling sites in and around Great Marsh between December 2009 and December 2011, and two extended deployments of passive samplers (April 2011 and November-December 2011) were conducted at four sampling sites. One set of wetland sediment samples was collected at five sampling sites in April 2011 to understand the potential for OWCs to sorb and accumulate in wetland sediments. An additional set of wetland sediment samples was collected in July 2011 for use in a laboratory microcosm assessment of the potential for biotransformation of OWCs. 


\section{Description of the Study Area}

The study area described in this report is located in the 4.83 square mile $\left(\mathrm{mi}^{2}\right)$ Derby Ditch drainage basin of northeastern Porter County, northwestern Indiana (fig. 1).

The investigation focused on a $0.29 \mathrm{mi}^{2}$ area of restored wetland in the town of Beverly Shores, bounded by Lake Shore County Road to the east, Broadway to the west, Beverly Drive to the north, and natural areas to the south. The Derby Ditch drainage basin is situated within the Calumet Lacustrine Plain physiographic unit, an abandoned lake bottom that was the site of Lake Chicago near the end of the Wisconsin glacial period (Hardy, 1984). Major stages of glacial Lake Chicago are represented by long, terraced sand ridges trending in an east-west arc through the area. Sand dunes and interdunal wetlands now cover many of these ridges (Hardy, 1984). The town of Beverly Shores has a population of 613 and approximately 530 housing units, 35 percent of which are occupied for only seasonal, recreational, or occasional use (U.S. Census Bureau, 2010).



EXPLANATION

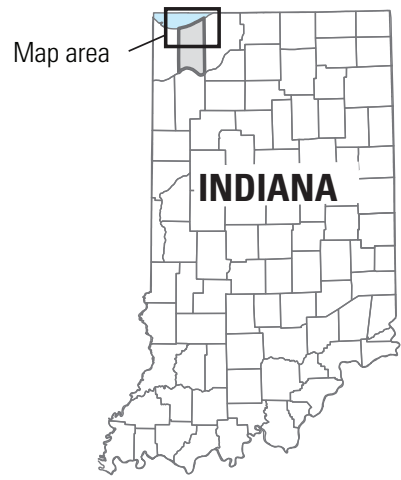

Figure 1. Location of the study area in and near Great Marsh at Beverly Shores, northwestern Indiana. 


\section{Hydrology and History of Great Marsh}

Great Marsh is an interdunal wetland formed approximately 4,000 years ago between the Tolleston dunes on the north and the Calumet dunes on the south (National Park Service, 2012). It formed as an open body of water in a single watershed and flowed to Lake Michigan through outlets to the west in the Dunes Creek basin, and to the east near Michigan City, Ind. Great Marsh evolved from an open-water body to a complex and diverse wetland system with areas of conifer swamp, wet prairie, fen, bog, sedge meadow, and marsh (National Park Service, 2012). At one time, it stretched 12 miles (mi) from Burns Harbor, Ind. east to Michigan City, Ind. Today, Great Marsh is $10 \mathrm{mi}$ long with an average width of 0.5 mi (National Park Service, 2012).

Drainage ditches have altered the hydrology of streams in and around Great Marsh. Before construction of Derby Ditch, no streams drained from the part of Great Marsh in the study area directly into Lake Michigan (Hardy, 1984). Multiple drainage projects in Porter County between 1875 and 1925 divided Great Marsh into three drainage basins-Dunes Creek, Derby Ditch, and Brown/Kintzele Ditch (Cook and Jackson, 1978). Ditches were generally constructed to lower the water table so that the former wetlands would be acceptable for agriculture and residential development.

Surface drainage from Great Marsh and the restored wetlands in the study area now discharges through Derby Ditch into Lake Michigan. The southern drainage divide of the Derby Ditch watershed coincides with the crest of the Lake Border moraine (shown in section on fig. 2). The northern drainage divide of Great Marsh in the Derby Ditch watershed is the dune-beach complex under a residential part of Beverly Shores between Great Marsh and Lake Michigan. Drainage divides on the east-northeast and west-southwest boundaries of the Derby Ditch watershed are much more subtly defined because of the low topographic relief in Great Marsh along this orientation.

Shallow wetland sediments in Great Marsh study area are mostly composed of peat or peat-sand mixtures that range in thickness from about 2 feet (ft) to $20 \mathrm{ft}$ thick near Beverly Shores (Thompson, 1987; Buszka and others, 2011). Mastalerz and others (2001) documented anthropogenic organic carbon - composed of particles of unburned or partially burned coal, coked particulates, bitumen, and coal-combustion fly ash in the uppermost $0.7 \mathrm{ft}$ of peat at a site in the area of the current wetland. Subsurface peat fires during a 1952 drought burned about 20 acres in Great Marsh near Beverly Shores (Henrichs, 1952).

Great Marsh in the study area is underlain by three glacial aquifers - the surficial aquifer, the subtill aquifer, and the basal sand aquifer - typically separated by variable thicknesses of glacial till and lacustrine clay and silt. The surficial aquifer is the uppermost aquifer in this setting and consists of fine- to medium-grained dune, beach, and lacustrine sands and gravels (fig. 2; also Beaty, 1994; Thompson, 1987; Buszka and others, 2011). The saturated thickness of the surficial aquifer ranges from about $5 \mathrm{ft}$ along the Lake Michigan shoreline to $30-35 \mathrm{ft}$ in the areas south of Beverly Shores near highway U.S. 12 (Watson and others, 2002; Shedlock and others, 1994) and near areas drained by Derby Ditch. Groundwater in the surficial aquifer typically flows from the dune-beach complex toward discharges in Great Marsh, ditches, and Lake Michigan (fig. 2).

The surficial aquifer generally is unconfined but can be locally confined by interlaminated silt and clay, marls, calcareous mud, and organic peat deposits (Shedlock and others, 1994). Confining units of interbedded till and glacial lacustrine clay and silt separate the surficial aquifer from the underlying subtill aquifer and the subtill aquifer from the basal sand aquifer. Groundwater in the surficial aquifer discharges to the wetland area from the adjacent dunes (fig. 2).

Development of the town of Beverly Shores in the late 1920s led to the construction of roads, low embankments, drainage pipes, ditches, and culverts to drain adjacent parts of Great Marsh in the Derby Ditch watershed and the dunes and interdunal wetlands between Great Marsh and Lake Michigan. Homes were developed mostly in the dunes and interdunal wetlands between Great Marsh and Lake Michigan, although some were built in or on the periphery of Great Marsh. When Congress authorized creation of INDU in the mid-1960s, much of the acreage in Beverly Shores between highway U.S. 12 and the residential part of the dune-beach complex was included within INDU (fig. 2). Land use in the study area is primarily residential along the streets in Beverly Shores and is a mixture of residential and commercial uses along U.S. 12. The INDU is downwind of the industrialized areas in northwestern Indiana and northeastern Illinois along Lake Michigan. During the past century, air pollution from steel and coke production, oil refining and storage, and other industries (Souch and others, 1999; Winchester and Nifong, 1971) has deposited organic particulates to Lake Michigan sediments (Griffin and Goldberg, 1983) and to wetlands in the study area (Mastalerz and others, 2001).

\section{Restoration of Great Marsh in the Study Area}

Great Marsh is the largest interdunal wetland on the Lake Michigan shoreline. Restoration activities in the Derby Ditch watershed and Great Marsh began in 1993 with the collection of data to establish existing conditions in the wetlands. Restoration of the part of the study area bounded by Broadway, Beverly Drive, Lake Shore County Road and highway U.S. 12 (fig. 3) began in 1999. Ditches along Lake Shore County Road were plugged. South-to-north and southeast-to-northwest oriented ditches on the southern boundary of Great Marsh shown on figure 3 were blocked by placement of bank material into the ditches. A former east to west ditch in this part of Great Marsh adjacent to Beverly Drive conveyed water to Broadway through a series of culverts associated with an abandoned road system. The flow of water through these culverts was blocked through removal or plugging of the culverts. On the abandoned roads, spillways were constructed to facilitate 


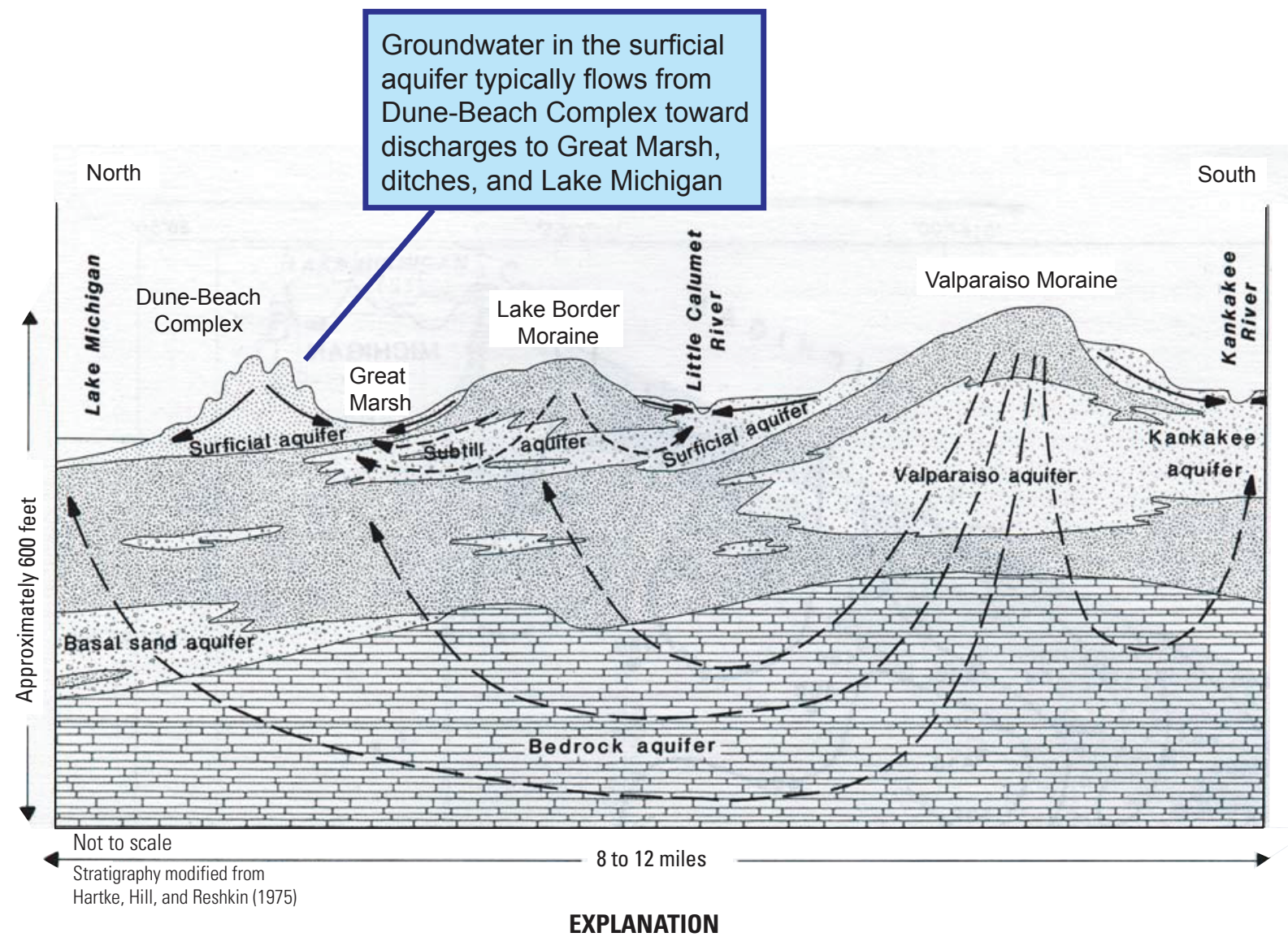

Dune, beach and lacustrine sand

Till and glacial-lacustrine clay and silt

Glacial-lacustrine sand-Interbedded with

layers of silt and clay

Shale and carbonate bedrock

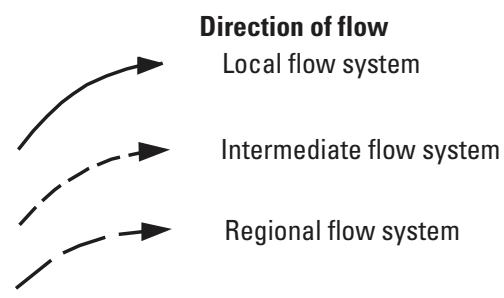

Figure 2. Surficial aquifers and conceptual groundwater-flow directions in the eastern half of the Indiana Dunes National Lakeshore near Beverly Shores. (Modified from Shedlock and others, 1994)

development of average water depths sufficient to produce deep marsh and wet meadow/wet prairie types of wetland.

Primary spillways were constructed by the NPS within the wetlands to retain water at depths and durations sufficient to maximize a richness of wetland types including deep marsh and wet meadow/wet prairie wetlands. Deep marsh wetlands require permanent flooding through the full year to semipermanent flooding through the growing season (Cowardin and others, 1979.) For Great Marsh, deep marsh conditions had about 1 to $2 \mathrm{ft}$ of water depth. Wet meadow/wet prairie wetlands require temporarily flooded conditions during brief periods of the growing season to intermittently flooded conditions during irregular, non-seasonal periods (Cowardin and others, 1979). For Great Marsh, wet meadow and wet prairie conditions have surface-water depths typically ranging from about $1 \mathrm{ft}$ during wet conditions to below land surface during drier conditions. The spillways were constructed larger than the ditches they replaced to facilitate movement of excess water into Derby Ditch and subsequently into Lake Michigan. These plugs, diversions, and spillways serve to create a system of cascading wetland cells (fig. 4).

Water generally flows southwest through the study area towards the spillway at Derby Ditch and Beverly Drive, where it turns north to flow towards Lake Michigan. Abandoned roadbeds were modified to increase water circulation within the restored wetland and to create multiple flow paths between the wetland cells. Flow control structures were designed to include redundancy such that temporary blockage 


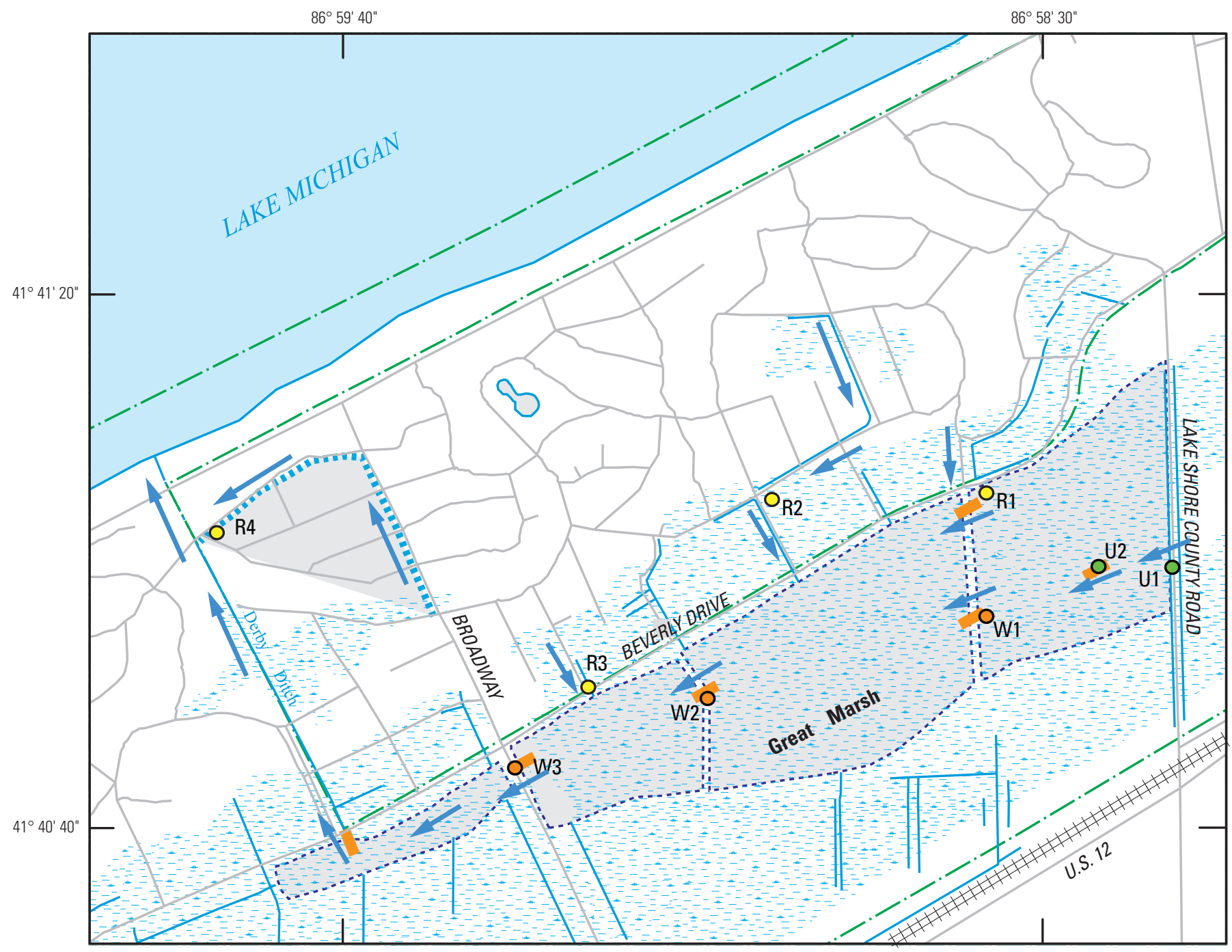

Base from U.S. Geological Survey digital data 1983, 1:100,000 Universal Transverse Mercator projection, Zone 16 Standard parallel $0^{\circ}$ (Equator), Central meridian $87^{\circ} \mathrm{W}$ North American Datum 1983, Wetland area from

U.S. Fish and Wildlife Service, National Wetland Inventory,

1992, 1:2,000,000, as served from http://indianamap.org
Wetland area from U.S. Fish and Wildlife Service, National Wetland Inventory, 1992, 1:2,000,000, as served from http://indianamap.org

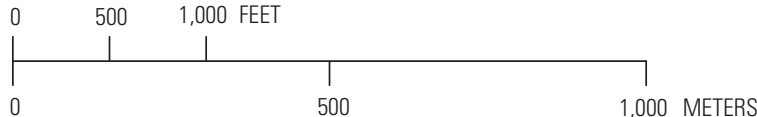

\section{EXPLANATION}

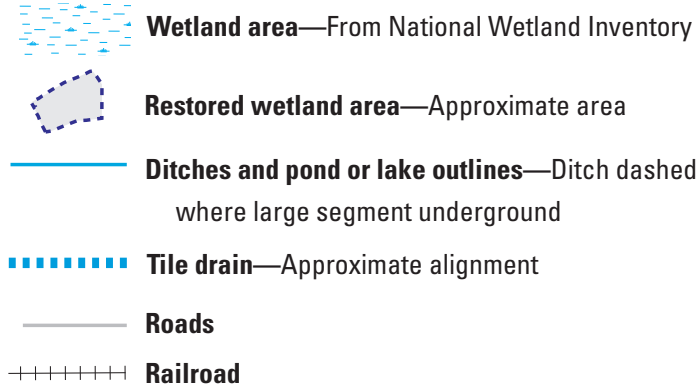

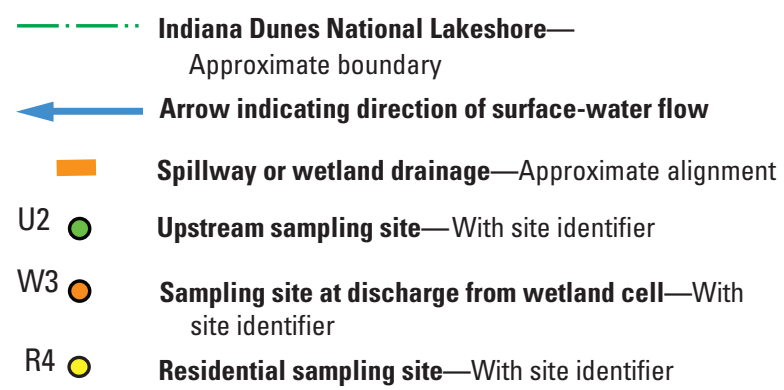

Figure 3. Sampling sites in and near Great Marsh at Beverly Shores, northwestern Indiana. 


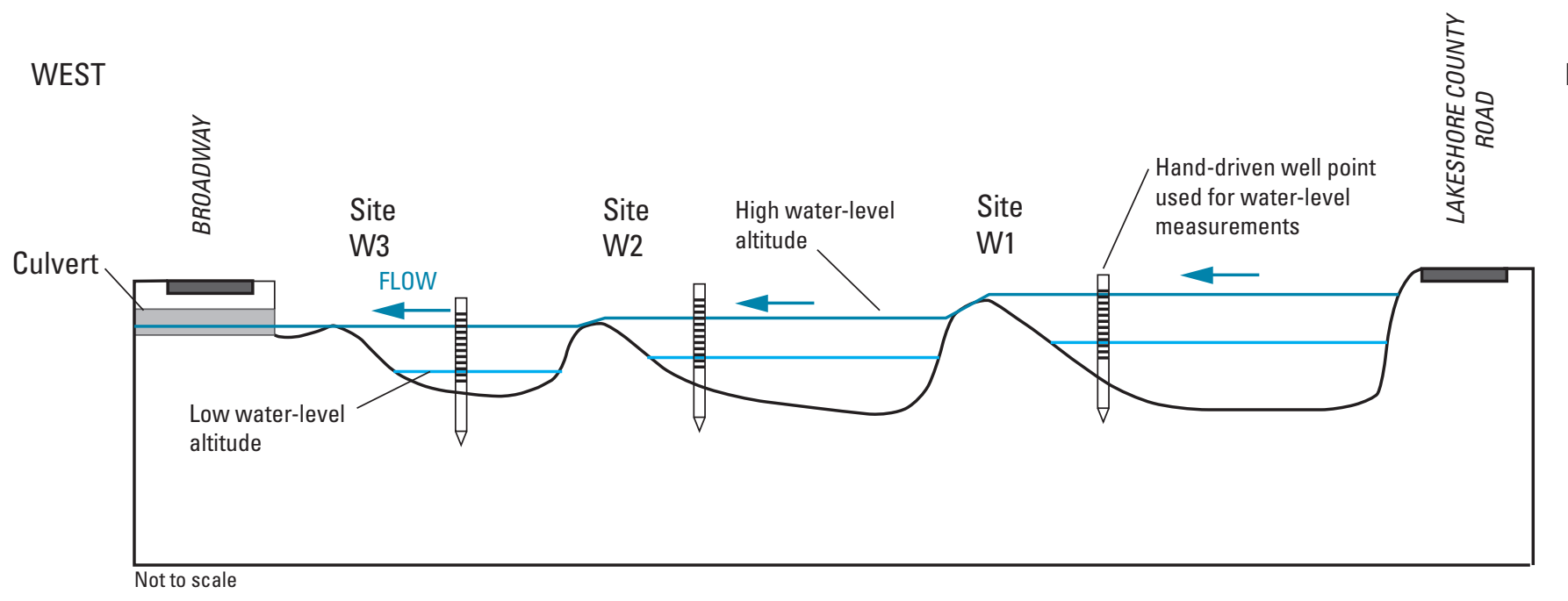

Figure 4. Cascading restored wetland cells.

of some structures would not impede overall flow toward Lake Michigan (Daniel Mason, National Park Service, written commun., 2009). Although constructed wetlands can increase the retention time of water and thereby increase opportunities for biofiltration and removal of contaminants, the restoration of Great Marsh was also designed to minimize the duration of higher surface-water levels in and around the marsh during storm events.

Transport of OWCs in Great Marsh is driven by hydrologic processes. OWCs can enter Great Marsh through surface-water runoff, groundwater infiltration, and atmospheric deposition (wet and dry). OWCs typically move through the wetland, into Derby Ditch, and subsequently into Lake Michigan. OWCs may be taken-up and held (adsorbed) in wetland sediments of the marsh and may also be altered by biological processes within the wetland sediments, a process known as "biotransformation." Surface-water levels and flow though the marsh are affected by precipitation, evaporation, evapotranspiration, and groundwater infiltration as well as other factors such as condition of the wetland spillways.

\section{Climate of the Study Area}

The climate in Indiana has four distinct seasons: frequently cold winters, a transitional spring season with active precipitation, hot, humid summers followed by typically drier, cooler autumns (Scheeringa, 2002). Spring and early summer months typically have the most rainfall, and winter months are typically drier, except near Lake Michigan. Lake Michigan microclimates affect the study area, and air temperature extremes are moderated by the proximity to the lake (Scheeringa, 2002). Soil moisture conditions in the wetland part of the study area become saturated during the winter and spring with recharge from snowmelt and precipitation and decline through the growing season (Buszka and others, 2011; Scheeringa, 2002).

\section{Methods}

A multiphase approach was used to evaluate the occurrence, distribution, and fate of OWCs in restored wetlands and adjacent surface water in Great Marsh at INDU. This section describes the methods used for selection of sampling sites; collection of hydrologic data; collection and analysis of discrete water-quality samples, passive time-integrated water samples, and wetland sediment samples; and evaluation of the biotransformation potential of wetland sediments.

\section{Sampling Site Selection}

Nine sampling sites were selected in and around Great Marsh (table 1, fig. 3) to include different potential inputs of OWCs to the restored wetland cells and to represent discharge from each of three wetland cells. Sites U1 and U2 are "upstream" sites, representing the water draining towards the restored wetland cells in Great Marsh from the east. Sites R1, R2, R3, and R4 are "residential" sites, representing the water draining into the restored wetland cells and Derby Ditch from the residential areas of Beverly Shores served by onsite residential wastewater disposal systems. Sites R1 and R3 are immediately adjacent to Beverly Drive and the wetland. $\mathrm{R} 2$ is located within the residential area in a ditch that drains groundwater and surface-water runoff (Buszka, 2011). Site R4 is a subsurface drain tile that flows directly into Derby Ditch immediately upstream of Lake Michigan without intercepting the wetland. R4 was sampled intermittently to represent the character of the shallow groundwater within the residential area. Sites W1, W2, and W3 are "wetland" sites representing discrete surface-water discharge between restored wetland cells within the reconstructed marsh. Each site is located immediately upstream of a primary spillway at the exit of a restored wetland cell. Site W3 is the most downstream restored wetland cell of the study area and integrates the water quality and surface-water flow from the seven upstream sites. 
Table 1. Characteristics of surface-water data-collection and sampling sites in and near Great Marsh at Beverly Shores and a National Park Service-operated precipitation monitoring site at Indiana Dunes National Lakeshore, northwestern Indiana, 2009-11.

[Sampling site locations are shown in figure 3; the location of the precipitation data collection site is shown in figure 1. USGS, U.S. Geological Survey; ddmmss.S, latitude in degrees, minutes, seconds; dddmmss.s, longitude in degrees, minutes, seconds; NGVD 29, National Geodetic Vertical Datum of 1929; Cul, Culvert; Co, county, Rd, road, IN, Indiana, W, west, NE, northeast, SE southeast, S, south; n.a. not applicable---no USGS site identifier; n.m., not measured]

\begin{tabular}{|c|c|c|c|c|c|}
\hline $\begin{array}{l}\text { Sampling } \\
\text { site } \\
\text { name }\end{array}$ & $\begin{array}{l}\text { USGS station- } \\
\text { identification } \\
\text { number }\end{array}$ & Formal site name & $\begin{array}{c}\text { Latitude } \\
\text { (north, in ddmmss.s) }\end{array}$ & $\begin{array}{c}\text { Longitude } \\
\text { (west, in ddd. } \\
\text { mmss.s) }\end{array}$ & $\begin{array}{c}\text { Measuring point } \\
\text { altitude } \\
\text { (feet above NGVD 29) }\end{array}$ \\
\hline \multicolumn{6}{|c|}{ Upstream sites: relative to restored wetland cells } \\
\hline U1 & 414103086581701 & $\begin{array}{l}\text { Cul } 601 \text { Lakeshore Co Rd at } \\
\text { Beverly Shores, IN }\end{array}$ & 414102.9 & 865816.8 & 604.99 \\
\hline $\mathrm{U} 2$ & 414104086582501 & $\begin{array}{l}\text { Spillway W Of Lakeshore Co Rd } \\
\text { at Beverly Shores }\end{array}$ & 414104.0 & 865825.0 & 604.79 \\
\hline \multicolumn{6}{|c|}{ Residential area sites: sites with surface water that drains from residential areas and that are upstream from restored wetland cells } \\
\hline $\mathrm{R} 1$ & 414106086583701 & $\begin{array}{l}\text { Cul } 602 \text { NE Beverly and Wells at } \\
\text { Beverly Shores, IN }\end{array}$ & 414105.6 & 865836.9 & $600.42^{1}$ \\
\hline $\mathrm{R} 2$ & 414106086585801 & $\begin{array}{l}\text { Cul } 603 \text { SE Idler And St Clair at } \\
\text { Beverly Shores }\end{array}$ & 414105.7 & 865858.1 & 601.24 \\
\hline R3 & 414045086591501 & $\begin{array}{l}\text { Cul } 503 \text { NE Beverly Dr-Pearson } \\
\text { at Beverly Shores }\end{array}$ & 414050.4 & 865915.4 & $598.06^{1}$ \\
\hline $\mathrm{R} 4$ & 414103086595401 & $\begin{array}{l}\text { Tile Drain SE Stillwater and } \\
\text { Fairwater, Beverly Shores }\end{array}$ & 414102.8 & 865953.9 & n.m. \\
\hline \multicolumn{6}{|c|}{ Restored wetland sites: sites immediately above discharge spillways from restored wetland cells 1, 2, and 3} \\
\hline W1 & 414100086583601 & $\begin{array}{l}\text { Spillway Wells Rd S of Beverly } \\
\text { at Beverly Shores }\end{array}$ & 414059.8 & 865836.4 & 602.83 \\
\hline W2 & 414049086590101 & $\begin{array}{l}\text { Spillway Constance S of Beverly } \\
\text { at Beverly Shores }\end{array}$ & 414049.2 & 865901.3 & 600.03 \\
\hline \multirow[t]{2}{*}{ W3 } & 414046086592201 & $\begin{array}{l}\text { Spillway SE Broadway and } \\
\text { Beverly at Beverly Shores }\end{array}$ & 414045.5 & 865922.2 & 600.75 \\
\hline & & Precipitation site & & & \\
\hline IN-34 & n.a. & $\begin{array}{l}\text { Indiana Dunes National } \\
\text { Lakeshore Weather Station }\end{array}$ & 413754.5 & 870517.2 & n.m. \\
\hline
\end{tabular}

${ }^{1} \mathrm{R} 1$ and R3 elevations were resurveyed June 2009 after replacement of culverts.

\section{Hydrologic Data Collection}

Hydrologic data collected for this study were streamflow measurements made at the time of sample collection and continuous recording of surface-water levels at sites W1, W2, and W3 from December 2009 to December 2011. Streamflow measurements were made using a hand-held acoustic Doppler velocity meter when flow and water depth across the spillways were sufficient for instrument operation. Streamflow measurements at sites $\mathrm{W} 1, \mathrm{~W} 2$, and $\mathrm{W} 3$ provided data used to calculate instantaneous loads (mass/unit of time) of OWCs discharged from wetland cells. It was not practical to measure streamflow at sites U1, U2, R1, R2, and R3, because of very slow or no-flow conditions.

Continuous surface-water levels were recorded at the wetland sites. Hand-driven wells (fig. 5) were installed immediately upstream of water-level control structures at sites $\mathrm{W} 1$, W2 and W3. Wells had stainless-steel mesh screens located in and open to the surface water and were equipped with submersible pressure transducers (vented to the atmosphere) to record surface-water level observations on a 30-minute interval. Tape-down inspections from established reference points were made during sampling visits to confirm the accuracy of the transducer measurements of surface-water level, and corrections were made and applied between site visits when applicable. Short-term changes in surface-water levels recorded in wetland cells were in response to precipitation, debris accumulation on control structures, beaver activity, and site maintenance activities including clearing of blocked culverts.

For sampling sites where continuous surface-water level data were not collected, reference points were established using stable culverts or hand-driven rebar stakes (fig. 6). Surface-water levels were measured from the reference points at all sites at the time of sample collection. Altitudes of reference points were surveyed to a common vertical datum 

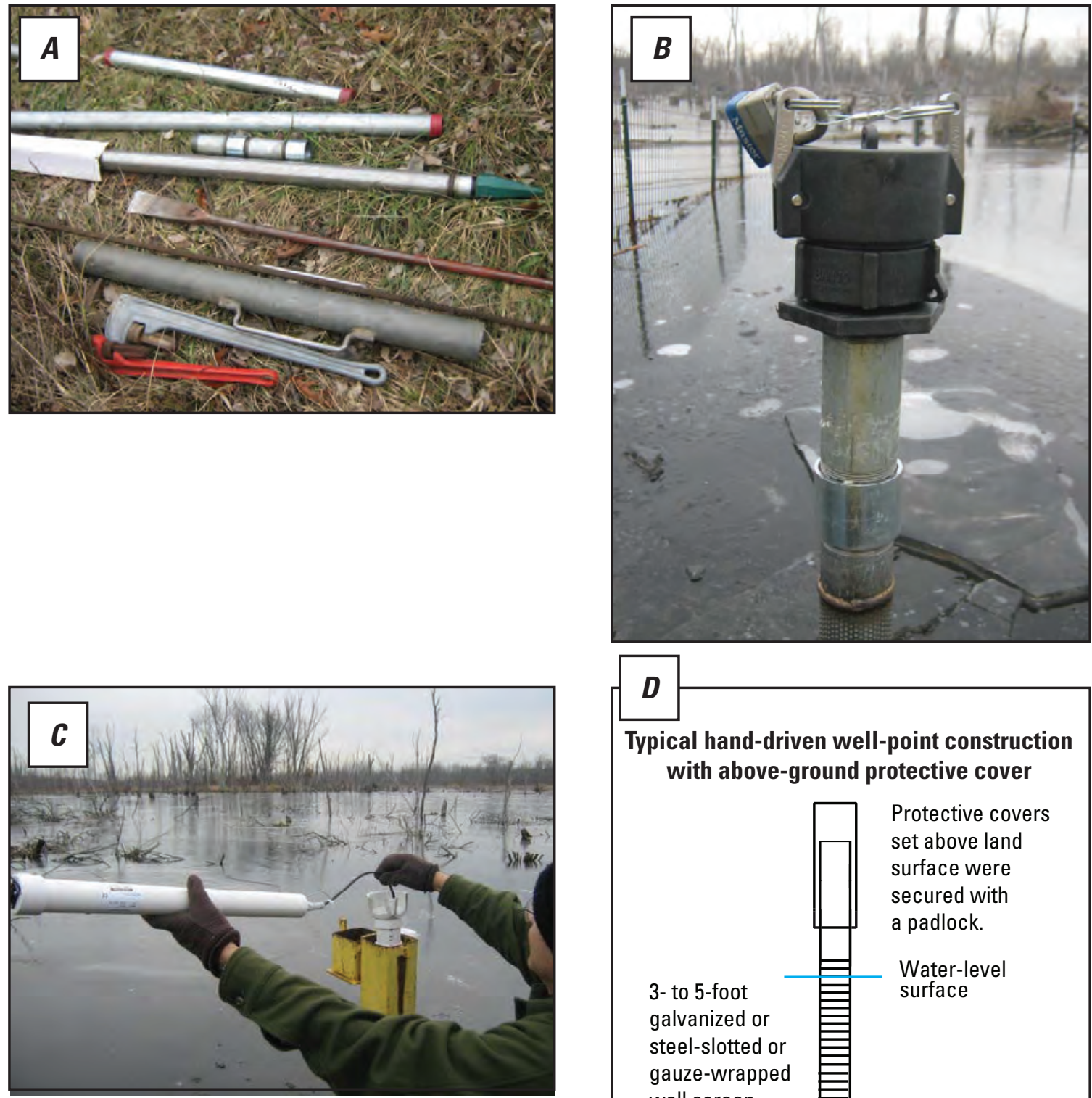

\begin{tabular}{|l|l|l|}
\hline Typical hand-driven well-point construction \\
with above-ground protective cover
\end{tabular}

Figure 5. A, equipment and supplies used during installation of $B$, hand-driven well points, and $C$, a submersible pressure transducer in well point at site W3; diagram of $D$, well point installations used at sites W1, W2, and W3. (Photographs by Amanda L. Egler, U.S. Geological Survey, December 2009) 

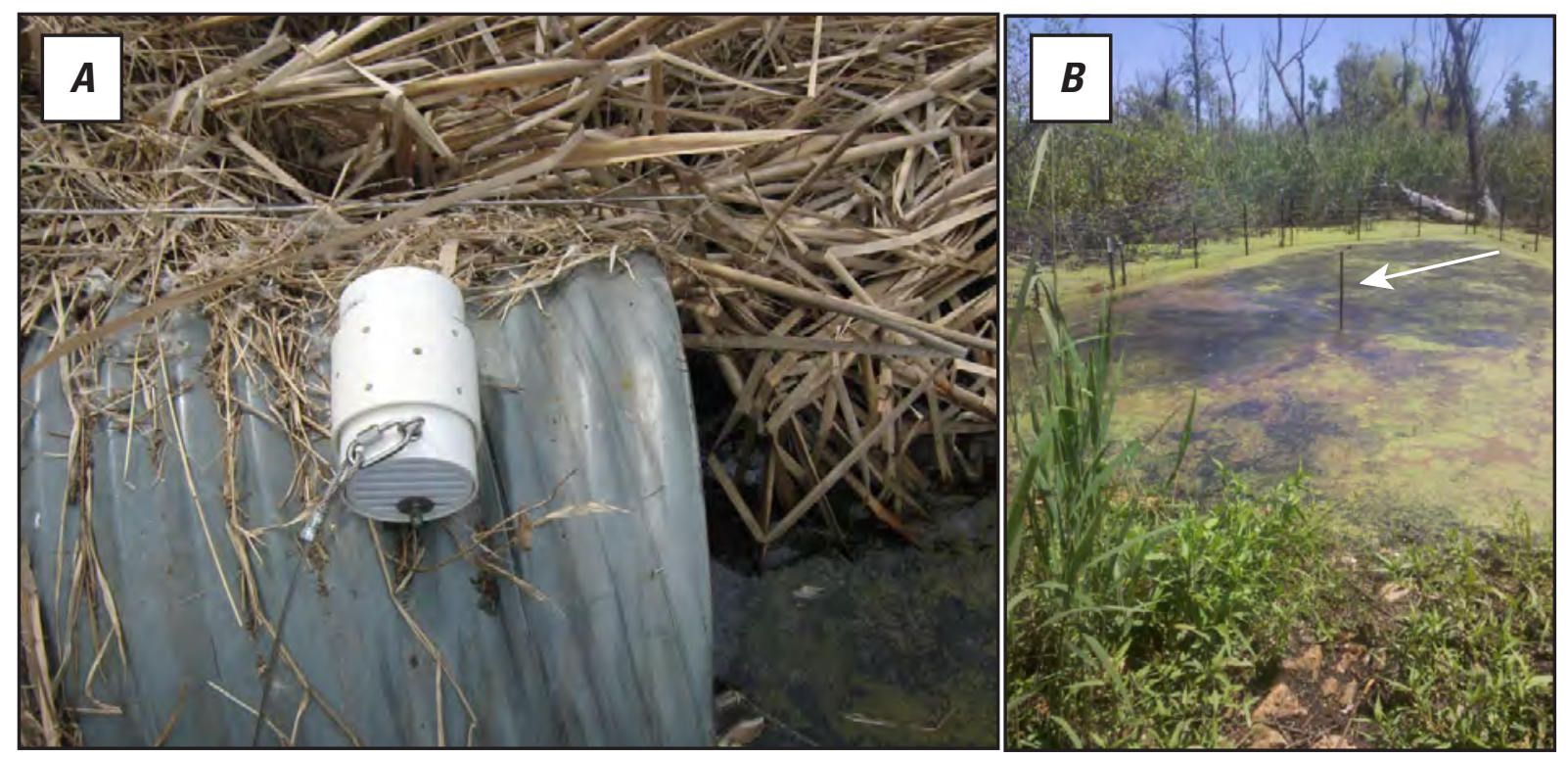

Figure 6. Typical surface-water measurement sites: $A$, a stable culvert end at site U1 with a polar organic chemical integrative sampler ready for installation, April 2011, and $B$, a hand-driven rebar stake used as a reference point at site U2, July 2011. (Photographs by Amanda L. Egler, U.S., Geological Survey)

to enable comparison of water-level changes and differences between wetland cells. Surface-water level reference points were established by an optical level survey in December 2009 and are referenced to the National Geodetic Vertical Datum of 1929 (NGVD29). The accuracy of the datum of most reference points was within $0.02 \mathrm{ft}$.

Precipitation and ambient air-temperature data were compiled from a digital rain gage at National Atmospheric Deposition Program Station (IN 34), (National Atmospheric Deposition Program, 2011), located at the INDU headquarters, approximately $4 \mathrm{mi}$ southwest of the study area (fig. 1). Buszka and others (2011) determined that daily precipitation data from this station were well correlated with and adequately represented precipitation in Great Marsh near Beverly Shores, based on an analysis of 13 months of data.

\section{Discrete Water-Quality Sample Collection and Analysis}

Sample collection (U.S. Geological Survey, 2006) and equipment cleaning procedures (Wilde, 2004; Wilde and others 2009) were followed to avoid inadvertent introduction of contaminants to the samples because several compounds of interest are present in commonly used products, such as soaps, fragrances, insect repellants, and beverages. Because of low velocities and visibly low amounts of suspended sediment at the sampling sites, grab samples were collected directly into a prebaked, amber glass bottle using a stainless-steel ladle and a glass or a stainless-steel funnel. Following collection, samples were immediately chilled and shipped overnight to the USGS National Water Quality Laboratory (NWQL) in Lakewood, Colorado for analysis (table 3). Field measurements of water temperature, specific conductance, $\mathrm{pH}$ and dissolved oxygen were made on-site with a multi-parameter water-quality meter (table 3). The meter was calibrated and checked each day of sample collection. Concentrations of OWCs were determined by continuous liquid-liquid extraction and capillary-column gas chromatography/mass spectrometry (Zaugg, Smith, and Schroeder, 2006; table 3). Compounds identified by the method are listed in table 4 and include alkylphenol ethoxylate nonionic surfactants and their degradates, food additives, fragrances, antioxidants, flame retardants, plasticizers, industrial solvents, disinfectants, fecal sterols, polycyclic aromatic hydrocarbons, and often-used domestic pesticides.

Two sets of "exploratory" samples were collected and analyzed as alternate indicators of wastewater and nutrient inputs from upstream and residential sites to the restored wetland cells (tables 2 and 3). In June 2010, samples from five sampling sites were analyzed at USGS-NWQL for supplemental constituents including fluoride, boron, ammonia, nitrate plus nitrite, nitrite, total nitrogen, orthophosphate, phosphorous, and methylene blue active substances. In December 2011, additional samples were collected from all nine sampling sites and analyzed at USGS-NWQL for fluoride, ammonia, nitrate plus nitrite, nitrite, total nitrogen, orthophosphate, and phosphorous.

Passive samplers were deployed twice at four sites for 28 and 30 day sampling periods in April and November to December 2011, respectively (tables 2 and 3). Polar organic chemical integrative samplers (POCIS) provided a timeintegrated evaluation of the presence of OWCs in water at selected sites between water-sampling events (fig. 7). POCIS use organic carbon as a sorbent to mimic the accumulation of organic compounds in aquatic organisms and can be used as a surrogate for their exposure to OWCs in water. POCIS can be deployed for weeks to months. The POCIS absorb dissolved 
chemicals continuously from the water, excluding chemicals associated with particulate, suspended sediment, or colloidal matter. During a typical 30-day exposure, a POCIS potentially can absorb chemicals from tens to hundreds of liters (L) of water, allowing for the detection of chemicals at low concentrations or those that are present only episodically. This time integration of ambient conditions is not readily achievable using standard sampling methods that collect discrete water samples.

POCIS were deployed at four sampling sites: U1, R1, $\mathrm{R} 2$, and W3. Approximately 35 percent of residences in Beverly Shores are occupied only for seasonal, recreational, or occasional use (U.S. Census Bureau, 2010), mostly in the warm summer months. The spring deployment (April 2011) was intended to represent wet conditions preceding the arrival of part-time summer resident population. The fall deployment (November-December 2011) was intended to represent dry conditions following their departure.

Each POCIS deployment included one canister (containing four POCIS discs) installed at each of four selected sampling sites and one duplicate canister installed at a single site (fig. 7). Following techniques described by Alvarez (2010), canisters were placed in culverts for protection from photodegredation and vandalism, installed horizontally to align with the principal direction of flow, and anchored with stainless steel hardware. Field measurements of $\mathrm{pH}$, temperature, specific conductance, and dissolved oxygen, as well as general observations regarding flow, bottom conditions, and water depth were recorded at the time of installation and retrieval. Field-blank canisters were transported with the environmental samplers and opened to the environment during the time of deployment and retrieval of each canister. One laboratoryblank sample collected by POCIS was prepared and analyzed per set of samplers. Upon retrieval, the samplers were shipped to the USGS Columbia Environmental Research Center in Columbia, Missouri for extraction. One disc was extracted for a yeast estrogen screen (YES) assay (Routledge and Sumpter, 1996; Rastall and others, 2004), two discs were combined for analyses of OWCs, and the fourth disc was archived, pending results from analyses of the other three extracts.

The POCIS discs designated for analysis of OWCs were extracted using 25 milliliter (mL) of an 80:20 volume-to-volume ratio dichloromethane: methyl-tert-butyl ether solution. The POCIS discs for YES and archive were each extracted with $25 \mathrm{~mL}$ of methanol. Extracts were reduced in volume by rotary evaporation and blowdown under high-purity nitrogen to approximately $1 \mathrm{~mL}$. Combined extracts from two POCIS discs for OWC analysis were filtered through 0.45 micrometer

Table 2. Types of samples and data collected at each sampling site in and near Great Marsh at Beverly Shores, northwestern Indiana, 2009-11.

[Sampling site locations are shown in figure 3. NWQL, U.S. Geological Survey National Water Quality Laboratory; POCIS, polar organic chemical integrative sampler; PAH, polycyclic aromatic hydrocarbon, n.m., not measured; X, indicates sample collected or measurement made; n.c., not collected]

\begin{tabular}{|c|c|c|c|c|c|c|c|}
\hline \multirow[t]{2}{*}{$\begin{array}{l}\text { Sampling } \\
\text { site name }\end{array}$} & \multirow[t]{2}{*}{$\begin{array}{l}\text { Water-level } \\
\text { altitude, } 30 \text { minute } \\
\text { interval data } \\
\text { (December } 2009 \text { to } \\
\text { December 2011) }\end{array}$} & \multirow[t]{2}{*}{$\begin{array}{c}\text { Surface-water samples } \\
\text { collected for analysis } \\
\text { of organic wastewater } \\
\text { compounds, December } \\
2009 \text { to December 2011, } \\
\text { number of samples } \\
\text { per site }\end{array}$} & \multicolumn{2}{|c|}{$\begin{array}{l}\text { Surface-water samples } \\
\text { collected for analysis of } \\
\text { nutrients and selected } \\
\text { inorganic constituents }\end{array}$} & \multirow[t]{2}{*}{$\begin{array}{l}\text { Surface-water } \\
\text { samples collected } \\
\text { by POCIS, 28-day } \\
\text { deployment in } \\
\text { April } 2011 \text { and } 30 \text { - } \\
\text { day deployment in } \\
\text { November, } 2011\end{array}$} & \multirow[t]{2}{*}{$\begin{array}{l}\text { Bed sediment } \\
\text { samples col- } \\
\text { lected for analy- } \\
\text { sis of organic } \\
\text { wastewater and } \\
\text { PAH compounds, } \\
\text { April } 2011\end{array}$} & \multirow[t]{2}{*}{$\begin{array}{l}\text { Bed sedi- } \\
\text { ment samples } \\
\text { collected for } \\
\text { biotransforma- } \\
\text { tion micro- } \\
\text { cosm tests, } \\
\text { July } 2011\end{array}$} \\
\hline & & & $\begin{array}{l}\text { June } \\
2010\end{array}$ & $\begin{array}{c}\text { December } \\
2011\end{array}$ & & & \\
\hline \multicolumn{8}{|c|}{ Upstream sites: relative to restored wetland cells } \\
\hline U1 & n.m. & 8 & $\mathrm{X}$ & $\mathrm{X}$ & $\mathrm{X}$ & $\mathrm{X}$ & $\mathrm{X}$ \\
\hline $\mathrm{U} 2$ & n.m. & 7 & $\mathrm{X}$ & $\mathrm{X}$ & n.c. & n.c. & n.c. \\
\hline \multicolumn{8}{|c|}{ Residential area sites: sites with surface water that drains from residential areas and that are upstream from restored wetland cells } \\
\hline $\mathrm{R} 1$ & n.m. & 8 & $\mathrm{X}$ & $\mathrm{X}$ & $\mathrm{X}$ & $\mathrm{X}$ & n.c. \\
\hline $\mathrm{R} 2$ & n.m. & 8 & n.c. & $\mathrm{X}$ & $\mathrm{X}$ & $\mathrm{X}$ & $\mathrm{X}$ \\
\hline $\mathrm{R} 3$ & n.m. & 8 & n.c. & $\mathrm{X}$ & n.c. & n.c. & n.c. \\
\hline R4 & n.m. & 4 & $\mathrm{X}$ & $\mathrm{X}$ & n.c. & n.c. & n.c. \\
\hline \multicolumn{8}{|c|}{ Restored wetland sites: sites immediately above discharge spillways from restored wetland cells 1, 2, and 3} \\
\hline W1 & $\mathrm{X}$ & 8 & $\mathrm{X}$ & $X$ & n.c. & n.c. & n.c. \\
\hline W2 & $\mathrm{X}$ & 8 & n.c. & $X$ & n.c. & $X$ & $X$ \\
\hline W3 & $X$ & 8 & n.c. & $X$ & $X$ & $X$ & n.c. \\
\hline
\end{tabular}




\section{Organic Wastewater Compounds in Water and Sediment, Indiana Dunes National Lakeshore, 2009-11}

Table 3. Analytical methods used for samples collected in and near Great Marsh at Beverly Shores, northwestern Indiana, 2009-11.

[OWC, organic wastewater compound; PAH, polycyclic aromatic hydrocarbon; USGS, U.S. Geological Survey; USGS-NWQL, U.S. Geological Survey National Water Quality Laboratory; USGS-INWC, U.S. Geological Survey Indiana Water Science Center; USGS-CERC, U.S. Geological Survey Columbia Environmental Research Center; SCH, schedule; LC, lab code; n.a., not applicable; POCIS, polar organic chemical interactive sampler]

\begin{tabular}{|c|c|c|c|c|c|}
\hline Media & $\begin{array}{l}\text { Constituent/ } \\
\text { parameter }\end{array}$ & Laboratory & $\begin{array}{c}\text { Laboratory schedule } \\
\text { or labcode }\end{array}$ & Analysis & Reference \\
\hline Water & Organic wastewater compounds & USGS-NWQL & $\mathrm{SCH} 4433$ & $\begin{array}{l}\text { Liquid/liquid extraction } \\
\text { and capillary-column } \\
\text { gas chromatography/ } \\
\text { mass spectrometry }\end{array}$ & $\begin{array}{l}\text { Zaugg, Smith, and } \\
\text { Schroeder (2006) }\end{array}$ \\
\hline \multirow[t]{7}{*}{ Water } & Nutrients & USGS-NWQL & SCH 2711 & $\begin{array}{l}\text { Various methods listed } \\
\text { below }\end{array}$ & \\
\hline & Nitrogen, ammonia as $\mathrm{N}$ & USGS-NWQL & LC 3116 & $\begin{array}{l}\text { Method ID: I-2525-89, } \\
\text { I-2522-90; colo- } \\
\text { rimetry, salicylate- } \\
\text { hypochlorite, } \\
\text { automated-segment- } \\
\text { ed flow }\end{array}$ & Fishman (1993) \\
\hline & Nitrogen, nitrite & USGS-NWQL & LC 3117 & $\begin{array}{l}\text { Method ID: I-2540-90; } \\
\text { colorimetry, diazoti- } \\
\text { zation, } \\
\text { automated-segment- } \\
\text { ed flow }\end{array}$ & Fishman (1993) \\
\hline & Nitrogen, nitrite + nitrate & USGS-NWQL & LC 3156 & $\begin{array}{l}\text { Method ID: I-2547-11; } \\
\text { colorimetric determi- } \\
\text { nation by enzymatic } \\
\text { reduction }\end{array}$ & $\begin{array}{l}\text { Patton and Kryskalla } \\
\text { (2011) }\end{array}$ \\
\hline & $\begin{array}{l}\text { Total nitrogen } \\
\text { (NH3+NO2+NO3+organic), } \\
\text { unfiltered }\end{array}$ & USGS-NWQL & LC 2756 & $\begin{array}{l}\text { Method ID: I-4650-03; } \\
\text { alkaline persulfate } \\
\text { digestion }\end{array}$ & $\begin{array}{l}\text { Patton and Kryskalla } \\
\text { (2003) }\end{array}$ \\
\hline & Phosphorus, phosphate, ortho & USGS-NWQL & LC 3118 & $\begin{array}{l}\text { Method ID: I-2601-90; } \\
\text { colorimetry, phos- } \\
\text { phomolybdate, } \\
\text { automated-segment- } \\
\text { ed flow }\end{array}$ & Fishman (1993) \\
\hline & Phosphorus & USGS-NWQL & LC 2333 & $\begin{array}{l}\text { EPA } 365.1 \text {; semiauto- } \\
\text { mated colorimetrry }\end{array}$ & O'Dell (1993) \\
\hline Water & Fluoride & USGS-NWQL & LC 31 & $\begin{array}{l}\text { Electrometric, ion- } \\
\text { selective electrode, } \\
\text { automated-segment- } \\
\text { ed flow }\end{array}$ & $\begin{array}{l}\text { Fishman and } \\
\text { Friedman (1989) }\end{array}$ \\
\hline Water & Boron & USGS-NWQL & LC 2110 & $\begin{array}{l}\text { Inductively compled } \\
\text { plasma-atomic emis- } \\
\text { sion spectrometry }\end{array}$ & $\begin{array}{l}\text { Struzeski and others } \\
\text { (1996) }\end{array}$ \\
\hline Water & $\begin{array}{l}\text { Methylene blue active sub- } \\
\text { stances }\end{array}$ & USGS-NWQL & LC 96 & Spectrophotommetry & $\begin{array}{l}\text { Burkhardt and others } \\
\text { (1995) }\end{array}$ \\
\hline
\end{tabular}


Table 3. Analytical methods used for samples collected in and near Great Marsh at Beverly Shores, northwestern Indiana, 2009-11.-Continued

[OWC, organic wastewater compound; PAH, polycyclic aromatic hydrocarbon; USGS, U.S. Geological Survey; USGS-NWQL, U.S. Geological Survey National Water Quality Laboratory; USGS-INWC, U.S. Geological Survey Indiana Water Science Center; USGS-CERC, U.S. Geological Survey Columbia Environmental Research Center; SCH, schedule; LC, lab code; n.a., not applicable; POCIS, polar organic chemical interactive sampler]

\begin{tabular}{|c|c|c|c|c|c|}
\hline Media & $\begin{array}{l}\text { Constituent/ } \\
\text { parameter }\end{array}$ & Laboratory & $\begin{array}{c}\text { Laboratory schedule } \\
\text { or labcode }\end{array}$ & Analysis & Reference \\
\hline Water & Temperature & USGS-INWC & n.a. & $\begin{array}{l}\text { In-situ measurement } \\
\text { with multiparameter } \\
\text { instrument }\end{array}$ & Wilde (2006) \\
\hline Water & $\mathrm{pH}$ & USGS-INWC & n.a. & $\begin{array}{l}\text { In-situ measurement } \\
\text { with multiparameter } \\
\text { instrument }\end{array}$ & $\begin{array}{l}\text { Ritz and Collins } \\
\text { (2008) }\end{array}$ \\
\hline Water & Specific conductance & USGS-INWC & n.a. & $\begin{array}{l}\text { In-situ measurement } \\
\text { with multiparameter } \\
\text { instrument }\end{array}$ & $\begin{array}{l}\text { Radtke and others } \\
\text { (2005) }\end{array}$ \\
\hline Water & Dissolved oxygen & USGS-INWC & n.a. & $\begin{array}{l}\text { In-situ measurement } \\
\text { with multiparameter } \\
\text { instrument }\end{array}$ & $\begin{array}{l}\text { Ritz and Collins } \\
\text { (2008): } \\
\text { Lewis (2006) }\end{array}$ \\
\hline Sediment & Organic wastewater compounds & USGS-NWQL & SCH 5433 & $\begin{array}{l}\text { Pressurized solvent } \\
\text { extraction, solid- } \\
\text { phase extraction, and } \\
\text { capillary-column gas } \\
\text { chromatography/ } \\
\text { mass spectrometry }\end{array}$ & $\begin{array}{l}\text { Burkhardt and others } \\
\text { (2006) }\end{array}$ \\
\hline Sediment & $\begin{array}{l}\text { Polynuclear aromatic hydrocar- } \\
\text { bons and semivolatile organic } \\
\text { compounds }\end{array}$ & USGS-NWQL & SCH 5506 & $\begin{array}{l}\text { Pressurized solvent } \\
\text { extraction, solid- } \\
\text { phase extraction, and } \\
\text { capillary-column gas } \\
\text { chromatography/ } \\
\text { mass spectrometry }\end{array}$ & $\begin{array}{l}\text { Zaugg, Burkhardt, } \\
\text { and others (2006) }\end{array}$ \\
\hline POCIS & Yeast estrogenic survey & USGS-CERC & n.a. & $\begin{array}{l}\text { Recombinant yeast } \\
\text { screen, spectropho- } \\
\text { tometry }\end{array}$ & $\begin{array}{l}\text { Alvarez, Cranor, } \\
\text { Perkins, Clark, and } \\
\text { others (2008), } \\
\text { also Alvarez, } \\
\text { Cranor, Perkins, } \\
\text { Schroeder, and } \\
\text { others (2008) }\end{array}$ \\
\hline POCIS & Organic wastewater compounds & USGS-NWQL & LC 8068 & $\begin{array}{l}\text { Polystyrene-divinyl- } \\
\text { benzene solid-phase } \\
\text { extraction and } \\
\text { capillary-column gas } \\
\text { chromatography/ } \\
\text { mass spectrometry }\end{array}$ & $\begin{array}{l}\text { Zaugg and others } \\
\text { (2002) }\end{array}$ \\
\hline
\end{tabular}



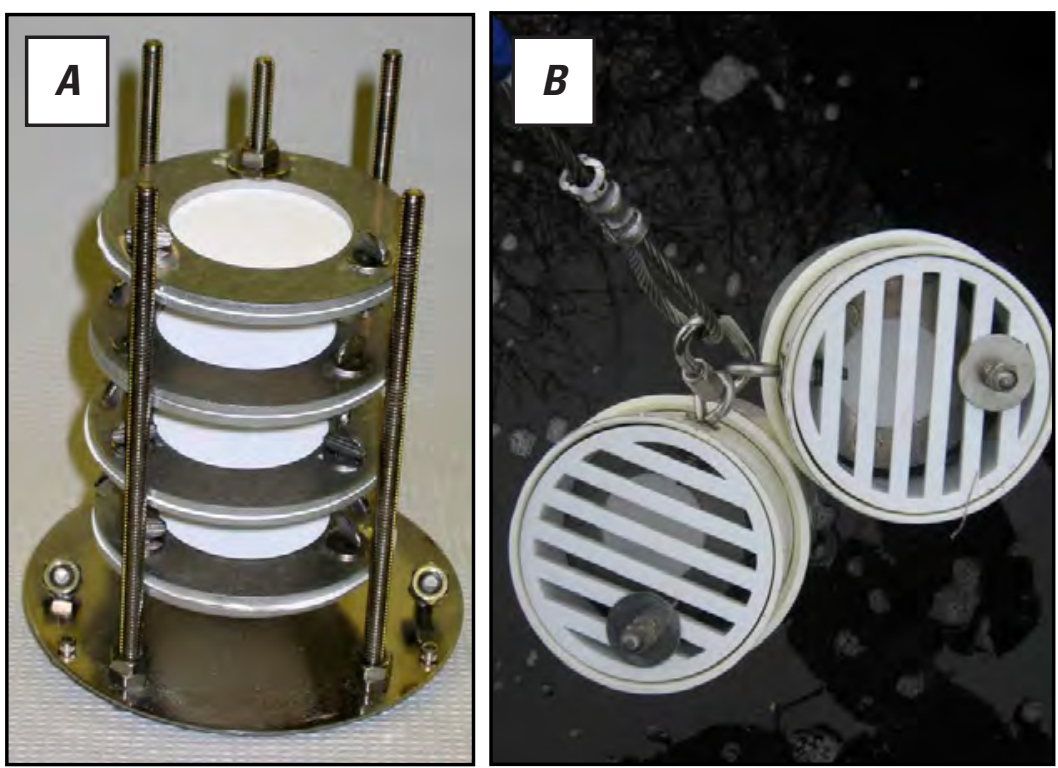

Figure 7. Photographs showing $A$, interior construction of a polar organic chemical integrative sampler and $B$, duplicate polar organic chemical integrative samplers prior to installation at site W3, April 2011. (Photographs by David A. Alvarez $(A)$ and Amanda L. Egler (B), U.S. Geological Survey)

$(\mu \mathrm{m})$ polyvinylidene fluoride filter cartridges containing sodium sulfate to aid in drying, and they were then transferred into amber glass ampoules, the solvent volume was adjusted to $1.0 \mathrm{~mL}$ of methylene chloride, and the ampoules were flame sealed. These ampoules were shipped to the USGS-NWQL for analysis following methods described in Zaugg and others (2002).

POCIS extracts used in a YES assay were used to identify the presence of estrogenic or estrogen-mimicking compounds. The YES assay utilizes recombinant yeast cells transfected with the human estrogen receptor. Upon binding these cells to an estrogen or estrogen-mimicking chemical, a cascade of biochemical reactions occurs that creates a color change that can be measured spectrophotometrically (Routledge and Sumpter, 1996; Rastall and others, 2004). POCIS extracts from each site were screened for total estrogenicity in conjunction with a series of negative (solvent) and positive (17 $\beta$-estradiol) controls (Alvarez, Cranor, Perkins, Clark, and others, 2008; Alvarez, Cranor, Perkins, Schroeder, and others, 2008; Rastall and others, 2004). Estradiol equivalent factors (EEQ) for the samples were calculated to provide a relative measure of estrogenicity. An EEQ estimates the amount of a common natural hormone, $17 \beta$-estradiol, that would be needed to produce a response similar to that of the complex mixture of chemicals sampled at each site. EEQ values are intended to measure the potential biological effects of the mixture of chemicals present in the sample, and therefore, are not compared to individual compounds in this report. Reference standards and positive and negative controls for the YES assay were employed during the study.

Bioavailable concentrations of OWCs in samples collected by POCIS were converted from raw concentrations in units of nanograms (ng) per POCIS into estimated concentrations in water using published and estimated sampling rates and models (Alvarez and others, 2004, 2010). POCIS uptake kinetics (sampling rates) are required to estimate aquatic concentrations of environmental contaminants. Uptake of chemicals into a passive sampler follows linear, curvilinear, and equilibrium phases of sampling. Integrative, or linear, sampling is the predominant phase for sampling of chemicals by the POCIS for exposure periods of up to 2 months. Previous data indicate that many chemicals of interest remain in the linear phase of sampling for at least 56 days (Alvarez and others, 2004, 2007). Therefore, the use of a linear uptake model (eq. 1) for the calculation of ambient water concentrations was justified. During the linear uptake phase the ambient chemical concentration, in nanograms per liter $\left(C_{\mathrm{w}}\right)$ was determined by

$$
C_{\mathrm{w}}=N / R_{\mathrm{s}} t
$$

where

$N \quad$ is the amount of the chemical sampled by a POCIS, in nanograms,

$R_{\mathrm{s}} \quad$ is the sampling rate in liters per day, and

$t$ is the exposure time in days.

\section{Wetland Sediment Samples and Analysis}

One set of wetland sediment samples was collected April 29, 2011, at five sampling sites (U1, R1, R2, W2, and W3) to identify the presence of OWCs in shallow wetland sediments (table 2). Equipment decontamination and cleaning 
procedures (Wilde, 2004) were followed to avoid inadvertent contamination of samples. Wetland sediment samples were collected with a stainless steel scoop by scooping bottom sediment directly into baked glass jars. Samples were chilled and shipped overnight to USGS-NWQL for analysis. Wetland sediment samples were analyzed for 57 OWCs by pressurized solvent extraction, solid-phase extraction, and capillary-column gas chromatography/mass spectrometry (Burkhardt and others, 2006). Concentrations of 38 PAHs and other semivolatile organic compounds (SVOCs) were analyzed with a pressurized solvent extraction system using an isopropyl alcohol/ water mixture, followed by solid-phase extraction and capillary column gas chromatography/mass spectrometry (table 3; Zaugg, Burkhardt, and others, 2006) Laboratory analysis of wetland sediment samples included addition and recovery of six surrogate compounds.

\section{Laboratory Biodegradation Potential Studies}

This section describes the methods used in a series of carbon-14 $\left({ }^{14} \mathrm{C}\right)$ radiotracer-based microcosm experiments focused on potential microbial degradation of OWCs in shallow wetland sediments collected from upstream site U1, residential site R2, and restored wetland site W2 (fig. 3).

Radiolabeled model compounds were used only in controlled laboratory microcosm studies and none were used in field or environmental activities by this study.

The potential for in situ biodegradation of OWCs was studied using aqueous solutions of the following ${ }^{14} \mathrm{C}$-radiolabeled compounds: The synthetic birth control pharmaceutical, 17 $\alpha$-ethinylestradiol (EE2); a highly branched isomer of 4-n-nonylphenol (4-NP194); the antibacterial compound, triclocarban (TCC); and the plasticizer, bisphenol A (BPA). Each compound had radiochemical purities greater than 98 percent and was obtained from commercial sources. Each of these model contaminants is considered an endocrine disrupting chemical with estrogenic activity (Chen and others, 2008; Cousins and others, 2002; Kim and others, 2004). The ${ }^{14} \mathrm{C}$ radiolabel for each compound was located on an aromatic ring deemed critical for binding with the estrogen binding site. Therefore, mineralization of the model compound to radiolabeled carbon dioxide $\left({ }^{14} \mathrm{CO}_{2}\right)$ or radiolabeled methane $\left({ }^{14} \mathrm{CH}_{4}\right)$ indicates cleavage of the aromatic ring and loss of estrogenic activity. Commercially available radiolabeled bicarbonate $\left(\mathrm{H}^{14} \mathrm{CO}_{3}{ }^{-}\right)$and ${ }^{14} \mathrm{CH}_{4}$ (radiochemical purities greater than 98 percent) were used as standards for calibration and method development.

Experimental wetland sediment microcosms were prepared in quintuplicate as described in Bradley and others $(2007,2008,2009)$ and were composed of $10 \mathrm{~mL}$ serum vials with $5 \mathrm{~mL}$ of saturated sediment (approximately 5 grams of dry sediment and $3 \mathrm{~mL}$ water) and an atmosphere of air (oxic treatments) or ultrapure helium (anoxic treatments). Oxic conditions were defined as headspace oxygen concentrations of 2-21 percent by volume. Anoxic conditions were defined as headspace oxygen concentrations below the analytical detection limit ( 0.02 percent by volume). Duplicate autoclaved sediment control microcosms and a single sediment-free control microcosm were prepared for each sediment and substrate combination by autoclaving three separate times for 1 hour.

Microcosms were incubated in the dark at 23 degrees Celsius $\left({ }^{\circ} \mathrm{C}\right)$ for 230 days.

Concentrations of methane $\left(\mathrm{CH}_{4}\right)$, carbon dioxide $\left(\mathrm{CO}_{2}\right)$, ${ }^{14} \mathrm{CH}_{4}$, and ${ }^{14} \mathrm{CO}_{2}$ in the microcosm headspace were monitored by analyzing $0.5 \mathrm{~mL}$ of headspace using gas chromatography with thermal conductivity detection and radiometric detection, respectively. Compound separation was achieved by isocratic $\left(80^{\circ} \mathrm{C}\right)$, packed-column ( 3 meters of $13 \mathrm{x}$ molecular sieve) gas chromatography using a Hewlett-Packard 5890 series II plus gas chromatograph. The headspace sample volumes were replaced with pure oxygen (oxic treatments) or helium (anoxic treatments). Dissolved phase concentrations of ${ }^{14} \mathrm{CH}_{4}$ and ${ }^{14} \mathrm{CO}_{2}$ were estimated based on Henry's Law partition coefficients that were determined experimentally as described in Bradley and others $(2001,2002)$. The radiometric detector output was calibrated by liquid scintillation counting using $\mathrm{H}^{14} \mathrm{CO}_{3}^{-}$. Headspace oxygen concentrations were monitored throughout the study using thermal conductivity detection gas chromatography to confirm the maintenance of oxic and anoxic conditions.

\section{Quality Control Samples}

Quality control samples, including field-blank samples, field-replicate samples, and laboratory-spike samples were collected and analyzed to evaluate for possible biases introduced by artifacts from sampling and processing or by interference from the sampling matrix. In this study, the results reported for analysis of water, POCIS samples, and wetland sediment samples are referred to as environmental samples. Fieldreplicate samples were collected sequentially after collection of environmental water and sediment samples and during the same deployment periods as environmental POCIS samples. Field-blank discrete water samples and POCIS samples were also prepared at the time of sample collection.

For each set of discrete water samples, one field blank and one field replicate were collected and analyzed. One field-replicate sample was collected with the wetland sediment samples. One replicate canister was installed at a single site during each deployment of passive samplers, along with fieldblank samples for each POCIS sampler. Laboratory surrogate spikes were performed for both water and sediment sample analyses.

\section{Blank Samples}

Environmental concentrations in discrete water samples less than five times the concentrations reported in corresponding field-blank samples were censored to less than the reporting limit for discussion and calculations presented in 
this report. The estimated water concentrations from POCIS samples presented in this report have been background corrected by subtracting the average blank response from the field values. Fabrication and field blanks for the POCIS samples were used to determine evidence of contamination from sampler construction, transport, or handling. Fabrication blanks are POCIS samples that were constructed concurrently with the deployed POCIS, but that were stored frozen in an inert atmosphere until processing of the entire sample set began (Alvarez and others, 2007). Field blanks are POCIS samples that account for contamination during transport to and from study sites and during deployment and retrieval of the deployed samplers (Alvarez and others, 2007). All data presented for POCIS samples have been blank corrected by subtracting the concentrations of compounds detected in the associated field blanks.

\section{Replicate Samples}

Field-replicate samples were used to measure natural variability of the OWC concentrations in the water and the variability associated with sample collection and analysis. Concentrations of OWCs in the field-duplicate samples (Concentration $_{\mathrm{FD}}$ ) were compared with the concentrations in the environmental samples (Concentration ${ }_{\mathrm{ES}}$ ) by computing the relative percent difference (RPD) (appendix table 1-6) when estimated or detected concentrations were reported in both samples. Relative percent difference is the nonnegative difference of the two concentrations divided by the average of the concentrations, expressed as a percentage.

$$
R P D=\left|\frac{\left(\text { Concentration }_{\mathrm{ES}}-\text { Concentration }_{\mathrm{FD}}\right)}{\left(\text { Concentration }_{\mathrm{ES}}+\text { Concentration }_{\mathrm{FD}}\right) / 2}\right| \times 100
$$

\section{Laboratory Spike Samples}

Each water and sediment sample (including blanks, replicates, and POCIS samples) was spiked with known concentrations of chemically representative surrogate compounds prior to sample preparation and extraction at the laboratory to examine for sample processing problems and matrix effects (Zaugg and others, 2002; Zaugg, Burkhardt, and others, 2006; Zaugg, Smith, and Schroeder, 2006). Typical surrogate compounds are isotopically labeled, fluorinated, or brominated to distinguish them from other compounds of analytical interest (Maloney, 2005). Surrogate compounds for water samples and POCIS extracts were bisphenol A-d3, caffeine-13C, decafluorobiphenyl, and fluorantehene-d10. Surrogate compounds for wetland sediment samples were 2-fluorobiphenyl, nitrobenzene-D5, p-terphenyl-d14, bisphenol A-d3, decafluorobiphenyl, and fluoranthene-d10. Surrogate recoveries were computed as the ratio of the reported concentration to the spiked concentration, reported as a percentage. Surrogate recoveries were not used to correct reported concentrations in environmental samples.

\section{Occurrence of Organic Wastewater Compounds in Great Marsh}

Ninety-seven OWCs, PAHs and SVOCs were targeted by chemical analysis of the three types of sampling media - discrete water samples, POCIS samples, and wetland sediment samples (table 4). Water-quality data (appendix 1 tables 1-6), passive sampler data (appendix 2 tables 1-2), and wetland sediment quality data (appendix 3 ) are presented and interpreted. Not all compounds were targeted in all sampling media. For the purpose of this discussion, "detection" of a compound includes estimated concentrations reported that are greater than the detection limit but less than the reporting limit, as well as results reported as "presence verified but not quantified." Estimated concentrations between the detection limit and reporting limit are highly variable, and they are used more as a qualitative assessment of the presence of a compound and to a lesser degree as a quantitative indicator of contamination. Hereafter in this report, no distinction is made between estimated and detected concentrations.

\section{Evaluation of Quality-Assurance Data}

The following discussion summarizes data from field quality-control samples and laboratory surrogate spikes associated with analyses of OWCs in discrete water samples, wetland sediment samples, and POCIS water samples. Qualitycontrol data for the OWC concentrations indicated there were few biases caused by artifacts from sampling; however, the high variability and large number of estimated concentrations below the reporting limit indicate that the reported concentration data should be used with caution. Many of the targeted OWCs have been designated by the laboratory as "highly variable compounds" when analyzed with the current method (Maloney, 2005).

OWC concentrations in discrete water samples were compared with eight field-blank samples (appendix table $1-4)$. Seven OWCs were detected in one or more field-blank samples (phenol, tris(2-chloroethyl)phosphate, 4-nonylphenol, 4-tert-octylphenol diethoyxlate, benzophenone, N,N-diethyl-meta-toluamide (DEET), and isophorone). Six of the seven compounds were detected in single field-blank samples. DEET was detected in four of eight field-blank samples. Reported concentrations were low (all were less than $0.1 \mu \mathrm{g} / \mathrm{L}$ ), and generally estimated below the reporting limit. Individual blank-censored values are described in appendix table $1-5$.

Substantially fewer detections were found in the November-December 2011 POCIS field blanks than in the April 2011 field blanks (appendix table 2-1). A field-blank canister was associated with each passive sampler deployed. The majority of the blank detections were common laboratory background contaminants that have been previously identified in POCIS extracts. Bis(2-ethylhexyl) phthalate and diethyl phthalate 
Table 4. Organic wastewater compounds, polycyclic aromatic hydrocarbon compounds, and semivolatile organic compounds targeted by chemical analysis of water and wetland sediment samples collected in and near Great Marsh at Beverly Shores, northwestern Indiana, 2009-11.

[Analytes in shaded entries indicate detection of the compound in at least one sample for at least one sample media (water, POCIS, bed sediment). Bold entries indicate detection of the compound in 50 percent or more of samples for one or more sample media. Information from Zaugg and others, 2002. CAS, Chemical Abstract Service; Kow, octanol-water partition coefficient; $\mu \mathrm{g} / \mathrm{L}$, microgram per liter; POCIS, polar organic chemical integrative sampler; ng/POCIS, nanograms per extract from a POCIS; $\mu \mathrm{g} / \mathrm{kg}$, micrograms per kilogram; n.a., not analyzed in sample; -, no data. Constituent groups: DISINF, disinfectant group, FIRE, flame retardant; FLAV, flavoring; FRAG, fragrance; NID, nonionic detergent; PAH, polycyclic aromatic hydrocarbon, PEST, pesticide group; PHARM, pharmaceutical; SOLV, solvent; SVOC, semivolatile organic compound. Endocrine-disrupting potential: S, suspected; K, known; >, greater than]

\begin{tabular}{|c|c|c|c|c|c|c|c|c|}
\hline $\begin{array}{l}\text { General } \\
\text { use } \\
\text { category }\end{array}$ & Compound name & $\begin{array}{l}\text { Synonyms, abbre- } \\
\text { viations and possible } \\
\text { compound uses or } \\
\text { sources (from Zaugg } \\
\text { and others, 2002) }\end{array}$ & $\begin{array}{l}\text { CAS } \\
\text { registry } \\
\text { number }\end{array}$ & $\log K_{o w}{ }^{2}$ & $\begin{array}{l}\text { Endocrine- } \\
\text { disrupting } \\
\text { potential }\end{array}$ & $\begin{array}{l}\text { Reporting } \\
\text { limit in water } \\
\text { sample, } \\
\text { in } \mu \mathrm{g} / \mathrm{L}\end{array}$ & $\begin{array}{c}\text { Report- } \\
\text { ing limit } \\
\text { in POCIS } \\
\text { extract, } \\
\text { in ng/POCIS }\end{array}$ & $\begin{array}{l}\text { Reporting } \\
\text { limit in bed } \\
\text { sediment } \\
\text { sample, } \\
\text { in } \mu \mathrm{g} / \mathbf{k g}\end{array}$ \\
\hline SOLVENT & 1,2,4-trichlorobenzene & $\begin{array}{l}\text { Used as solvent for } \\
\text { manufacturing of } \\
\text { herbicides, also } \\
\text { degreaser, lubricant }\end{array}$ & $120-82-1$ & 3.93 & - & n.a. & n.a. & 25 \\
\hline PAH & $\begin{array}{l}\text { 1,2-dimethylnaphtha- } \\
\text { lene }\end{array}$ & Fragrance & $573-98-8$ & 4.26 & - & n.a. & n.a. & 25 \\
\hline PEST & 1,4-dichlorobenzene & $\begin{array}{l}\text { Used as moth repellant, } \\
\text { fumigant, deodorant }\end{array}$ & $106-46-7$ & 3.28 & $\mathrm{~S}$ & 0.08 & 64 & 50 \\
\hline PAH & $\begin{array}{l}\text { 1,6-dimethylnaph- } \\
\text { thalene }\end{array}$ & PAH-related compound & $575-43-9$ & 4.26 & - & n.a. & n.a. & 25 \\
\hline PAH & 1-methyl-9H-fluorene & PAH-related compound & $1730-37-6$ & 4.56 & - & n.a. & n.a. & 25 \\
\hline PAH & 1-methylnaphthalene & $\begin{array}{l}\text { Present as } 2-5 \text { percent } \\
\text { of gasoline, diesel } \\
\text { fuel, or crude oil }\end{array}$ & $90-12-0$ & 3.72 & - & 0.04 & 32 & 50 \\
\hline PAH & 1-methylphenanthrene & PAH-related compound & $832-69-9$ & 4.89 & - & n.a. & n.a. & 25 \\
\hline PAH & 1-methylpyrene & PAH-related compound & $2381-21-7$ & 5.48 & - & n.a. & n.a. & 25 \\
\hline FIRE & $\begin{array}{l}\text { 2,2',4,4'-tetrabromodi- } \\
\text { phenylether }\end{array}$ & $\begin{array}{l}\text { Also called PBDE-47; } \\
\text { widely used bromi- } \\
\text { nated flame retardant }\end{array}$ & $5436-43-1$ & 6.77 & - & 0.04 & 34 & 50 \\
\hline PAH & $\begin{array}{l}\text { 2,3,6-trimethylnaph- } \\
\text { thalene }\end{array}$ & PAH-related compound & $829-26-5$ & 4.81 & - & n.a. & n.a. & 25 \\
\hline PAH & $\begin{array}{l}\text { 2,6-dimethylnaph- } \\
\text { thalene }\end{array}$ & $\begin{array}{l}\text { Present in diesel/kero- } \\
\text { sene and as trace in } \\
\text { gasoline }\end{array}$ & $581-42-0$ & 4.26 & - & 0.04 & 32 & 25 \\
\hline PAH & 2-ethylnaphthalene & PAH-related compound & $939-27-5$ & 4.21 & - & n.a. & n.a. & 25 \\
\hline PAH & 2-methylanthracene & PAH-related compound & $613-12-7$ & 4.89 & - & n.a. & n.a. & 25 \\
\hline PAH & 2-methylnaphthalene & $\begin{array}{l}\text { Present as } 2-5 \text { percent } \\
\text { of gasoline, diesel } \\
\text { fuel, or crude oil }\end{array}$ & $91-57-6$ & 3.72 & - & 0.04 & 32 & 50 \\
\hline PEST & $\begin{array}{l}\text { 3,4-dichlorophenyl } \\
\text { isocyanate }\end{array}$ & $\begin{array}{l}\text { Degredate of diuron, a } \\
\text { noncrop herbicide }\end{array}$ & $102-36-3$ & 3.88 & - & 0.32 & 510 & n.a. \\
\hline STEROL & 3-beta-coprostanol & $\begin{array}{l}\text { Also called 5-beta- } \\
\text { cholestan-3-beta-ol; } \\
\text { carnivore fecal } \\
\text { indicator }\end{array}$ & $360-68-9$ & 8.82 & - & 1.6 & 260 & 50 \\
\hline FRAG & 3-methyl-1(H)-indole & $\begin{array}{l}\text { Also called Skatole; } \\
\text { fragrance, stench in } \\
\text { feces and coal tar }\end{array}$ & $83-34-1$ & 2.6 & - & 0.04 & 32 & 50 \\
\hline
\end{tabular}


Table 4. Organic wastewater compounds, polycyclic aromatic hydrocarbon compounds, and semivolatile organic compounds targeted by chemical analysis of water and wetland sediment samples collected in and near Great Marsh at Beverly Shores, northwestern Indiana, 2009-11.-Continued

[Analytes in shaded entries indicate detection of the compound in at least one sample for at least one sample media (water, POCIS, bed sediment). Bold entries indicate detection of the compound in 50 percent or more of samples for one or more sample media. Information from Zaugg and others, 2002. CAS, Chemical Abstract Service; Kow, octanol-water partition coefficient; $\mu \mathrm{g} / \mathrm{L}$, microgram per liter; POCIS, polar organic chemical integrative sampler; ng/POCIS, nanograms per extract from a POCIS; $\mu \mathrm{g} / \mathrm{kg}$, micrograms per kilogram; n.a., not analyzed in sample; -, no data. Constituent groups: DISINF, disinfectant group, FIRE, flame retardant; FLAV, flavoring; FRAG, fragrance; NID, nonionic detergent; PAH, polycyclic aromatic hydrocarbon, PEST, pesticide group; PHARM, pharmaceutical; SOLV, solvent; SVOC, semivolatile organic compound. Endocrine-disrupting potential: S, suspected; K, known; >, greater than]

\begin{tabular}{|c|c|c|c|c|c|c|c|c|}
\hline $\begin{array}{l}\text { General } \\
\text { use } \\
\text { category }\end{array}$ & Compound name & $\begin{array}{l}\text { Synonyms, abbre- } \\
\text { viations and possible } \\
\text { compound uses or } \\
\text { sources (from Zaugg } \\
\text { and others, 2002) }\end{array}$ & $\begin{array}{l}\text { CAS } \\
\text { registry } \\
\text { number }\end{array}$ & $\log K_{o w}{ }^{2}$ & $\begin{array}{c}\text { Endocrine- } \\
\text { disrupting } \\
\text { potential }\end{array}$ & $\begin{array}{l}\text { Reporting } \\
\text { limit in water } \\
\text { sample, } \\
\text { in } \mu g / L\end{array}$ & $\begin{array}{c}\text { Report- } \\
\text { ing limit } \\
\text { in POCIS } \\
\text { extract, } \\
\text { in ng/POCIS }\end{array}$ & $\begin{array}{l}\text { Reporting } \\
\text { limit in bed } \\
\text { sediment } \\
\text { sample, } \\
\text { in } \mu \mathrm{g} / \mathrm{kg}\end{array}$ \\
\hline OTHER & $\begin{array}{l}\text { 3-tert-butyl-4-hydroxy } \\
\text { anisole }\end{array}$ & $\begin{array}{l}\text { Also called BHA; used } \\
\text { as antioxidant, gen- } \\
\text { eral preservative }\end{array}$ & $121-00-6$ & 3.5 & $\mathrm{~K}$ & 0.16 & 130 & 15 \\
\hline NID & 4-cumylphenol & $\begin{array}{l}\text { Nonionic detergent } \\
\text { component or me- } \\
\text { tabolite }\end{array}$ & $599-64-4$ & 4.12 & K & 0.04 & 32 & 50 \\
\hline PAH & $\begin{array}{l}\text { 4H-cyclopenta }[\mathrm{def}] \\
\text { phenanthrene }\end{array}$ & $\begin{array}{l}\text { Also called 4,5-methy- } \\
\text { lenephenanthrene }\end{array}$ & $203-64-5$ & 4.6 & - & n.a. & n.a. & 25 \\
\hline NID & 4-n-octylphenol & $\begin{array}{l}\text { Nonionic detergent } \\
\text { component or me- } \\
\text { tabolite }\end{array}$ & $1806-26-4$ & 5.5 & K & 0.02 & 16 & 50 \\
\hline NID & $\begin{array}{l}\text { 4-nonylphenol (sum of } \\
\text { all isomers) }\end{array}$ & $\begin{array}{l}\text { Also called para-non- } \\
\text { ylphenol; nonionic } \\
\text { detergent component } \\
\text { or metabolite }\end{array}$ & $104-40-5$ & 5.92 & K & 1.6 & n.a. & 75 \\
\hline NID & $\begin{array}{l}\text { 4-nonylphenol } \\
\text { diethoxylate, (sum } \\
\text { of all isomers) }\end{array}$ & $\begin{array}{l}\text { Also called NP2EO } \\
\text { or NPEO2-total; } \\
\text { nonionic detergent } \\
\text { component or me- } \\
\text { tabolite }\end{array}$ & $20427-84-3$ & 5.3 & $\mathrm{~K}$ & 1.6 & 510 & 10 \\
\hline NID & $\begin{array}{l}\text { 4-nonylphenol monoe- } \\
\text { thoxylate, (sum of } \\
\text { all isomers) }\end{array}$ & $\begin{array}{l}\text { Also called NP1EO, } \\
\text { NPEO1-total; deter- } \\
\text { gent component or } \\
\text { metabolite }\end{array}$ & $104-35-8$ & 5.58 & $\mathrm{~K}$ & 1.6 & 260 & 50 \\
\hline NID & 4-tert-octylphenol & $\begin{array}{l}\text { Nonionic detergent } \\
\text { component or me- } \\
\text { tabolite }\end{array}$ & $140-66-9$ & 5.28 & $\mathrm{~K}$ & 0.4 & 16 & 50 \\
\hline NID & $\begin{array}{l}\text { 4-tert-octylphenol } \\
\text { diethoxylate }\end{array}$ & $\begin{array}{l}\text { Also called OPEO2; } \\
\text { nonionic detergent } \\
\text { component or me- } \\
\text { tabolite }\end{array}$ & $2315-61-9$ & 4.59 & $\mathrm{~K}$ & 0.2 & 44 & 50 \\
\hline NID & $\begin{array}{l}\text { 4-tert-octylphenol } \\
\text { monoethoxylate }\end{array}$ & $\begin{array}{l}\text { Also called OP1EO, } \\
\text { OPEO1; detergent } \\
\text { compound }\end{array}$ & $2315-67-5$ & 4.97 & $\mathrm{~K}$ & 0.6 & 16 & 25 \\
\hline OTHER & $\begin{array}{l}\text { 5-methyl-1H-benzo- } \\
\text { triazole }\end{array}$ & $\begin{array}{l}\text { Used as antioxidant } \\
\text { in antifreeze and } \\
\text { deicers }\end{array}$ & $136-85-6$ & 1.71 & - & 0.32 & 260 & n.a. \\
\hline
\end{tabular}


Table 4. Organic wastewater compounds, polycyclic aromatic hydrocarbon compounds, and semivolatile organic compounds targeted by chemical analysis of water and wetland sediment samples collected in and near Great Marsh at Beverly Shores, northwestern Indiana, 2009-11.-Continued

[Analytes in shaded entries indicate detection of the compound in at least one sample for at least one sample media (water, POCIS, bed sediment). Bold entries indicate detection of the compound in 50 percent or more of samples for one or more sample media. Information from Zaugg and others, 2002. CAS, Chemical Abstract Service; Kow, octanol-water partition coefficient; $\mu \mathrm{g} / \mathrm{L}$, microgram per liter; POCIS, polar organic chemical integrative sampler; ng/POCIS, nanograms per extract from a POCIS; $\mu \mathrm{g} / \mathrm{kg}$, micrograms per kilogram; n.a., not analyzed in sample; -, no data. Constituent groups: DISINF, disinfectant group, FIRE, flame retardant; FLAV, flavoring; FRAG, fragrance; NID, nonionic detergent; PAH, polycyclic aromatic hydrocarbon, PEST, pesticide group; PHARM, pharmaceutical; SOLV, solvent; SVOC, semivolatile organic compound. Endocrine-disrupting potential: S, suspected; K, known; >, greater than]

\begin{tabular}{|c|c|c|c|c|c|c|c|c|}
\hline $\begin{array}{l}\text { General } \\
\text { use } \\
\text { category }\end{array}$ & Compound name & $\begin{array}{l}\text { Synonyms, abbre- } \\
\text { viations and possible } \\
\text { compound uses or } \\
\text { sources (from Zaugg } \\
\text { and others, 2002) }\end{array}$ & $\begin{array}{c}\text { CAS } \\
\text { registry } \\
\text { number }^{1}\end{array}$ & $\log K_{o w}{ }^{2}$ & $\begin{array}{c}\text { Endocrine- } \\
\text { disrupting } \\
\text { potential }\end{array}$ & $\begin{array}{l}\text { Reporting } \\
\text { limit in water } \\
\text { sample, } \\
\text { in } \mu \mathrm{g} / \mathrm{L}\end{array}$ & $\begin{array}{c}\text { Report- } \\
\text { ing limit } \\
\text { in POCIS } \\
\text { extract, } \\
\text { in ng/POCIS }\end{array}$ & $\begin{array}{l}\text { Reporting } \\
\text { limit in bed } \\
\text { sediment } \\
\text { sample, } \\
\text { in } \mu \mathrm{g} / \mathrm{kg}\end{array}$ \\
\hline PAH & Acenaphthene & $\begin{array}{l}\text { PAH compound used } \\
\text { in manufactur- } \\
\text { ing dyes, plastics, } \\
\text { pesticides. Found in } \\
\text { automobile exhaust, } \\
\text { wood preservatives, } \\
\text { and cigarette smoke }\end{array}$ & $83-32-9$ & 4.15 & - & n.a. & n.a. & 25 \\
\hline PAH & Acenaphthylene & $\begin{array}{l}\text { PAH compound that } \\
\text { is a component of } \\
\text { coal tar }\end{array}$ & $208-96-8$ & 3.94 & - & n.a. & n.a. & 25 \\
\hline FRAG & Acetophenone & $\begin{array}{l}\text { Fragrance in detergent } \\
\text { and tobacco, used as } \\
\text { flavor in beverages }\end{array}$ & $98-86-2$ & 1.67 & - & 0.4 & 64 & 15 \\
\hline FRAG & $\begin{array}{l}\text { Acetyl hexamethyl tet- } \\
\text { rahydronaphthalene }\end{array}$ & $\begin{array}{l}\text { Also called tonalide } \\
\text { and AHTN; musk } \\
\text { fragrance, persis- } \\
\text { tent, widespread in } \\
\text { groundwater, con- } \\
\text { cern for bioaccumu- } \\
\text { lation and toxicity }\end{array}$ & $21145-77-7$ & 6.35 & - & 0.04 & 32 & 50 \\
\hline PAH & Anthracene & $\begin{array}{l}\text { PAH compound that is } \\
\text { a component of tar, } \\
\text { diesel, or crude oil, } \\
\text { and is a combustion } \\
\text { product }\end{array}$ & $120-12-7$ & 4.35 & - & 0.02 & 16 & 25 \\
\hline PEST & Anthraquinone & $\begin{array}{l}\text { Manufacturing dye/tex- } \\
\text { tiles, seed treatment, } \\
\text { bird repellent }\end{array}$ & $84-65-1$ & 3.34 & - & 0.04 & 32 & 25 \\
\hline PEST & Atrazine & $\begin{array}{l}\text { Selective triazine } \\
\text { herbicide }\end{array}$ & $1912-24-9$ & 2.82 & K & 0.16 & 130 & 10 \\
\hline PAH & Benz[a]anthracene & $\begin{array}{l}\text { PAH compound that } \\
\text { is a combustion } \\
\text { product }\end{array}$ & $56-55-3$ & 5.52 & - & n.a. & n.a. & 25 \\
\hline PAH & Benzo[a]pyrene & $\begin{array}{l}\text { PAH compound that } \\
\text { is used in cancer } \\
\text { research and is a } \\
\text { combustion product }\end{array}$ & $50-32-8$ & 6.11 & K & 0.02 & 16 & 25 \\
\hline PAH & Benzo[b]fluoranthene & $\begin{array}{l}\text { PAH compound that } \\
\text { is a combustion } \\
\text { product }\end{array}$ & $205-99-2$ & 6.11 & - & n.a. & n.a. & 25 \\
\hline
\end{tabular}


Table 4. Organic wastewater compounds, polycyclic aromatic hydrocarbon compounds, and semivolatile organic compounds targeted by chemical analysis of water and wetland sediment samples collected in and near Great Marsh at Beverly Shores, northwestern Indiana, 2009-11.-Continued

[Analytes in shaded entries indicate detection of the compound in at least one sample for at least one sample media (water, POCIS, bed sediment). Bold entries indicate detection of the compound in 50 percent or more of samples for one or more sample media. Information from Zaugg and others, 2002. CAS, Chemical Abstract Service; Kow, octanol-water partition coefficient; $\mu \mathrm{g} / \mathrm{L}$, microgram per liter; POCIS, polar organic chemical integrative sampler; ng/POCIS, nanograms per extract from a POCIS; $\mu \mathrm{g} / \mathrm{kg}$, micrograms per kilogram; n.a., not analyzed in sample; -, no data. Constituent groups: DISINF, disinfectant group, FIRE, flame retardant; FLAV, flavoring; FRAG, fragrance; NID, nonionic detergent; PAH, polycyclic aromatic hydrocarbon, PEST, pesticide group; PHARM, pharmaceutical; SOLV, solvent; SVOC, semivolatile organic compound. Endocrine-disrupting potential: S, suspected; K, known; >, greater than]

\begin{tabular}{|c|c|c|c|c|c|c|c|c|}
\hline $\begin{array}{l}\text { General } \\
\text { use } \\
\text { category }\end{array}$ & Compound name & $\begin{array}{l}\text { Synonyms, abbre- } \\
\text { viations and possible } \\
\text { compound uses or } \\
\text { sources (from Zaugg } \\
\text { and others, 2002) }\end{array}$ & $\begin{array}{l}\text { CAS } \\
\text { registry } \\
\text { number }\end{array}$ & $\log K_{o w}{ }^{2}$ & $\begin{array}{c}\text { Endocrine- } \\
\text { disrupting } \\
\text { potential }\end{array}$ & $\begin{array}{c}\text { Reporting } \\
\text { limit in water } \\
\text { sample, } \\
\text { in } \mu \mathrm{g} / \mathrm{L}\end{array}$ & $\begin{array}{c}\text { Report- } \\
\text { ing limit } \\
\text { in POCIS } \\
\text { extract, } \\
\text { in ng/POCIS }\end{array}$ & $\begin{array}{c}\text { Reporting } \\
\text { limit in bed } \\
\text { sediment } \\
\text { sample, } \\
\text { in } \mu \mathrm{g} / \mathrm{kg}\end{array}$ \\
\hline PAH & Benzo[e]pyrene & $\begin{array}{l}\text { PAH compound that } \\
\text { is a component of } \\
\text { coal tar }\end{array}$ & $192-97-2$ & 6.11 & - & n.a. & n.a. & 25 \\
\hline PAH & Benzo[ghi]perylene & $\begin{array}{l}\text { PAH compound that is } \\
\text { found in automotive } \\
\text { emissions and as a } \\
\text { combustion product }\end{array}$ & $191-24-2$ & 6.70 & - & n.a. & n.a. & 25 \\
\hline PAH & Benzo[k]fluoranthene & $\begin{array}{l}\text { PAH compound that is } \\
\text { found in automotive } \\
\text { emissions and as a } \\
\text { combustion product }\end{array}$ & $207-08-9$ & 6.11 & - & n.a. & n.a. & 25 \\
\hline OTHER & Benzophenone & $\begin{array}{l}\text { Used as fixative for } \\
\text { perfumes and soaps }\end{array}$ & $119-61-9$ & 3.15 & S & 0.08 & 64 & 50 \\
\hline STEROL & Beta-sitosterol & Plant sterol & $83-46-5$ & 9.65 & - & 4.8 & 510 & 50 \\
\hline STEROL & Beta-stigmastanol & $\begin{array}{l}\text { Also called stigmasta- } \\
\text { nol; herbivore fecal } \\
\text { indicator (digestion } \\
\text { of sitosterol) }\end{array}$ & $19466-47-8$ & 9.73 & - & 3.4 & 260 & 50 \\
\hline PLAS & $\begin{array}{l}\text { Bis(2-ethylhexyl) } \\
\text { phthalate }\end{array}$ & $\begin{array}{l}\text { Also called diethyl- } \\
\text { hexyl phthalate }\end{array}$ & $117-81-7$ & 8.39 & $\mathrm{~K}$ & 2 & 32 & 25 \\
\hline PLAS & Bisphenol A & $\begin{array}{l}\text { Used to manufacture } \\
\text { polycarbonate res- } \\
\text { ins, also antioxidant, } \\
\text { flame retardant }\end{array}$ & $80-05-7$ & 3.64 & K & 0.04 & 32 & 50 \\
\hline PEST & Bromacil & $\begin{array}{l}\text { Herbicide, general use } \\
\text { pesticide, }>80 \text { per- } \\
\text { cent noncrop usage } \\
\text { on grass/brush }\end{array}$ & $314-40-9$ & 1.68 & - & 0.16 & 130 & 50 \\
\hline PHARM & Caffeine & $\begin{array}{l}\text { Beverages, diruretic, } \\
\text { very mobile/biode- } \\
\text { gradable }\end{array}$ & $58-08-2$ & 0.16 & - & 0.08 & 64 & n.a. \\
\hline FLAV & Camphor & $\begin{array}{l}\text { Used as flavor, odor- } \\
\text { ant, and in ointments }\end{array}$ & $76-22-2$ & 3.04 & - & 0.08 & 64 & 50 \\
\hline PEST & Carbaryl & $\begin{array}{l}\text { Insecticide, crop and } \\
\text { garden usage, low } \\
\text { persistance }\end{array}$ & $63-25-2$ & 2.35 & K & 0.06 & 64 & n.a. \\
\hline PEST & Carbazole & $\begin{array}{l}\text { Insecticide, manufac- } \\
\text { turing dyes, explo- } \\
\text { sives and lubricants }\end{array}$ & $86-74-8$ & 3.23 & - & 0.02 & 32 & 25 \\
\hline
\end{tabular}


Table 4. Organic wastewater compounds, polycyclic aromatic hydrocarbon compounds, and semivolatile organic compounds targeted by chemical analysis of water and wetland sediment samples collected in and near Great Marsh at Beverly Shores, northwestern Indiana, 2009-11.-Continued

[Analytes in shaded entries indicate detection of the compound in at least one sample for at least one sample media (water, POCIS, bed sediment). Bold entries indicate detection of the compound in 50 percent or more of samples for one or more sample media. Information from Zaugg and others, 2002. CAS, Chemical Abstract Service; Kow, octanol-water partition coefficient; $\mu \mathrm{g} / \mathrm{L}$, microgram per liter; POCIS, polar organic chemical integrative sampler; ng/POCIS, nanograms per extract from a POCIS; $\mu \mathrm{g} / \mathrm{kg}$, micrograms per kilogram; n.a., not analyzed in sample; -, no data. Constituent groups: DISINF, disinfectant group, FIRE, flame retardant; FLAV, flavoring; FRAG, fragrance; NID, nonionic detergent; PAH, polycyclic aromatic hydrocarbon, PEST, pesticide group; PHARM, pharmaceutical; SOLV, solvent; SVOC, semivolatile organic compound. Endocrine-disrupting potential: S, suspected; K, known; >, greater than]

\begin{tabular}{|c|c|c|c|c|c|c|c|c|}
\hline $\begin{array}{l}\text { General } \\
\text { use } \\
\text { category }\end{array}$ & Compound name & $\begin{array}{l}\text { Synonyms, abbre- } \\
\text { viations and possible } \\
\text { compound uses or } \\
\text { sources (from Zaugg } \\
\text { and others, 2002) }\end{array}$ & $\begin{array}{l}\text { CAS } \\
\text { registry } \\
\text { number }^{1}\end{array}$ & $\log K_{o w}{ }^{2}$ & $\begin{array}{l}\text { Endocrine- } \\
\text { disrupting } \\
\text { potential }\end{array}$ & $\begin{array}{l}\text { Reporting } \\
\text { limit in water } \\
\text { sample, } \\
\text { in } \mu \mathrm{g} / \mathrm{L}\end{array}$ & $\begin{array}{c}\text { Report- } \\
\text { ing limit } \\
\text { in POCIS } \\
\text { extract, } \\
\text { in ng/POCIS }\end{array}$ & $\begin{array}{c}\text { Reporting } \\
\text { limit in bed } \\
\text { sediment } \\
\text { sample, } \\
\text { in } \mu \mathrm{g} / \mathrm{kg}\end{array}$ \\
\hline PEST & Chlorpyrifos & $\begin{array}{l}\text { Insecticide, domestic } \\
\text { pest and termite } \\
\text { control (domestic } \\
\text { use restricted as of } \\
\text { 2001) }\end{array}$ & $2921-88-2$ & 4.66 & $\mathrm{~K}$ & 0.12 & 260 & 50 \\
\hline STEROL & Cholesterol & $\begin{array}{l}\text { Often a fecal indicator, } \\
\text { also a plant sterol }\end{array}$ & $57-88-5$ & 8.74 & - & 1.6 & 260 & 25 \\
\hline PAH & Chrysene & $\begin{array}{l}\text { PAH compound that } \\
\text { is a combustion } \\
\text { product (http://www. } \\
\text { nature.nps.gov/ } \\
\text { hazardssafety/toxic/ } \\
\text { chrysene.pdf) }\end{array}$ & $218-01-9$ & 5.52 & - & n.a. & n.a. & 25 \\
\hline PHARM & Cotinine & $\begin{array}{l}\text { Primary nicotine me- } \\
\text { tabolite }\end{array}$ & $486-56-6$ & 0.34 & - & 0.08 & 64 & n.a. \\
\hline PEST & Diazinon & $\begin{array}{l}\text { Insecticide with } 40 \\
\text { percent or more } \\
\text { nonagricultural us- } \\
\text { age, control of ants } \\
\text { and flies }\end{array}$ & $333-41-5$ & 3.86 & K & 0.32 & 260 & 50 \\
\hline PAH & Dibenz[a,h]anthracene & $\begin{array}{l}\text { PAH compound that } \\
\text { is a component of } \\
\text { coal tar }\end{array}$ & $53-70-3$ & 6.7 & - & n.a. & n.a. & 25 \\
\hline SVOC & Dibenzothiophene & $\begin{array}{l}\text { Component of petro- } \\
\text { leum (http://www. } \\
\text { nature.nps.gov/ } \\
\text { hazardssafety/toxic/ } \\
\text { dibenzot.pdf) }\end{array}$ & $132-65-0$ & 4.17 & - & n.a. & n.a. & 25 \\
\hline PEST & Dichlorvos & $\begin{array}{l}\text { Insecticide, pet collars, } \\
\text { also naled or trichlo- } \\
\text { fon degredate }\end{array}$ & $62-73-7$ & 0.6 & S & 0.08 & 64 & n.a. \\
\hline PLAS & Diethyl phthalate & $\begin{array}{l}\text { Also called DEP; plas- } \\
\text { ticizer for polymers } \\
\text { and resins }\end{array}$ & $84-66-2$ & 2.82 & $\mathrm{~K}$ & 0.4 & 32 & 25 \\
\hline FRAG & d-limonene & $\begin{array}{l}\text { Used as fungicide, an- } \\
\text { timicrobial, antiviral, } \\
\text { fragrance in aerosols }\end{array}$ & $5989-27-5$ & 4.83 & - & 0.16 & 130 & 50 \\
\hline
\end{tabular}


Table 4. Organic wastewater compounds, polycyclic aromatic hydrocarbon compounds, and semivolatile organic compounds targeted by chemical analysis of water and wetland sediment samples collected in and near Great Marsh at Beverly Shores, northwestern Indiana, 2009-11.-Continued

[Analytes in shaded entries indicate detection of the compound in at least one sample for at least one sample media (water, POCIS, bed sediment). Bold entries indicate detection of the compound in 50 percent or more of samples for one or more sample media. Information from Zaugg and others, 2002. CAS, Chemical Abstract Service; Kow, octanol-water partition coefficient; $\mu \mathrm{g} / \mathrm{L}$, microgram per liter; POCIS, polar organic chemical integrative sampler; ng/POCIS, nanograms per extract from a POCIS; $\mu \mathrm{g} / \mathrm{kg}$, micrograms per kilogram; n.a., not analyzed in sample; -, no data. Constituent groups: DISINF, disinfectant group, FIRE, flame retardant; FLAV, flavoring; FRAG, fragrance; NID, nonionic detergent; PAH, polycyclic aromatic hydrocarbon, PEST, pesticide group; PHARM, pharmaceutical; SOLV, solvent; SVOC, semivolatile organic compound. Endocrine-disrupting potential: S, suspected; K, known; >, greater than]

\begin{tabular}{|c|c|c|c|c|c|c|c|c|}
\hline $\begin{array}{l}\text { General } \\
\text { use } \\
\text { category }\end{array}$ & Compound name & $\begin{array}{l}\text { Synonyms, abbre- } \\
\text { viations and possible } \\
\text { compound uses or } \\
\text { sources (from Zaugg } \\
\text { and others, 2002) }\end{array}$ & $\begin{array}{l}\text { CAS } \\
\text { registry } \\
\text { number }\end{array}$ & $\log K_{o w}{ }^{2}$ & $\begin{array}{l}\text { Endocrine- } \\
\text { disrupting } \\
\text { potential }\end{array}$ & $\begin{array}{l}\text { Reporting } \\
\text { limit in water } \\
\text { sample, } \\
\text { in } \mu \mathrm{g} / \mathrm{L}\end{array}$ & $\begin{array}{c}\text { Report- } \\
\text { ing limit } \\
\text { in POCIS } \\
\text { extract, } \\
\text { in ng/POCIS }\end{array}$ & $\begin{array}{l}\text { Reporting } \\
\text { limit in bed } \\
\text { sediment } \\
\text { sample, } \\
\text { in } \mu \mathrm{g} / \mathrm{kg}\end{array}$ \\
\hline PAH & Fluoranthene & $\begin{array}{l}\text { PAH compound that is } \\
\text { a component of coal } \\
\text { tar and asphalt, (only } \\
\text { traces in gasoline or } \\
\text { diesel fuel) and is } \\
\text { also a combustion } \\
\text { product }\end{array}$ & $206-44-0$ & 4.93 & - & 0.02 & 16 & 25 \\
\hline PAH & Fluorene & $\begin{array}{l}\text { PAH compound that } \\
\text { is a component of } \\
\text { coal tar }\end{array}$ & $86-73-7$ & 4.02 & - & n.a. & n.a. & 25 \\
\hline PEST & Hexachlorobenzene & Fungicide & $118-74-1$ & 5.86 & - & n.a. & n.a. & 25 \\
\hline FRAG & $\begin{array}{l}\text { Hexahydrohexameth- } \\
\text { ylcyclopentabenzo- } \\
\text { pyran }\end{array}$ & $\begin{array}{l}\text { Also called HHCB and } \\
\text { galaxolide; musk } \\
\text { fragrance, persis- } \\
\text { tent, widespread in } \\
\text { groundwater, con- } \\
\text { cern for bioaccumu- } \\
\text { lation and toxicity }\end{array}$ & $1222-05-5$ & 6.26 & - & 0.04 & 32 & 50 \\
\hline PAH & $\begin{array}{l}\text { Indeno[1,2,3-cd] } \\
\text { pyrene }\end{array}$ & $\begin{array}{l}\text { PAH compound that is } \\
\text { found in automotive } \\
\text { emissions and is a } \\
\text { combustion product }\end{array}$ & $193-39-5$ & 6.7 & - & n.a. & n.a. & 25 \\
\hline FRAG & Indole & $\begin{array}{l}\text { Used as pesticide inert } \\
\text { ingredient, also fra- } \\
\text { grance in coffee }\end{array}$ & $120-72-9$ & 2.05 & - & 0.04 & 32 & 10 \\
\hline FRAG & Isoborneol & $\begin{array}{l}\text { Used as fragrance in } \\
\text { perfumery, in disin- } \\
\text { fectants }\end{array}$ & $124-76-5$ & 2.85 & - & 0.09 & 64 & 50 \\
\hline SOLV & Isophorone & $\begin{array}{l}\text { Used as solvent for } \\
\text { lacquer, plastic, oil, } \\
\text { silicone, resin }\end{array}$ & $78-59-1$ & 2.62 & - & 0.05 & 32 & 50 \\
\hline SOLV & Isopropylbenzene & $\begin{array}{l}\text { Also called cumene; } \\
\text { used in manufactur- } \\
\text { ing of phenol and } \\
\text { acetone, fuels and } \\
\text { paint thinner }\end{array}$ & $98-82-8$ & 3.45 & - & 0.04 & 32 & 10 \\
\hline FLAV & Isoquinoline & $\begin{array}{l}\text { Used in flavors and } \\
\text { fragrances }\end{array}$ & $119-65-3$ & 2.14 & - & 0.04 & 32 & 10 \\
\hline FLAV & Menthol & $\begin{array}{l}\text { Used in cigarettes, } \\
\text { cough drops, lini- } \\
\text { ment, mouthwash }\end{array}$ & $89-78-1$ & 3.38 & - & 0.32 & 260 & 50 \\
\hline
\end{tabular}


Table 4. Organic wastewater compounds, polycyclic aromatic hydrocarbon compounds, and semivolatile organic compounds targeted by chemical analysis of water and wetland sediment samples collected in and near Great Marsh at Beverly Shores, northwestern Indiana, 2009-11.-Continued

[Analytes in shaded entries indicate detection of the compound in at least one sample for at least one sample media (water, POCIS, bed sediment). Bold entries indicate detection of the compound in 50 percent or more of samples for one or more sample media. Information from Zaugg and others, 2002. CAS, Chemical Abstract Service; Kow, octanol-water partition coefficient; $\mu \mathrm{g} / \mathrm{L}$, microgram per liter; POCIS, polar organic chemical integrative sampler; ng/POCIS, nanograms per extract from a POCIS; $\mu \mathrm{g} / \mathrm{kg}$, micrograms per kilogram; n.a., not analyzed in sample; -, no data. Constituent groups: DISINF, disinfectant group, FIRE, flame retardant; FLAV, flavoring; FRAG, fragrance; NID, nonionic detergent; PAH, polycyclic aromatic hydrocarbon, PEST, pesticide group; PHARM, pharmaceutical; SOLV, solvent; SVOC, semivolatile organic compound. Endocrine-disrupting potential: S, suspected; K, known; >, greater than]

\begin{tabular}{|c|c|c|c|c|c|c|c|c|}
\hline $\begin{array}{l}\text { General } \\
\text { use } \\
\text { category }\end{array}$ & Compound name & $\begin{array}{l}\text { Synonyms, abbre- } \\
\text { viations and possible } \\
\text { compound uses or } \\
\text { sources (from Zaugg } \\
\text { and others, 2002) }\end{array}$ & $\begin{array}{l}\text { CAS } \\
\text { registry } \\
\text { number }\end{array}$ & $\log K_{o w}^{2}$ & $\begin{array}{l}\text { Endocrine- } \\
\text { disrupting } \\
\text { potential }\end{array}$ & $\begin{array}{l}\text { Reporting } \\
\text { limit in water } \\
\text { sample, } \\
\text { in } \mu \mathrm{g} / \mathrm{L}\end{array}$ & $\begin{array}{c}\text { Report- } \\
\text { ing limit } \\
\text { in POCIS } \\
\text { extract, } \\
\text { in ng/POCIS }\end{array}$ & $\begin{array}{l}\text { Reporting } \\
\text { limit in bed } \\
\text { sediment } \\
\text { sample, } \\
\text { in } \mu \mathrm{g} / \mathrm{kg}\end{array}$ \\
\hline PEST & Metalaxyl & $\begin{array}{l}\text { Herbicide, fungicide, } \\
\text { general use pesti- } \\
\text { cide, mildew, blight, } \\
\text { pathogens, golf/turf }\end{array}$ & $57837-19-1$ & 1.7 & - & 0.16 & 130 & n.a. \\
\hline OTHER & Methyl salicylate & $\begin{array}{l}\text { Used as liniment, and } \\
\text { in food, beverages, } \\
\text { and UV-absorbing } \\
\text { lotion }\end{array}$ & $119-36-8$ & 2.6 & - & 0.08 & 64 & n.a. \\
\hline PEST & Metolachlor & $\begin{array}{l}\text { Herbicide, general use } \\
\text { pesticide, indica- } \\
\text { tor of agricultural } \\
\text { drainage }\end{array}$ & $51218-45-2$ & 3.24 & - & 0.04 & 32 & 50 \\
\hline PEST & $\begin{array}{l}\text { N,N-diethyl-meta- } \\
\text { toluamide (DEET) }\end{array}$ & $\begin{array}{l}\text { Also called DEET; } \\
\text { insecticide, urban } \\
\text { uses, mosquito } \\
\text { repellant }\end{array}$ & $134-62-3$ & 2.26 & - & 0.04 & 32 & 10 \\
\hline PAH & Naphthalene & $\begin{array}{l}\text { Used as fumigant, } \\
\text { moth repellant, } \\
\text { major component of } \\
\text { gasoline }\end{array}$ & $91-20-3$ & 3.17 & - & 0.02 & 16 & 25 \\
\hline NID & $\begin{array}{l}\text { Para-nonylphenol } \\
\text { (total) (branched) }\end{array}$ & $\begin{array}{l}\text { Nonionic detergent } \\
\text { component }\end{array}$ & $84852-15-3$ & 5.77 & $\mathrm{~K}$ & 1.6 & 230 & n.a. \\
\hline OTHER & $p$-cresol & $\begin{array}{l}\text { Also called para-cresol } \\
\text { or 4-methyl phenol; } \\
\text { used as wood preser- } \\
\text { vative, disinfectant }\end{array}$ & $106-44-5$ & 2.06 & - & 0.08 & 64 & 25 \\
\hline PEST & Pentachloroanisole & $\begin{array}{l}\text { Degredation product of } \\
\text { pentachlorophenol } \\
\text { and pentachloroni- } \\
\text { trobenzene }\end{array}$ & $1825-21-4$ & 5.3 & - & n.a. & n.a. & 25 \\
\hline PEST & $\begin{array}{l}\text { Pentachloronitroben- } \\
\text { zene }\end{array}$ & Fungicide & $82-68-8$ & 5.03 & - & n.a. & n.a. & 25 \\
\hline PEST & Pentachlorophenol & $\begin{array}{l}\text { Herbicide, fungicide, } \\
\text { disinfectant, wood } \\
\text { preservative, termite } \\
\text { control }\end{array}$ & $87-86-5$ & 4.74 & S & 1.6 & 260 & n.a. \\
\hline PAH & Perylene & Fluorescent dye & $198-55-0$ & 6.11 & - & n.a. & n.a. & 25 \\
\hline
\end{tabular}


Table 4. Organic wastewater compounds, polycyclic aromatic hydrocarbon compounds, and semivolatile organic compounds targeted by chemical analysis of water and wetland sediment samples collected in and near Great Marsh at Beverly Shores, northwestern Indiana, 2009-11.-Continued

[Analytes in shaded entries indicate detection of the compound in at least one sample for at least one sample media (water, POCIS, bed sediment). Bold entries indicate detection of the compound in 50 percent or more of samples for one or more sample media. Information from Zaugg and others, 2002. CAS, Chemical Abstract Service; Kow, octanol-water partition coefficient; $\mu \mathrm{g} / \mathrm{L}$, microgram per liter; POCIS, polar organic chemical integrative sampler; ng/POCIS, nanograms per extract from a POCIS; $\mu \mathrm{g} / \mathrm{kg}$, micrograms per kilogram; n.a., not analyzed in sample; -, no data. Constituent groups: DISINF, disinfectant group, FIRE, flame retardant; FLAV, flavoring; FRAG, fragrance; NID, nonionic detergent; PAH, polycyclic aromatic hydrocarbon, PEST, pesticide group; PHARM, pharmaceutical; SOLV, solvent; SVOC, semivolatile organic compound. Endocrine-disrupting potential: S, suspected; K, known; >, greater than]

\begin{tabular}{|c|c|c|c|c|c|c|c|c|}
\hline $\begin{array}{l}\text { General } \\
\text { use } \\
\text { category }\end{array}$ & Compound name & $\begin{array}{l}\text { Synonyms, abbre- } \\
\text { viations and possible } \\
\text { compound uses or } \\
\text { sources (from Zaugg } \\
\text { and others, 2002) }\end{array}$ & $\begin{array}{l}\text { CAS } \\
\text { registry } \\
\text { number }^{1}\end{array}$ & $\log K_{o w}{ }^{2}$ & $\begin{array}{c}\text { Endocrine- } \\
\text { disrupting } \\
\text { potential }\end{array}$ & $\begin{array}{c}\text { Reporting } \\
\text { limit in water } \\
\text { sample, } \\
\text { in } \mu \mathrm{g} / \mathrm{L}\end{array}$ & $\begin{array}{c}\text { Report- } \\
\text { ing limit } \\
\text { in POCIS } \\
\text { extract, } \\
\text { in ng/POCIS }\end{array}$ & $\begin{array}{c}\text { Reporting } \\
\text { limit in bed } \\
\text { sediment } \\
\text { sample, } \\
\text { in } \mu \mathrm{g} / \mathrm{kg}\end{array}$ \\
\hline PAH & Phenanthrene & $\begin{array}{l}\text { PAH compound that is } \\
\text { used in manufactur- } \\
\text { ing explosives and } \\
\text { is a component of } \\
\text { tar, diesel fuel, and } \\
\text { crude oil and as a } \\
\text { combustion product }\end{array}$ & $85-01-8$ & 4.35 & - & 0.02 & 16 & 25 \\
\hline SVOC & Phenanthridine & Used as fluorescent dye & $229-87-8$ & 3.32 & - & n.a. & n.a. & 25 \\
\hline DISINF & Phenol & $\begin{array}{l}\text { Used as disinfectant, } \\
\text { manufacturing of } \\
\text { several products, } \\
\text { found in leachate }\end{array}$ & $108-95-2$ & 1.51 & - & 0.16 & 64 & 50 \\
\hline PEST & Prometon & $\begin{array}{l}\text { Herbicide (noncrop } \\
\text { only), applied prior } \\
\text { to blacktop }\end{array}$ & $1610-18-0$ & 3.57 & - & 0.16 & 130 & 50 \\
\hline PAH & Pyrene & $\begin{array}{l}\text { PAH compound that is } \\
\text { a component of coal } \\
\text { tar and asphalt (only } \\
\text { traces in gasoline or } \\
\text { diesel fuel) and is a } \\
\text { combustion product }\end{array}$ & $129-00-0$ & 4.93 & - & 0.02 & 16 & 25 \\
\hline
\end{tabular}

${ }^{1}$ CAS Registry Number ${ }^{\mathbb{B}}$ is a Registered Trademark of the American Chemical Society. CAS recommends the verification of the CASRNs through CAS Client Services.

${ }^{2}$ Log Kow calculated using exposure assessment tools and models from the U.S. Environmental Protection Agency (The Estimation Programs Interface (EPI) SuiteTM KOWWINTM Software, version 1.68; U.S. Environmental Protection Agency, 2010).

were detected in all POCIS field and fabrication blanks. Phthalates, naphthalenes, phenanthrene, and cholesterol were found in all POCIS blanks. Acetophenone, d-limonene, benzophenone, and 1,4-dichlorobenzene were occasionally found as common laboratory contaminants and were present in POCIS blanks from the April 2011 deployment. Concentrations of acetophenone, d-limonene, benzophenone, and 1,4-dichlorobenzene detected in the April 2011 field deployed samples were from about 1.3 to 8 times higher than concentrations measured in the field deployed blanks and from about 1.4 to 11 times higher than in the laboratory blank analyzed with the April 2011 samples. These ratios were computed by dividing the uncorrected concentrations from environmental samples by either the paired field blank concentration or the lab blank analyzed with the samples. Uncorrected concentrations from environmental samples were computed as the sum of the environmental concentrations in table 6 and field blank concentrations in appendix table $2-1$.

All data presented for POCIS samples have been blank corrected by subtracting the concentrations of compounds detected in the associated field blanks. If a compound was detected at a larger concentration in the field blank than in the environmental sample, the resulting values are reported as "not detected."

One replicate water sample was collected with each set of discrete water samples. RPD was calculated for compounds detected in both environmental and replicate samples. RPDs for organic wastewater compounds ranged from zero to 133 
percent, with a median RPD of 22 percent (appendix table 1-6). The high variability and large number of estimated concentrations below the reporting limit emphasize that the reported concentration data should be used with an understanding of its variability. For each deployment of passive samplers, one replicate POCIS was deployed. Replication of the duplicate POCIS was generally good, with values within a factor of 2 (appendix table 2-1). Considering these concentrations were from POCIS in separate deployment canisters that were exposed to slightly different flow and exposure conditions over an extended period of time, a factor of 2 was considered acceptable. One concurrent replicate wetland sediment sample was collected at site W3. RPDs of the six surrogate compounds agreed within 38 percent between the environmental and replicate samples. RPDs of reported and estimated concentrations of OWCs and PAHs ranged from zero to 40 percent, with a median RPD of 14 percent (appendix table 3-1).

Recoveries of surrogate compounds from laboratory spiked samples were highly variable. Median recoveries of the four surrogates ranged from 51 to 88 percent for discrete water samples (appendix table 1-2) and from 90 to 116 percent for POCIS sample extracts. Surrogate recoveries from sediment samples were also highly variable - median recoveries of the six surrogate standards ranged from 15 to 75 percent (appendix table 3-1).

\section{Organic Wastewater Compounds in Discrete Water Samples}

Discrete water samples and passive sampler extracts were analyzed for 69 OWCs, and a total of 52 were detected in discrete water samples at 1 or more sites (appendix table 1-2). The seven OWCs detected in more than 50 percent of the discrete water samples were (in order of decreasing detection) cholesterol, beta-sitosterol, indole, p-cresol, camphor, beta-stigmastanol, and isophorone (table 5). Other compounds detected in more than 30 percent of samples from a given site type were 3-methyl-1H-indole, DEET, pyrene, fluoranthene, phenanthrene, 3-beta-coprostanol, benzo[a]pyrene, 4-nonylphenol diethoxylate, anthracene, and pentachlorophenol (table 5). Six of 53 compounds were detected at concentrations greater than $2.1 \mu \mathrm{g} / \mathrm{L}$, including beta-sitosterol, cholesterol, beta-stigmastanol, bis-2-ethylhexylphthalate, 2-beta coprostanol, and 4-nonylphenol diethoxylate (appendix table 1-2). Seventeen compounds, including several pesticides, fragrances, solvents, nonionic detergent metabolites, and compounds from other general use categories were analyzed for but not detected in any of the discrete water samples collected. Ten compounds were detected in at least one sample from all nine sites (appendix table 1-2). The average number of OWCs detected per discrete water sample from each site is presented in figure 8, grouped by general-use categories. Samples from U1 had the largest number of OWCs detected, and samples from R2 had the fewest. Detections in the wetland cells decreased in downstream order, indicating that the restored wetlands are providing some degree of favorable runoff treatment. The average number of OWCs was lowest at W3 - the outlet of the most downstream wetland cell. The "treatment" of OWCs in runoff by the wetlands is indicated by the adsorption of many OWCs onto sediments, the slowing of water flow from upstream OWC sources by the wetland cells, and thus, the settling of sediments in the restored wetlands, where compounds can undergo biodegradation.

Nine PAH compounds were targeted in the analysis of discrete water samples (table 4). All nine were detected in two samples collected from the upstream site U1, in one sample from residential site (R1) and in one sample from the most upstream wetland cell site (W1) (appendix table 1-2). The PAH compounds detected most often in discrete water samples were fluoranthene, pyrene, benzo[a]pyrene and phenanthrene. For total PAHs (sum of PAH concentrations in a sample), the continuous criterion concentration (CCC) for protection of human health, as defined in Indiana surface water-quality criteria for specific substances is $0.31 \mu \mathrm{g} / \mathrm{L}$ (Indiana Administrative Code, 2012). The CCC for total PAHs was exceeded by 9 of 67 discrete water samples (13 percent) collected in this study. Total PAHs in three of eight samples collected at site $\mathrm{W} 1$ and two of eight samples collected at sites U1, R1, and R3 exceeded the CCC. Indiana has not established water quality criteria for the other OWCs analyzed in this study.

Spatial patterns of seven frequently detected OWCs indicated the potential for environmental processes to decrease concentrations during transport through wetland cells. These OWCs included a fragrance (3-methyl-1H-indole), PAH compounds (anthracene, benzo[a]pyrene, fluoranthene, and pyrene), a pesticide and wood preservative (pentachlorophenol), and a fecal sterol (3-beta-coprostanol). For this discussion, "frequent detection" means that an OWC was detected in 33 percent or more of water samples from one or more of the three sampled site types (upstream, residential, restored wetland). These seven compounds were detected in samples from upstream or residential sites more frequently than at discharges from restored wetland cells (table 5). Six of the seven OWCs (excluding 3-methyl-1H-indole) are relatively hydrophobic and may be more affected by sorption onto and settling of suspended particulates. The log octanol-water partition coefficients $\left(\log \mathrm{K}_{\mathrm{OW}}\right)$ for these six OWCs range from 4.35 for anthracene to 8.82 for 3-beta-coprostanol (table 5). The $\mathrm{K}_{\mathrm{OW}}$ of a chemical compound represents the ratio of its solubility in octanol (a nonpolar solvent) to its solubility in water (a polar solvent). Log $\mathrm{K}_{\mathrm{OW}}$ values are generally inversely related to solubility in water and may be used as a relative indicator of the tendency of an organic compound to adsorb to soil or sediment (U.S. Environmental Protection Agency, 2004). The five OWCs detected more frequently in water from upstream sites than at wetland sites were 3-methyl-1H-indole, benzo[a] pyrene, fluoranthene, pyrene, and 3-beta-coprostanol. OWCs detected more frequently in water from residential sites than at wetland sites were anthracene, benzo[a]pyrene, fluoranthene, pyrene, and pentachlorophenol. 
Table 5. Most frequently detected organic wastewater compounds in water samples collected in and near Great Marsh at Beverly Shores, northwestern Indiana, 2009-11.

[Sampling site locations are shown in figure 3. Log Kow, base 10 logarithm of octanol-water partition coefficient; DEET, N,N-dimethyl-meta-toluamide; PAH, polycyclic aromatic hydrocarbon]

\begin{tabular}{|c|c|c|c|c|c|c|}
\hline \multirow[b]{2}{*}{ Compound name } & \multirow[b]{2}{*}{$\begin{array}{l}\text { General use } \\
\text { category }\end{array}$} & \multicolumn{5}{|c|}{ Percent detection } \\
\hline & & $\begin{array}{l}\text { Samples from } \\
\text { all sites }\end{array}$ & $\begin{array}{l}\text { Samples from } \\
\text { upstream sites }\end{array}$ & $\begin{array}{l}\text { Samples from } \\
\text { residential sites }\end{array}$ & $\begin{array}{l}\text { Samples from } \\
\text { restored wetland } \\
\text { sites }\end{array}$ & $\log K_{o w}$ \\
\hline Cholesterol & Sterol & 94.0 & 100 & 85.7 & 100 & 8.74 \\
\hline Beta-sitosterol & Sterol & 83.6 & 100 & 67.9 & 91.7 & 9.65 \\
\hline Indole & Fragrance & 71.6 & 80.0 & 60.7 & 79.2 & 2.05 \\
\hline p-cresol & Other & 65.7 & 73.3 & 64.3 & 62.5 & 2.06 \\
\hline Camphor & Flavoring & 62.7 & 80.0 & 57.1 & 58.3 & 3.04 \\
\hline Beta-stigmastanol & Sterol & 58.2 & 86.7 & 42.9 & 58.3 & 9.73 \\
\hline Isophorone & Solvent & 50.7 & 46.7 & 42.9 & 62.5 & 2.62 \\
\hline 3-methyl-1H-indole & Fragrance & 46.3 & 73.3 & 39.3 & 37.5 & 2.6 \\
\hline $\begin{array}{l}\text { N,N-diethyl- } \\
\text { meta-toluamide } \\
\text { (DEET) }\end{array}$ & Pesticide & 44.8 & 46.7 & 50.0 & 37.5 & 2.26 \\
\hline Pyrene & PAH & 46.3 & 66.7 & 53.6 & 25.0 & 4.93 \\
\hline Fluoranthene & PAH & 41.8 & 66.7 & 42.9 & 25.0 & 4.93 \\
\hline Phenanthrene & PAH & 32.8 & 40.0 & 35.7 & 25.0 & 4.35 \\
\hline 3-beta-coprostanol & Sterol & 33.3 & 60.0 & 22.2 & 29.2 & 8.82 \\
\hline Benzo[a]pyrene & PAH & 31.3 & 40.0 & 39.3 & 16.7 & 6.11 \\
\hline $\begin{array}{r}\text { 4-nonylphenol } \\
\text { diethoxylate }\end{array}$ & $\begin{array}{l}\text { Non-ionic } \\
\text { detergent }\end{array}$ & 28.4 & 26.7 & 21.4 & 37.5 & 5.3 \\
\hline Anthracene & PAH & 29.9 & 20.0 & 42.9 & 20.8 & 4.35 \\
\hline Pentachlorophenol & Pesticide & 25.4 & 6.7 & 42.9 & 16.7 & 4.74 \\
\hline $\begin{array}{l}\text { Number of samples } \\
\text { per site type }\end{array}$ & & 67 & 15 & 28 & 24 & \\
\hline
\end{tabular}

Several OWCs were frequently detected in water from nearly all sites (table 5). OWCs detected in samples from nearly all sites include the flavoring and odorant camphor; a fragrance (indole); a non-ionic detergent (4-nonylphenol diethoxylate); a wood preservative (p-cresol); a PAH (phenanthrene); a pesticide (DEET); a common solvent in paints, adhesives, wood preservative and pesticides (isophorone); and plant sterols (beta-sitosterol and beta-stigmastanol) (table 5). These detections indicate the potential for relatively widespread sources of the compounds across upstream, residential, and restored wetland sampling sites.

Pentachlorophenol was detected in seven of eight water samples collected from residential site R2 (appendix table 1-2). Trace concentrations of the OWC pentachlorophenol in water from site R2 may arise from weathering of the compound from older treated wood near the ditch upstream from R2. Pentachlorophenol was used as a treatment for utility poles, older treated wood, and in pesticide formulations. Pentachlorophenol detections at R2 were 7 of the 12 detections of the compound in samples from residential sites. About 43 percent of samples from residential sites had a detection of pentachlorophenol, and only about 31 percent of samples at the three other sites had detections. Site R2 water samples were from a ditch in the residential area that has several utility poles within $25 \mathrm{ft}$ of the ditch upstream from the site; however, it is not known whether the poles or other nearby wood are treated with pentachlorophenol. 


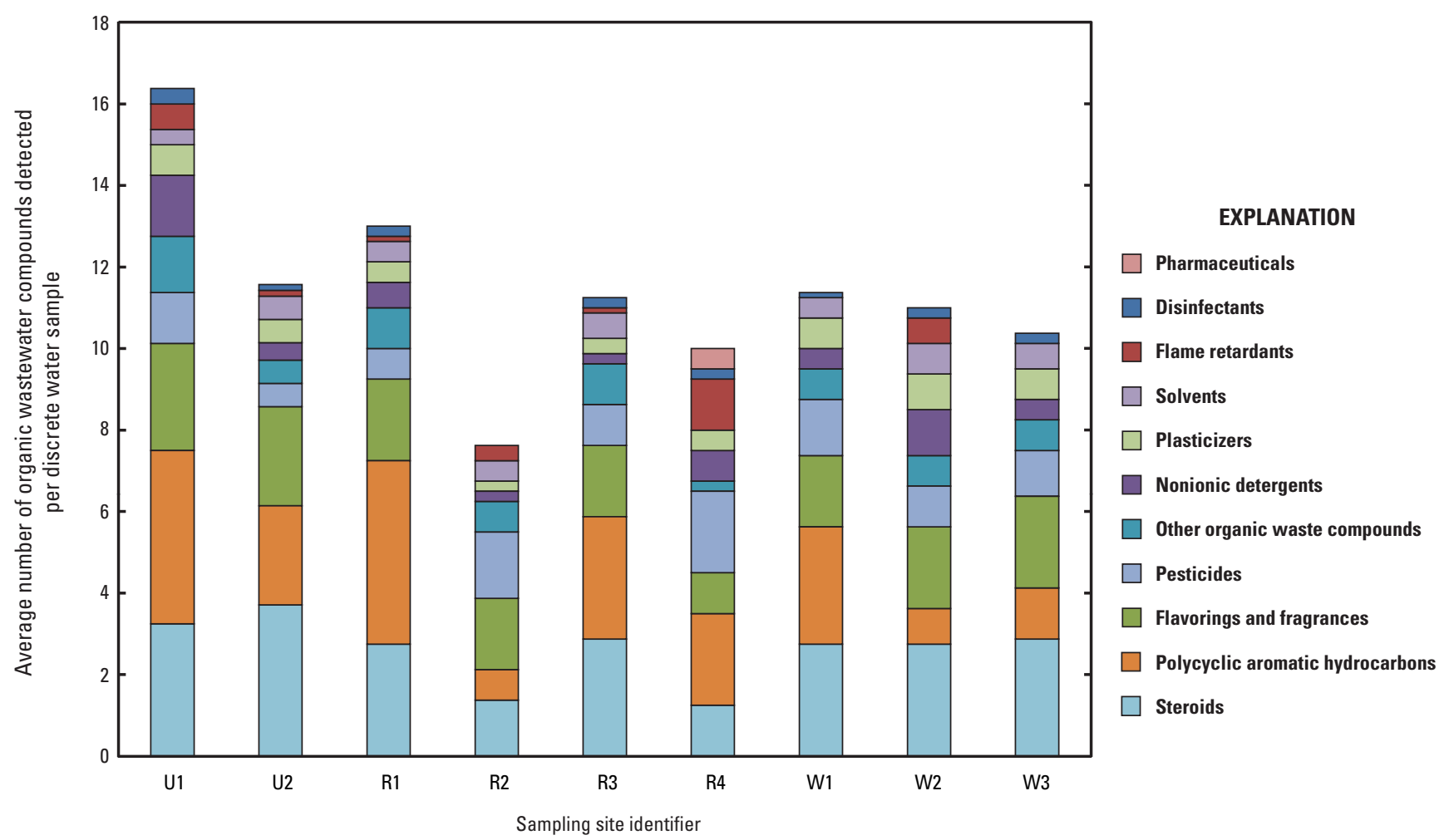

Figure 8. Average number of organic wastewater compounds detected per discrete water sample.

\section{Organic Wastewater Compounds in Time- Averaged Water Samples}

In total, 44 out of 69 targeted OWCs were detected in the time-averaged POCIS samples collected at upstream site $\mathrm{U} 1$, residential sites R1 and R2, and restored wetland site W3 during the April 2011 and November-December 2011 deployments (table 6). Nine compounds, including a solvent (isopropyl benzene), a disinfectant (phenol), a fragrance (acetophenone), a wood preservative and disinfectant (p-cresol), a PAH (naphthalene), an insect repellant (DEET), plasticizers (ditethyl phthalate and diethylhexyl phthalate), and a sterol (cholesterol) were detected in all eight POCIS samples. Nearly twice as many OWCs were detected in at least one POCIS sample from the first deployment than the second. Forty-one compounds were detected in at least 1 sample from the spring (April 2011) deployment; 24 compounds were detected in at least 1 sample from the fall (November-December 2011) deployment (table 6). Samples from the spring deployment averaged 32 OWC detections per sample; samples from the fall deployment averaged 16 OWC detections per sample. This difference may be a result of higher streamflow during the spring deployment.

Estimated concentrations of OWCs from the POCIS samples were compared to reported concentrations from discrete water samples. Extended deployment of the POCIS allowed reporting of some OWCs at lower concentrations than were possible with discrete water samples. As a result, 3 compounds, including a solvent (isopropyl benzene), a pharmaceutical (caffeine), and a fragrance (hexahydrohexamethyl cyclopentabenzopyran, HHCB) were detected in half or more of the POCIS samples, but not in any of the 67 discrete water samples. Isopropyl benzene was not detected in any of 67 discrete water samples at a reporting limit of less than $200 \mathrm{ng} / \mathrm{L}$, but it was detected in all 8 POCIS samples, at an average concentration of $28 \mathrm{ng} / \mathrm{L}$. Caffeine was not detected in all 67 discrete water samples at a reporting limit of less than $200 \mathrm{ng} / \mathrm{L}$ or in POCIS extracts from the November-December 2011 deployment, but it was detected in all 4 POCIS extracts from the April 2011 deployment, at an average concentration of $6 \mathrm{ng} / \mathrm{L}$. HHCB was not detected in all 67 discrete water samples, but it was detected in 5 of 8 POCIS samples, at an average concentration of $0.9 \mathrm{ng} / \mathrm{L}$.

The YES assay detected estrogenicity in the POCIS extracts from the restored wetland cell at W3 in both the April and November-December 2011 deployments and at residential site R2 and upstream site U1 in the November-December 2011 deployment only (table 7). Estrogenicity describes the characteristics of a water sample that together have the physiological effect of natural estrogens. The measured estrogenicity in the R2 and U1 samples was very near the detection limit, which may explain the lack of detection during the April deployment. No estrogenic response was observed from any blank samples, indicating that the sampler matrix and sample processing steps did not contribute to the total measured estrogenicity. 
Table 6. Organic wastewater compounds detected in samples collected by polar organic chemical integrative samplers in and near Great Marsh at Beverly Shores, northwestern Indiana, April and November-December 2011.

[Sampling site locations are shown in figure 3. ng/L, nanograms of chemical per liter of water; (m), highly variable compound; E, result qualified as estimated due to continuing calibration verification (CCV) criteria failure, D1/D2, deployment number for which the E qualifer applies; n.d., not detected; DEET, N,N-diethyl-meta-toluamide. General use category: DISINF, disinfectant group, FIRE, flame retardant; FLAV, flavoring; FRAG, fragrance; NID, nonionic detergent; PAH, polycyclic aromatic hydrocarbon, PEST, pesticide group; PHARM, pharmaceutical; SOLV, solvent]

\begin{tabular}{|c|c|c|c|c|c|c|c|c|c|c|}
\hline \multirow{4}{*}{ Compound name } & \multirow{4}{*}{$\begin{array}{c}\text { Data } \\
\text { qualifiers }\end{array}$} & \multirow{4}{*}{$\begin{array}{l}\text { General } \\
\text { use } \\
\text { category }\end{array}$} & \multirow{2}{*}{\multicolumn{4}{|c|}{ Deployment 1 (April 1-29, 2011) }} & \multirow{2}{*}{\multicolumn{4}{|c|}{$\begin{array}{c}\text { Deployment } 2 \text { (November 2, 2011- } \\
\text { December 2, 2011) } \\
\text { Sampling site name } \\
\end{array}$}} \\
\hline & & & & & & & & & & \\
\hline & & & U1 & R1 & R2 & W3 & U1 & R1 & $\mathbf{R 2}$ & W3 \\
\hline & & & $\begin{array}{c}\text { Estimated } \\
\text { concentra- } \\
\text { tion } \\
\text { (ng/L) }\end{array}$ & $\begin{array}{l}\text { Estimated } \\
\text { concentra- } \\
\text { tion } \\
\text { (ng/L) }\end{array}$ & $\begin{array}{l}\text { Estimated } \\
\text { concentra- } \\
\text { tion } \\
\text { (ng/L) }\end{array}$ & $\begin{array}{l}\text { Estimated } \\
\text { concentra- } \\
\text { tion } \\
\text { (ng/L) }\end{array}$ & $\begin{array}{l}\text { Estimated } \\
\text { concentra- } \\
\text { tion } \\
\text { (ng/L) }\end{array}$ & $\begin{array}{l}\text { Estimated } \\
\text { concentra- } \\
\text { tion } \\
\text { (ng/L) }\end{array}$ & $\begin{array}{l}\text { Estimated } \\
\text { concentra- } \\
\text { tion } \\
\text { (ng/L) }\end{array}$ & $\begin{array}{c}\text { Estimated } \\
\text { concentration } \\
\text { (ng/L) }\end{array}$ \\
\hline 1,4-dichlorobenzene & None & PEST & 6.8 & 7.3 & 6.4 & 12 & n.d. & 46 & n.d. & 89 \\
\hline 1-methylnaphthalene & None & PAH & 1.5 & 4.5 & 2.2 & 1.3 & n.d. & n.d. & n.d. & n.d. \\
\hline 2-methylnaphthalene & None & PAH & 3.7 & 3.0 & 4.8 & 3.4 & 2.4 & n.d. & 2.5 & n.d. \\
\hline $\begin{array}{l}\text { 3,4-dichlorophenyl } \\
\text { isocyanate }\end{array}$ & $(\mathrm{m})$ & PEST & 1.7 & n.d. & n.d. & n.d. & n.d. & n.d. & n.d. & n.d. \\
\hline 3-beta-coprostanol & $\begin{array}{l}(\mathrm{m}), \mathrm{E} \\
\text { (D1) }\end{array}$ & STEROL & n.d. & 130 & n.d. & n.d. & 280 & n.d. & n.d. & n.d. \\
\hline 3-methyl-1H-indole & None & FRAG & 3.4 & 5.0 & 3.2 & 3.5 & n.d. & n.d. & n.d. & n.d. \\
\hline $\begin{array}{l}\text { 4-nonylphenol (sum } \\
\text { of all isomers) }\end{array}$ & $(\mathrm{m})$ & NID & n.d. & 18 & n.d. & 42 & n.d. & n.d. & n.d. & n.d. \\
\hline $\begin{array}{l}\text { 4-nonylphenol } \\
\text { diethoxylate (sum } \\
\text { of all isomers) }\end{array}$ & $\begin{array}{r}(\mathrm{m}), \mathrm{E} \\
(\mathrm{D} 1)\end{array}$ & NID & n.d. & 110 & n.d. & n.d. & 301 & n.d. & n.d. & n.d. \\
\hline $\begin{array}{l}\text { 4-tert- } \\
\text { octylphenol } \\
\text { diethoxylate }\end{array}$ & $(\mathrm{m})$ & NID & n.d. & n.d. & n.d. & n.d. & 26 & n.d. & n.d. & n.d. \\
\hline 9,10 -anthraquinone & $(\mathrm{m})$ & PEST & n.d. & 16 & n.d. & n.d. & n.d. & n.d. & n.d. & n.d. \\
\hline Acetophenone & None & FRAG & 12 & 37 & 35 & 32 & 20 & 31 & 35 & 23 \\
\hline Anthracene & None & PAH & n.d. & 11 & 1.3 & n.d. & n.d. & n.d. & n.d. & n.d. \\
\hline Atrazine & None & PEST & n.d. & 23 & n.d. & 44 & n.d. & n.d. & n.d. & n.d. \\
\hline Benzo[a]pyrene & None & PAH & n.d. & 11 & n.d. & n.d. & n.d. & n.d. & n.d. & n.d. \\
\hline Benzophenone & None & OTHER & 2.4 & 3.8 & 2.7 & 6.7 & n.d. & n.d. & n.d. & n.d. \\
\hline beta-Sitosterol & $\begin{array}{l}(\mathrm{m}), \mathrm{E} \\
(\mathrm{D} 1 / \\
\mathrm{D} 2)\end{array}$ & STEROL & n.d. & 340 & n.d. & 310 & 1,200 & 720 & 700 & 650 \\
\hline Beta-stigmastanol & $\begin{array}{r}(\mathrm{m}), \mathrm{E} \\
\text { (D1) }\end{array}$ & STEROL & n.d. & 167 & n.d. & n.d. & 390 & n.d. & n.d. & n.d. \\
\hline $\begin{array}{l}\text { Bis(2-ethylhexyl) } \\
\text { phthalate }\end{array}$ & $\mathrm{E}(\mathrm{D} 1)$ & PLAS & 540 & 330 & 220 & 340 & 200 & 180 & 410 & 120 \\
\hline Bisphenol A & $\begin{array}{r}(\mathrm{m}), \mathrm{E} \\
(\mathrm{D} 1)\end{array}$ & PLAS & 1.4 & 2.6 & 0.7 & 1.5 & n.d. & n.d. & n.d. & n.d. \\
\hline Bromacil & None & PEST & n.d. & n.d. & n.d. & n.d. & 58 & n.d. & n.d. & n.d. \\
\hline Caffeine & None & PHARM & 5.5 & 7.4 & 3.3 & 8.0 & n.d. & n.d. & n.d. & n.d. \\
\hline Camphor & None & FLAV & 12 & 8.7 & 8.5 & 10 & 8.4 & 15 & n.d. & 36 \\
\hline
\end{tabular}


Table 6. Organic wastewater compounds detected in samples collected by polar organic chemical integrative samplers in and near Great Marsh at Beverly Shores, northwestern Indiana, April and November-December 2011._Continued

[Sampling site locations are shown in figure 3. ng/L, nanograms of chemical per liter of water; (m), highly variable compound; E, result qualified as estimated due to continuing calibration verification (CCV) criteria failure, D1/D2, deployment number for which the E qualifer applies; n.d., not detected; DEET, N,N-diethyl-meta-toluamide. General use category: DISINF, disinfectant group, FIRE, flame retardant; FLAV, flavoring; FRAG, fragrance; NID, nonionic detergent; PAH, polycyclic aromatic hydrocarbon, PEST, pesticide group; PHARM, pharmaceutical; SOLV, solvent]

\begin{tabular}{|c|c|c|c|c|c|c|c|c|c|c|}
\hline \multirow{4}{*}{ Compound name } & \multirow{4}{*}{$\begin{array}{c}\text { Data } \\
\text { qualifiers }\end{array}$} & \multirow{4}{*}{$\begin{array}{l}\text { General } \\
\text { use } \\
\text { category }\end{array}$} & \multirow{2}{*}{\multicolumn{4}{|c|}{ Deployment 1 (April 1-29, 2011) }} & \multirow{2}{*}{\multicolumn{4}{|c|}{$\begin{array}{c}\text { Deployment } 2 \text { (November 2, 2011- } \\
\text { December 2, 2011) } \\
\text { Sampling site name }\end{array}$}} \\
\hline & & & & & & & & & & \\
\hline & & & U1 & R1 & $\mathbf{R 2}$ & W3 & U1 & R1 & R2 & W3 \\
\hline & & & $\begin{array}{l}\text { Estimated } \\
\text { concentra- } \\
\text { tion } \\
\text { (ng/L) }\end{array}$ & $\begin{array}{l}\text { Estimated } \\
\text { concentra- } \\
\text { tion } \\
\text { (ng/L) }\end{array}$ & $\begin{array}{l}\text { Estimated } \\
\text { concentra- } \\
\text { tion } \\
\text { (ng/L) }\end{array}$ & $\begin{array}{l}\text { Estimated } \\
\text { concentra- } \\
\text { tion } \\
\text { (ng/L) }\end{array}$ & $\begin{array}{c}\text { Estimated } \\
\text { concentra- } \\
\text { tion } \\
\text { (ng/L) }\end{array}$ & $\begin{array}{l}\text { Estimated } \\
\text { concentra- } \\
\text { tion } \\
\text { (ng/L) }\end{array}$ & $\begin{array}{l}\text { Estimated } \\
\text { concentra- } \\
\text { tion } \\
\text { (ng/L) }\end{array}$ & $\begin{array}{c}\text { Estimated } \\
\text { concentration } \\
\text { (ng/L) }\end{array}$ \\
\hline Cholesterol & $\begin{array}{l}(\mathrm{m}), \mathrm{E} \\
(\mathrm{D} 1)\end{array}$ & STEROL & 270 & 300 & 260 & 760 & 310 & 130 & 120 & 130 \\
\hline DEET & $\mathrm{E}(\mathrm{D} 1)$ & PEST & 3.7 & 3.8 & 22 & 6.2 & 2.0 & 2.0 & 13 & 6.7 \\
\hline Diethyl phthalate & None & PLAS & 42 & 35 & 260 & 24 & 29 & 23 & 29 & 19 \\
\hline D-limonene & None & FRAG & 3.5 & 15 & 9.6 & 34 & 25 & 20 & 15 & n.d. \\
\hline Fluoranthene & None & PAH & 0.6 & 5.5 & 0.4 & n.d. & n.d. & n.d. & n.d. & n.d. \\
\hline $\begin{array}{l}\text { Hexahydrohexamethyl } \\
\text { cyclopentabenzo- } \\
\text { pyran }\end{array}$ & None & FRAG & 0.3 & 0.8 & 1.1 & 0.3 & n.d. & n.d. & 2.1 & n.d. \\
\hline Indole & None & FRAG & 11 & 35 & 45 & 19 & n.d. & n.d. & 12 & 8.4 \\
\hline Isophorone & None & SOLV & 0.8 & 1.9 & 2.2 & 2.8 & n.d. & n.d. & n.d. & 4.1 \\
\hline Isopropylbenzene & None & SOLV & 31 & 34 & 57 & 24 & 22 & 36 & 6.6 & 11 \\
\hline Menthol & None & FLAV & 35 & 50 & 45 & 64 & n.d. & n.d. & n.d. & n.d. \\
\hline Methyl salicylate & None & OTHER & 11 & 23 & 15 & 25 & n.d. & n.d. & n.d. & n.d. \\
\hline Metolachlor & None & PEST & n.d. & n.d. & n.d. & 0.9 & n.d. & n.d. & n.d. & n.d. \\
\hline Naphthalene & None & PAH & 3.4 & 70 & 5.8 & 4.3 & 3.2 & 3.2 & 1.9 & 3.1 \\
\hline p-cresol & None & OTHER & 61 & 240 & 85 & 22 & 10 & 140 & 170 & 23 \\
\hline Pentachlorophenol & $\begin{array}{l}\text { (m), E } \\
\text { (D1) }\end{array}$ & PEST & n.d. & 40 & 160 & 32 & 25 & n.d. & 27 & n.d. \\
\hline Phenanthrene & None & PAH & 0.3 & 0.8 & n.d. & n.d. & n.d. & n.d. & n.d. & n.d. \\
\hline Phenol & None & DISINF & 7.3 & 39 & 9.5 & 8.5 & 6.5 & 38 & 39 & 10 \\
\hline Prometon & None & PEST & 1.1 & n.d. & n.d. & n.d. & n.d. & n.d. & n.d. & n.d. \\
\hline Pyrene & None & PAH & 1.1 & 6.0 & n.d. & n.d. & n.d. & n.d. & n.d. & n.d. \\
\hline Triclosan & None & DISINF & n.d. & n.d. & n.d. & n.d. & 0.6 & n.d. & n.d. & n.d. \\
\hline Triphenyl phosphate & None & FIRE & 15 & 13 & 12 & 12 & n.d. & n.d. & n.d. & n.d. \\
\hline $\begin{array}{l}\text { Tris(2-chloroethyl) } \\
\text { phosphate }\end{array}$ & None & FIRE & 1.5 & 1.4 & 3.2 & 1.6 & n.d. & n.d. & n.d. & n.d. \\
\hline $\begin{array}{l}\text { Number of com- } \\
\text { pounds detected per } \\
\text { sample }\end{array}$ & & & 30 & 38 & 28 & 30 & 20 & 13 & 15 & 14 \\
\hline
\end{tabular}


Table 7. Estrogenic potential of chemicals, expressed as estimated average water concentrations relative to estimated estradiol equivalents, in water samples collected by polar organic chemical integrative samplers in and near Great Marsh at Beverly Shores, northwestern Indiana, April and November-December 2011.

[Sampling site locations are shown in figure 3. EEQ, estradiol equivalent; ng/L, nanograms of chemical per liter of water; n.d., not detected; n.c., not collected]

\begin{tabular}{|c|c|c|c|c|c|c|}
\hline \multirow[b]{2}{*}{ Deployment period } & \multicolumn{6}{|c|}{ Sampling site name } \\
\hline & $\begin{array}{c}\text { U1 } \\
\text { EEO in ng/L }\end{array}$ & $\begin{array}{l}\text { U1-Replicate } \\
\text { EEO in ng/L }\end{array}$ & $\begin{array}{c}\text { R1 } \\
\text { EE0 in ng/L }\end{array}$ & $\begin{array}{c}\text { R2 } \\
\text { EEO in ng/L }\end{array}$ & $\begin{array}{c}\text { W3 } \\
\text { EE0 in ng/L }\end{array}$ & $\begin{array}{l}\text { W3-Replicate } \\
\text { EE0 in ng/L }\end{array}$ \\
\hline $\begin{array}{l}\text { April 1, } 2011 \text { to April 29, } 2011 \\
\text { (28 days) }\end{array}$ & n.d. & n.c. & n.d. & n.d. & 2.7 & 1.4 \\
\hline $\begin{array}{l}\text { November 2, } 2011 \text { to December 2, } 2011 \\
\text { (30 days) }\end{array}$ & 0.2 & n.d. & n.d. & 0.12 & 3.5 & n.c. \\
\hline
\end{tabular}

${ }^{1}$ No estrogenicity was measured greater than the background 99-percent confidence interval determined from reagent blanks run concurrently with each sample.

\section{Indicators of Residential Onsite Wastewater Disposal Effluent}

Previous investigations have analyzed OWCs in samples of septic tank effluent and water from human-affected streams. Hinkle and others (2005) detected 3-beta-coprostanol, caffeine, cholesterol, N, N-diethyl-meta-toluamide (DEET), diethoxynonylphenol (referred to as 4-nonylphenol diethoxylate), p-cresol, tris (2-chloroethyl) phosphate, and triphenyl phosphate in more than 90 percent of septic system effluent samples. These same compounds were frequently detected in human-affected streams by Kolpin and others (2002), and are proposed by Hinkle and others (2005) to be reliable indicators of wastewater in aqueous environments. Hereafter in this report, these eight OWCs are referred to as septic tank indicator compounds.

Seven of eight septic tank indicator compounds were detected in discrete water samples collected in the study area (table 8, appendix table 1-2). All eight were detected in at least one POCIS sample (table 8). Median concentrations of septic tank indicator compounds in discrete water samples and estimated concentrations in POCIS samples were generally small but the detection of the compounds was widespread across the sampled sites. Comparison to previously published data (Kolpin and others, 2002) shows that most concentrations of septic tank indicator compounds in the study area are lower than those found in a nationwide reconnaissance of 139 U.S. streams that are affected by human, industrial, and agricultural wastewaters. Two compounds (p-cresol and cholesterol) were detected at concentrations greater than the median and maximum concentrations in U.S. streams affected by human, industrial, and agricultural wastewaters (Kolpin and others, 2002). As expected, the concentrations of septic tank indicator compounds in the study area are considerably lower than concentrations detected in samples of onsite wastewater (septic tank) effluent described by Hinkle and others (2005).

Detection frequencies of the fecal sterol, cholesterol; the fecal sterol metabolite, 3-beta-coprostanol; and the plant sterol metabolite, beta-sitosterol, indicate the likelihood of natural or uncharacterized upstream sources of these compounds. The sterols 3-beta-coprostanol, beta-sitosterol, and beta-stigmastanol were each detected in higher percentages in water samples from upstream sites than in water samples from the residential sites (table 4). Research by Saim and others (2009) indicated that 3-beta-coprostanol, cholesterol, and beta-sitosterol can be useful source tracers of fecal contamination in water. Leeming and others (1998) indicated that the ratio of 3-beta-coprostanol to cholesterol could be used to differentiate sources of fecal pollution. For water samples reflecting avian contamination (chicken and quail farms) the ratio of 3-beta-coprostanol to cholesterol was about 0.1 to 0.2 and was lower than the ratios from horse farms (0.6) and from wastewater treatment plant effluent (principally human source, 0.5 ) (Leeming and others, 1998). Ratios computed from 18 samples of residential septic tank effluent (Hinkle and others, 2006) ranged from 0.30 to 1.15 , with a median value of 0.50 .

Ratios of 3-beta-coprostanol to cholesterol in 19 environmental samples from the study area in which both compounds were detected ranged from 0.06 to 0.56 with a median of 0.25 . The frequent detection of fecal sterols and metabolites and the 3-beta coprostanol to cholesterol ratios are consistent with mixed mammalian and avian sources, both of which are likely to have natural origins at the upstream and wetland sites.

DEET, a widely used ingredient in insect repellants that can be applied in aerosol or topical form, was detected in similar percentages of water samples from all sites. Detection frequencies ranged from 37.5 percent of samples at restored wetland sites to 50.0 percent of samples at residential sites (table 5). Sewage effluent is the primary pathway for DEET to enter aquatic environments following washing off and absorption/excretion by humans (Costanzo and others, 2007). DEET was detected in concentrations above the reporting limit most frequently in samples from the residential sites R2 (six of eight samples) and R4 (four of four samples).

Concentrations of DEET in samples from sites R2 and R4 indicate the likely presence of DEET in groundwater beneath different parts of the residential area (appendix table 1-2). All four samples from a tile drain access that collects groundwater 
Table 8. Summary of septic tank indicator compounds detected in water samples collected in and near Great Marsh at Beverly Shores, northwestern Indiana, 2009-11 and concentrations of those compounds detected by other studies.

[Sampling site locations are shown in figure 3. $\mu \mathrm{g} / \mathrm{L}$, micrograms per liter; DEET, N,N-diethyl-meta-toluamide; n.d., not detected. Shaded cell indicates median or maximum compound concentration greater than comparable median or maximum concentration in population of samples reported by Kolpin and others, 2002]

\begin{tabular}{|c|c|c|c|c|c|c|c|c|c|}
\hline $\begin{array}{l}\text { Description of statistic } \\
\text { or concentration }\end{array}$ & $\begin{array}{c}\text { Sampling site name } \\
\text { and deployment } \\
\text { number }\end{array}$ & $\begin{array}{c}\text { Tris(2- } \\
\text { chloroethyl) } \\
\text { phosphate } \\
(\mu \mathrm{g} / \mathrm{L})\end{array}$ & $\begin{array}{c}\text { Triphenyl } \\
\text { phosphate } \\
\text { ( } \mu \mathrm{g} / \mathrm{L})\end{array}$ & $\begin{array}{c}\text { p-cresol } \\
(\mu \mathrm{g} / \mathrm{L})\end{array}$ & $\begin{array}{l}\text { DEET } \\
(\mu \mathrm{g} / \mathrm{L})\end{array}$ & $\begin{array}{l}\text { 3-beta-co- } \\
\text { prostanol } \\
(\mu \mathrm{g} / \mathrm{L})\end{array}$ & $\begin{array}{l}\text { Cholesterol } \\
(\mu \mathrm{g} / \mathrm{L})\end{array}$ & $\begin{array}{c}\text { 4-nonylphe- } \\
\text { nol diethoxyl- } \\
\text { ate } \\
(\mu \mathrm{g} / \mathrm{L})\end{array}$ & $\begin{array}{c}\text { Caffeine } \\
\text { ( } \mu \mathrm{g} / \mathrm{L})\end{array}$ \\
\hline $\begin{array}{l}\text { Median concentrations } \\
\text { detected in discrete } \\
\text { water samples from } \\
\text { in and near the Great } \\
\text { Marsh at Beverly } \\
\text { Shores, Ind. }\end{array}$ & & $<0.16$ & $<0.08$ & 0.028 & $<0.04$ & $<1.6$ & 0.81 & $<1.6$ & $<0.2$ \\
\hline $\begin{array}{l}\text { Maximum concentra- } \\
\text { tions detected in dis- } \\
\text { crete water samples } \\
\text { from in and near the } \\
\text { Great Marsh at Bev- } \\
\text { erly Shores, Ind. }\end{array}$ & & E 0.067 & 0.01 & 1.50 & 0.49 & E2.48 & E11 & E2.38 & $<0.2$ \\
\hline \multirow{8}{*}{$\begin{array}{l}\text { Estimated concentra- } \\
\text { tion from POCIS } \\
\text { samples from in and } \\
\text { near the Great Marsh } \\
\text { at Beverly Shores, } \\
\text { Ind. }\end{array}$} & U1- Deployment 1 & 0.002 & 0.015 & 0.061 & 0.004 & n.d. & 0.270 & n.d. & 0.005 \\
\hline & U1- Deployment 2 & n.d. & n.d. & 0.010 & 0.002 & 0.280 & 0.310 & 0.301 & n.d. \\
\hline & R1- Deployment 1 & 0.001 & 0.013 & 0.240 & 0.004 & 0.130 & 0.300 & 0.110 & 0.007 \\
\hline & R1- Deployment 2 & n.d. & n.d. & 0.140 & 0.002 & n.d. & 0.130 & n.d. & n.d. \\
\hline & R2- Deployment 1 & 0.003 & 0.012 & 0.085 & 0.022 & n.d. & 0.260 & n.d. & 0.003 \\
\hline & R2- Deployment 2 & n.d. & n.d. & 0.170 & 0.013 & n.d. & 0.120 & n.d. & n.d. \\
\hline & W3- Deployment 1 & 0.002 & 0.012 & 0.022 & 0.006 & n.d. & 0.760 & n.d. & 0.008 \\
\hline & W3- Deployment 2 & n.d. & n.d. & 0.023 & 0.007 & n.d. & 0.130 & n.d. & n.d. \\
\hline $\begin{array}{l}\text { Median concentrations } \\
\text { detected from } 139 \\
\text { U.S. streams affected } \\
\text { by human, indus- } \\
\text { trial, and agricultural } \\
\text { wastewaters (Kolpin } \\
\text { and others, 2002) }\end{array}$ & & $<0.16$ & 0.04 & 0.05 & 0.06 & E0.7 & E1 & E1 & 0.1 \\
\hline $\begin{array}{l}\text { Maximum concentra- } \\
\text { tions detected from } \\
139 \text { U.S. streams } \\
\text { affected by human, } \\
\text { industrial, and agri- } \\
\text { cultural wastewaters } \\
\text { (Kolpin and others, } \\
\text { 2002) }\end{array}$ & & 0.54 & 0.22 & 0.540 & 1.1 & E9.8 & E10 & E9 & 5.7 \\
\hline $\begin{array}{l}\text { Median concentrations } \\
\text { detected in } 21 \text { onsite } \\
\text { wastewater samples, } \\
\text { La Pine, Orgeon, } \\
2003 \text { (Hinkle and } \\
\text { others, 2005) }\end{array}$ & & E0.4 & E0.4 & E310 & 0.8 & E11 & E28 & E15 & 12 \\
\hline $\begin{array}{l}\text { Maximum concentra- } \\
\text { tions detected in } 21 \\
\text { onsite wastewater } \\
\text { samples, La Pine, } \\
\text { Orgeon, 2003 } \\
\text { (Hinkle and others, } \\
\text { 2005) }\end{array}$ & & 1.9 & 0.9 & 1,300 & 52 & 53 & 320 & E130 & 320 \\
\hline
\end{tabular}


from the residential area (R4) contained the largest concentrations of DEET, which ranged from 0.17 to $0.49 \mu \mathrm{g} / \mathrm{L}$; these were the largest concentrations detected by this study. Estimated DEET concentrations detected in six of eight surfacewater samples from site R2 ranged from 0.08 to $0.17 \mu \mathrm{g} / \mathrm{L}$. These data indicate that groundwater in the surficial aquifer is a potential source of DEET to the restored wetlands.

With the exception of nitrate concentrations in water samples from sites R2 and R4, no persistent inorganic indicators of wastewater contamination in water samples were identified to compare with the OWC results. Nitrate concentrations in groundwater from the tile drain at site $\mathrm{R} 4$ were 2.15 and $2.83 \mathrm{mg} / \mathrm{L}$ as $\mathrm{N}$ in samples collected on June 18, 2010, and December 2, 2011, respectively (appendix table 1-3). In addition, the residential area sample from site R2 on December 2,2011 , also had a nitrate concentration of $0.42 \mathrm{mg} / \mathrm{L}$ as $\mathrm{N}$. These concentrations from the septic-sewered residential area were greater than the nitrate concentration range of four upstream samples (less than 0.04 to $0.38 \mathrm{mg} / \mathrm{L}$ as nitrogen) and four residential area samples from sites R1 and R3 (less than 0.04 to $0.13 \mathrm{mg} / \mathrm{L}$ as nitrogen). Nitrate concentrations in samples from wetland sites (less than 0.04 to $0.11 \mathrm{mg} / \mathrm{L}$ as nitrogen) were within the range of nitrate concentrations from the upstream sites.

\section{Transport and Fate of Organic Wastewater Compounds in Great Marsh}

Transport and fate of OWCs were evaluated through three methods: computation and comparison of OWC loads at wetland outlets, analysis of OWC concentrations in wetland sediment samples, and laboratory microcosm experiments using wetland sediment samples from the study area. Median total loads of OWCS were higher for samples collected in spring and summer than those collected in fall, corresponding with higher streamflow from the wetland cells during the spring and summer seasons.

\section{Hydrologic Influences on Organic Wastewater Compound Transport}

Surface-water levels in the wetland were monitored continuously at W1, W2, and W3 (fig. 9). Water-level fluctuations were largest at W3, the most downstream site (table 9). Discrete water samples were collected over a range of waterlevel conditions (fig. 10).

Seven-day precipitation totals show that periods of high precipitation were most common in May, June, and July during the study period (fig. 10). Surface-water levels were also most variable during May, June, and July (fig. 9). Surfacewater levels in the wetland cells were lower during fall months and generally increased following winter snowmelt and spring precipitation (fig. 9).

Annual total rainfall for 2010 and 2011 was 40.18 inches (in.) and 44.54 in., respectively. Annual precipitation during the study period (2010-11) was above the median annual precipitation of $36.65 \mathrm{in}$. reported from 1952 to 2009 (Buszka and others, 2011). The two largest single day total precipitation events during the study period were June 23, 2010 (2.4 in.), and July 1, 2011 (2.77 in.).

Storm-event response of the wetland cells was demonstrated during a temporally isolated, intense precipitationevent in early summer, 2011. Surface-water levels in the wetland cells responded quickly to precipitation and receded to near pre-precipitation levels within approximately 2 days (table 10). Hydrographs from sites W1, W2, and W3 during the largest single-day total precipitation event during the study period, on July 1, 2011, are presented in figure 11. Prior to this event, water levels in the wetland cells were nearly unchanging. The water level at W3 was $597.04 \mathrm{ft}$, compared to the median water level of $597.08 \mathrm{ft}$ measured over the study period (December 2009- December 2011). Less than 0.1 in. of rain had fallen from June 24 to June 30. Light rain showers began around 5 p.m. eastern standard time (EST) on June 30 , with the most intense rain (1.72 in./hour) falling around 9:00 a.m. EST on July 1, 2011. Rainfall totals for June 30 and July 1 were 0.57 in. and 2.77 in., respectively. No additional rain fell from July 2 to July 11 . The wetland cells responded quickly - water levels began rising at the most upstream wetland cell within 3 hours (table 10, fig. 11). The fastest increase in water level was demonstrated at $\mathrm{W} 3$, where the water level rose $0.18 \mathrm{ft}$ in 30 minutes in the hour following the most intense period of rainfall. The wetland cells responded in sequence to the event - the water levels peaked in downstream order, with W1 peaking first, followed by W2, and W3 followed 12 hours later (table 10). The water levels rose by $0.93 \mathrm{ft}$ at site $\mathrm{W} 1$, whereas the level at $\mathrm{W} 3$ rose by $1.53 \mathrm{ft}$. Water levels in the wetland cells receded in the days following the storm - at W3, water levels rose by $1.53 \mathrm{ft}$ and then fell by $0.94 \mathrm{ft}$ within 48 hours (table 10).

Spillway conditions and water-level controls changed frequently due to debris accumulation, beaver activity, and site maintenance activities, and as a result a stable relation ("rating") could not be defined between surface-water levels (stage) and streamflow at the wetland spillways. Thus, estimates of streamflow between measurements could not be made. When possible, streamflow measurements were made concurrently with sample collection (table 11). During extended dry periods (primarily late summer and early fall), the water levels in the wetland cells fell below the elevation of the control structures and ceased to flow over the spillways. Zero-flow conditions were noted at the time of sample collection. 


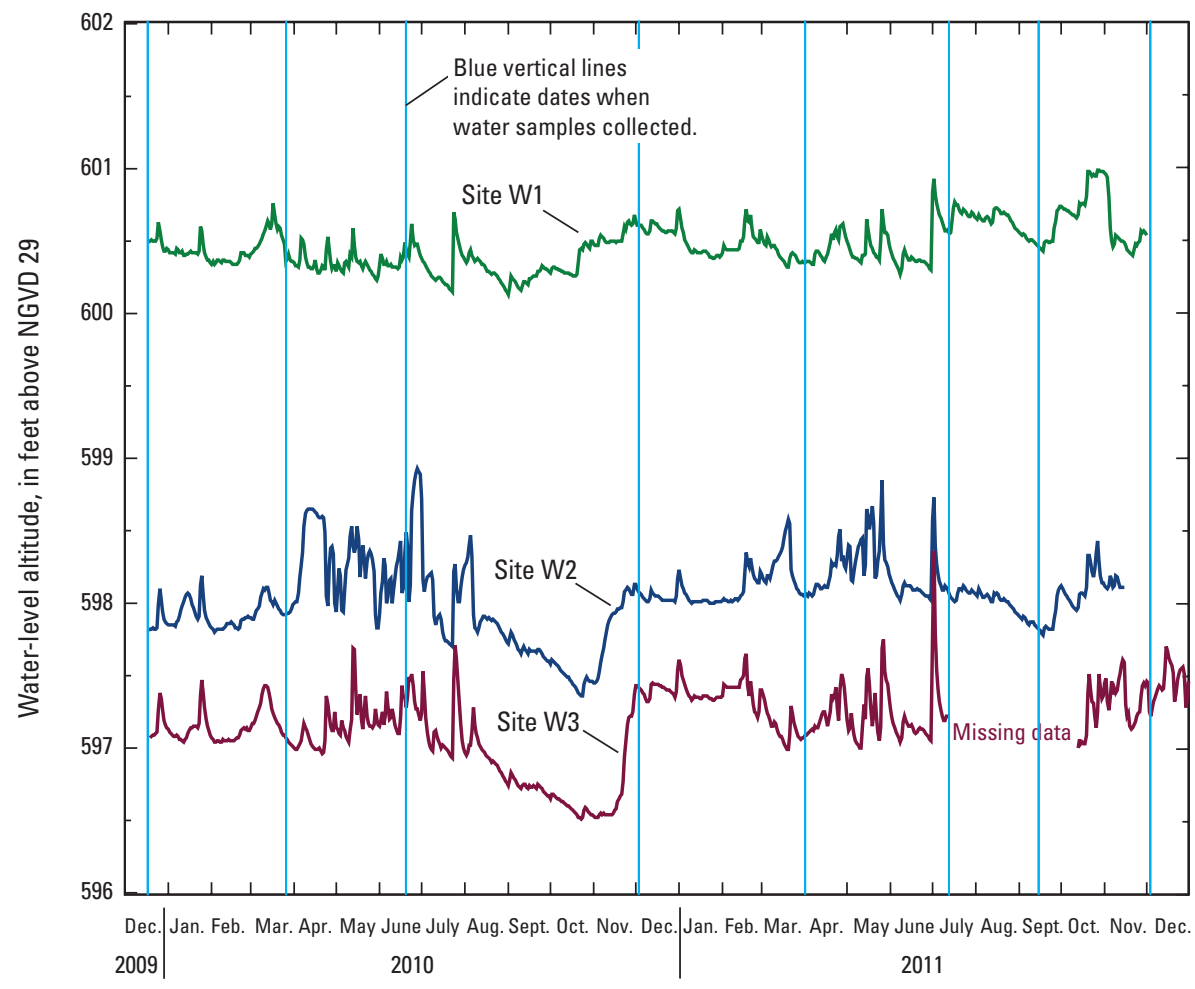

Figure 9. Continuous water levels from wetland cells at sites W1, W2, and W3.

Table 9. Summary of continuous water-level data in wetland cells in Great Marsh at Beverly Shores, northwestern Indiana, 2009-11.

[Sampling site locations are shown in figure 3. mm/dd/yyyy, month, day, year; NGVD 29, National Geodetic Vertical Datum of 1929]

\begin{tabular}{|c|c|c|c|c|c|c|c|}
\hline $\begin{array}{l}\text { Sampling site } \\
\text { name }\end{array}$ & $\begin{array}{c}\text { Minimum } \\
\text { water level } \\
\text { (feet above } \\
\text { NGVD 29) }\end{array}$ & $\begin{array}{c}\text { Date of } \\
\text { occurrence } \\
\text { of minimum } \\
\text { water level } \\
\text { (mm/dd/yyyy) }\end{array}$ & $\begin{array}{c}\text { Median } \\
\text { water level } \\
\text { (feet above } \\
\text { NGVD 29) }\end{array}$ & $\begin{array}{c}\text { Maximum } \\
\text { water level } \\
\text { (feet above } \\
\text { NGVD 29) }\end{array}$ & $\begin{array}{c}\text { Date of } \\
\text { occurrence of } \\
\text { maximum } \\
\text { water level } \\
\text { (mm/dd/yyyy) }\end{array}$ & $\begin{array}{c}\text { Period of } \\
\text { record } \\
\text { (mm/dd/yyyy) }\end{array}$ & $\begin{array}{c}\text { Water level } \\
\text { fluctuation } \\
\text { (feet) }\end{array}$ \\
\hline W1 & 600.12 & $09 / 02 / 2010$ & 600.44 & 601.21 & $07 / 01 / 2011$ & $\begin{array}{l}12 / 17 / 2009 \text { to } \\
12 / 02 / 2011\end{array}$ & 1.09 \\
\hline W3 & 596.5 & $10 / 23 / 2010$ & 597.08 & 598.57 & $07 / 02 / 2011$ & $\begin{array}{l}12 / 18 / 2009 \text { to } \\
12 / 02 / 2011\end{array}$ & 2.07 \\
\hline
\end{tabular}



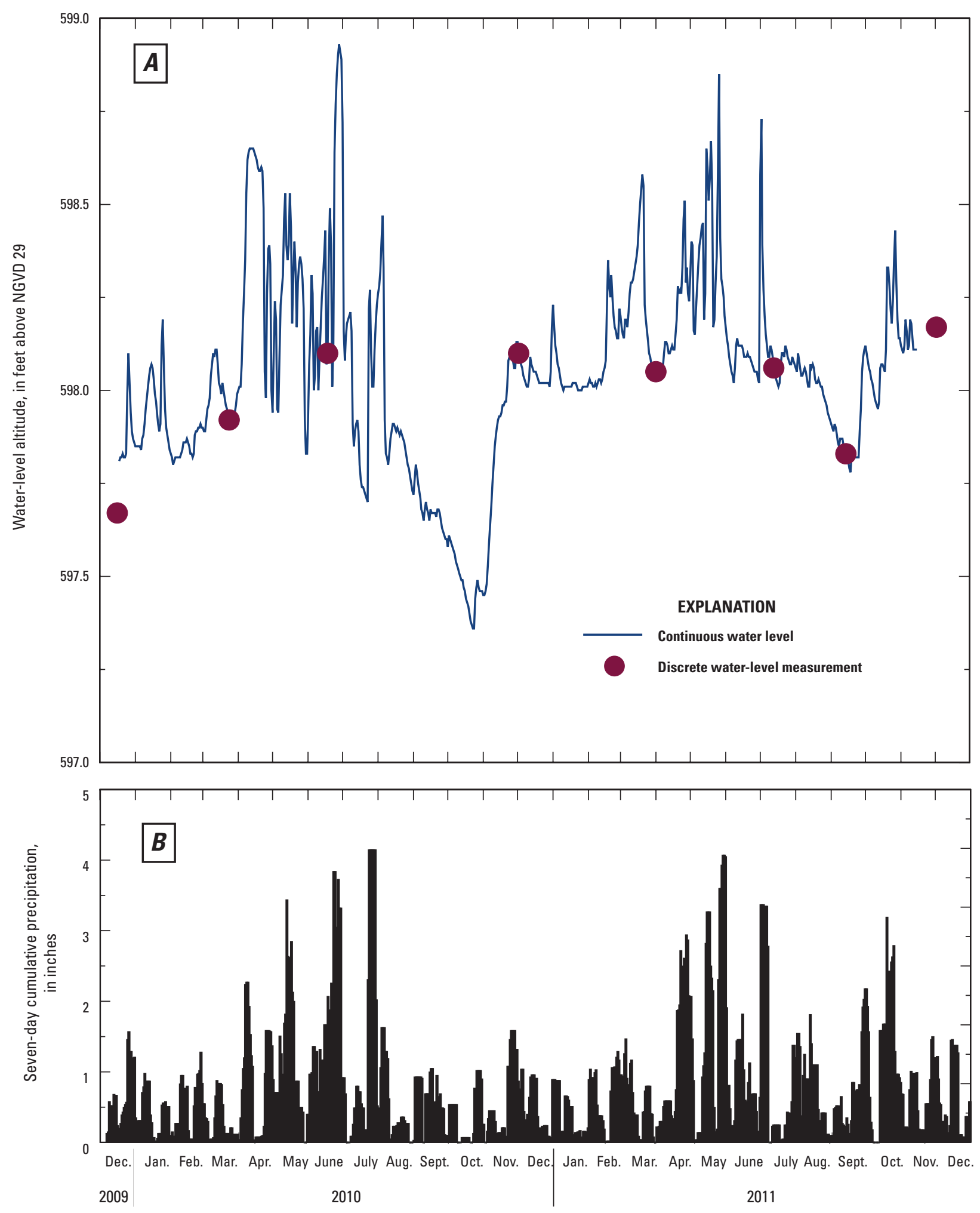

Figure 10. A, continuous water levels and water levels at the time of discrete sample collection at site W2 and $B, 7$-day cumulative precipitation. 
Table 10. Wetland cell response to a heavy rain event in Great Marsh at Beverly Shores, northwestern Indiana, June 2011.

[Sampling site locations are shown in figure 3. mm/dd/yyyy, month, day, year; NGVD 29, National Geodetic Vertical Datum of 1929]

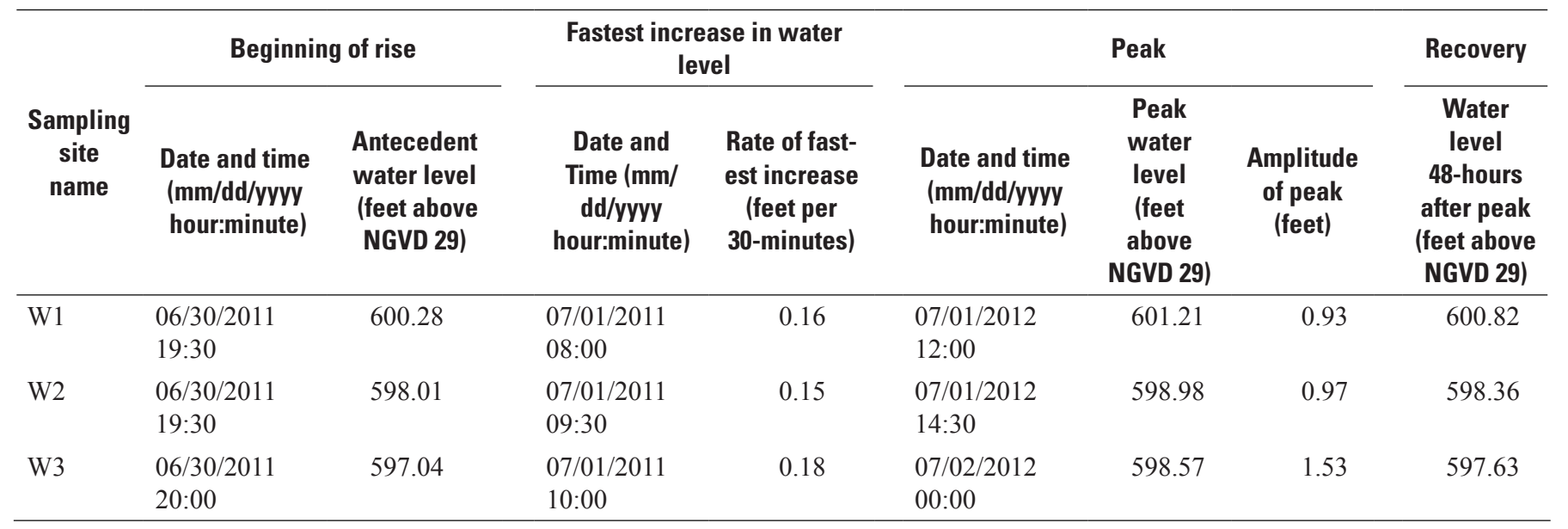

\section{Estimated Daily Loads of Septic Tank Indicator Compounds}

Total daily loads of seven septic tank indicator compounds moving downstream through the wetland cells were larger in spring and summer samples than in samples collected during the fall season (table 12). Total daily loads were estimated when flow measurements were available to provide information on the mass of compounds moving through the wetland. Loads were calculated by multiplying concentrations from discrete water samples by measured streamflow and a unit conversion factor. Median loads increased in downstream order, likely due to increased streamflow. The largest median loads were measured at site W3. Median loads were higher for samples collected in spring and summer than those collected in fall, corresponding with higher streamflow from the wetland cells during the spring and summer seasons.

Load estimates presented in this report contain some uncertainty owing to the quality of streamflow measurements and the small concentrations of the septic tank indicator compounds. Streamflow measurements were rated "poor" due to extremely shallow depths, low velocities, and uneven flow. Most estimated or detected concentrations were very small, often near the lower limits of the analytical equipment. Hydrologic conditions were generally stable at the time of sample collection, based on surface-water level changes during the date of sampling. Samples and streamflow measurements were not collected during any storm events.

\section{Wetland Sediment Accumulation of Organic Wastewater Compounds}

Five wetland sediment samples were analyzed for a total of 84 OWCs, PAHs, and SVOCs. Compounds with low solubility in water (and higher $\log \mathrm{K}_{\mathrm{OW}}$ values) are most likely to adsorb (bind) to sediments. Many OWCs detected in the discrete water samples (table 4) had $\log \mathrm{K}_{\mathrm{OW}}$ values of 4 or greater, indicating the potential for those compounds to adsorb to wetland sediments as water moves through the marsh (tables 4 and 5). Forty-one constituents were detected in at least 1 environmental wetland sediment sample, and 15 constituents were detected in all 5 wetland sediment samples (appendix 3). The five constituents detected with the greatest total mass in wetland sediment samples were beta-sitosterol, beta-stigmastanol, cholesterol, bis(2-ethylhexyl)phthalate, and phenol. With the exception of phenol $\left(\log \mathrm{K}_{\mathrm{OW}}=1.51\right)$, these compounds have high $\log \mathrm{K}_{\mathrm{OW}}$ values (greater than 8; table 4). Another group of commonly detected compounds was PAHs.

PAH compounds were detected in all five wetland sediment samples. Total PAH concentrations ranged from 300 to 7,300 micrograms per kilogram $(\mu \mathrm{g} / \mathrm{kg}$ ). No sample exceeded the commonly used consensus-based probable effect concentration (PEC) for total PAHs of 22,800 $\mu \mathrm{g} / \mathrm{kg}$ (McDonald and others, 2000). Five PAHs were detected in all five wetland sediment samples - phenanthrene, fluoranthene, pyrene, benzo[a] pyrene, and 2,6-dimethylnaphthalene. Other PAH compounds detected in one or more wetland sediment samples included 1,2-dimethylnaphthalene, 1,6-dimethylnaphthalene, 1-methyl9H-fluorene, 2-methylanthracene, 2-methylnaphthalene, 9,10-anthraquinone, 9H-fluorene, acenaphthene, acenaphthylene, anthracene, benzo[a]anthracene, benzo[b]fluoranthene, benzo[e]pyrene, benzo[ghi]perylene, and naphthalene.

Few literature sources provide comparable $\mathrm{PAH}$ data for wetland sediments, though lake sediment cores have been sampled extensively for these compounds. Total PAH concentrations from sediment samples from Lake Calumet, located south of metropolitan Chicago, Illinois (approximately $32 \mathrm{mi}$ from the study area) ranged from 4,900 to $20,000 \mu \mathrm{g} / \mathrm{kg}$ ( $\mathrm{Li}$ and others, 2003). A study of wetland sediments in the Elizabeth River, Virginia watershed reported total PAH concentrations ranging from 1,200 to $22,200 \mu \mathrm{g} / \mathrm{kg}$ (Kimbrough and Dickhut, 2006). Compared to these literature sources, PAH concentrations in wetland sediments from Great Marsh were relatively low. 



Figure 11. $A$, continuous water levels and $B$, hourly cumulative precipitation during a heavy rain event.

Multiple lines of evidence including comparison of source profiles, ratios of detections, and the similar character of the atmospheric deposition indicate that PAH compounds detected in Great Marsh are likely products of atmospheric deposition, rather than contributions from residential areas and roadways. Several PAH compounds detected in wetland sediments from upstream, residential, and restored wetland sites may have originated from fallout of atmospheric particulates from coal and other combustion, as described by Mastalerz and others (2001). A prior source characterization study of PAHs in the Chicago/Lake Michigan area determined that most of the total PAH concentrations in air samples from the region could be attributed to coal combustion, natural gas combustion, coke ovens, and vehicle emissions (Simcik and others, 1999). Multiple methods have been used to attribute (apportion) environmental PAH detections to their sources, including source-receptor modeling, mass-balance modeling, and ratio analysis (VanMetre and Mahler, 2010).

Concentrations of 12 parent PAH compounds in wetland sediment were examined and compared to previously published source profiles for coal combustion, vehicle-related, fuel oil combustion, wood burning, and coal tar sealcoat-related 
sources, as presented by VanMetre and Mahler (2010). The 12 PAHs used to prepare the profiles are phenanthrene, anthracene, fluoranthene, pyrene, benz[a]anthracene, chrysene, benzo[b]fluoranthene, benzo[k]fluoranthene, benzo[e]pyrene, benzo[a]pyrene, indeno[1,2,3-cd]pyrene, and benzo-[ghi] perylene. Eleven of the 12 parent PAH compounds included in the source profiles were detected in the wetland sediment sample collected at site R1; benzo[k]fluoranthene was not detected in this sample. The remaining four samples (collected at sites $\mathrm{U} 1, \mathrm{R} 1, \mathrm{~W} 2$, and W3) contained seven or fewer parent compounds used in the source profiles and were excluded from this comparison. Following methods outlined by VanMetre and Mahler (2010), "proportional PAH concentrations" were calculated by dividing reported or estimated concentrations of the individual PAHs by the summed concentration of the 12 parent compounds. Chi square values were calculated as the square of the difference in proportional PAH concentrations divided by the mean of the 2 values, summed for the $12 \mathrm{PAH}$ compounds. Similarity between profiles is indicated by minimization of the chi-square values. Values less than 0.1 indicate a close match to source profiles (VanMetre and Mahler, 2010). Calculation and comparison of chi square values indicate most similarity between PAHs detected in samples from site R1 and the source profile for coke oven emissions (chi square 0.51 ); however, the relatively high chi square values indicate that the PAHs are likely a mixture from multiple sources.

Ratios of PAH compounds can be used to distinguish between petroleum and combustion (pyrogenic) sources (Yunker and others, 2002; Neff, and others, 2005). Phenanthrene/anthracene (PH/AN) and fluoranthene/pyrene (FL/PY) ratios were calculated using detected and estimated concentrations from wetland sediment samples (table 13). Pyrogenic PAHs are formed when fuels and other organic matter are incompletely or inefficiently combusted or pyrolized (Battelle
Memorial Institute and others, 2003). Comparison of the PH/ $\mathrm{AN}$ and FL/PR ratios to previously published research corroborates the likely pyrogenic origin of the PAH contamination in the wetlands (Crane and others, 2010). The PH/AN ratio of pyrogenic PAH mixtures is generally less than 5, and the FL/ PY ratio usually approaches or exceeds 1 (Neff and others, 2005). These conditions were met for four of the five sediment samples analyzed (table 13). The PH/AN ratio calculated for the fifth sample (collected at U1) was 5.5.

Comparisons of PAH concentrations in wetland sediment samples to sediment quality target (SQT) guidelines indicate the potential for harmful effects on sediment-dwelling organisms at several sites. The Minnesota Level I and Level II SQT guidelines (table 13; Crane and Hennes, 2007) are similar to those used in Indiana to characterize sediment injury in the Grand Calumet River (MacDonald and others, 2000) for protection of benthic invertebrates. The SQT guidelines are consensus-based sediment quality guidelines developed in Minnesota and adopted by Wisconsin and other jurisdictions. (Crane and Hennes, 2007). They are a useful tool for assessing sediment quality conditions in a range of geographic areas (Crane and Hennes, 2007). Minnesota has designated two types of narrative SQTs: Level I and Level II. Level I SQTs are intended to identify contaminant concentrations below which harmful effects on sediment-dwelling organisms are unlikely to be observed. Level II SQTs are intended to identify contaminant concentrations above which harmful effects on sediment-dwelling organisms are likely to be observed (Crane and Hennes, 2007).

Concentrations of 13 priority PAH compounds targeted during wetland sediment analysis are compared to individual and total SQTs (table 13). For this comparison, total PAHs were calculated as the sum of detected and estimated concentrations for the 13 priority PAH compounds. Concentrations

Table 11. Water levels and streamflow at wetland spillways in Great Marsh at Beverly Shores, northwestern Indiana, 2009-11.

[Sampling site locations area shown in figure 3. mm/dd/yyyy, month, day, year; NGVD 29, National Geodetic Vertical Datum of 1929; n.m., not measured]

\begin{tabular}{|c|c|c|c|c|c|c|}
\hline \multirow[b]{2}{*}{$\begin{array}{c}\text { Date of } \\
\text { sample } \\
\text { collection } \\
\text { (mm/dd/yyyy) }\end{array}$} & \multicolumn{2}{|c|}{ Sampling site W1 } & \multicolumn{2}{|c|}{ Sampling site W2 } & \multicolumn{2}{|c|}{ Sampling site W3 } \\
\hline & $\begin{array}{c}\text { Water level } \\
\text { elevation } \\
\text { (feet above } \\
\text { NGVD29) }\end{array}$ & $\begin{array}{l}\text { Streamflow } \\
\text { (cubic feet } \\
\text { per second) }\end{array}$ & $\begin{array}{c}\text { Water level } \\
\text { elevation } \\
\text { (feet above } \\
\text { NGVD29) }\end{array}$ & $\begin{array}{l}\text { Streamflow } \\
\text { (cubic feet } \\
\text { per second) }\end{array}$ & $\begin{array}{c}\text { Water level } \\
\text { elevation } \\
\text { (feet above } \\
\text { NGVD29) }\end{array}$ & $\begin{array}{l}\text { Streamflow } \\
\text { (cubic feet } \\
\text { per second) }\end{array}$ \\
\hline $12 / 16 / 2009$ & 601.01 & 0.03 & 597.48 & 0.21 & 597.07 & 0.57 \\
\hline $03 / 24 / 2010$ & 600.37 & n.m & 597.91 & 0.62 & 597.11 & 0.830 \\
\hline 06/18/2010 & 600.38 & 0.12 & 598.08 & 0 & 597.33 & 3.24 \\
\hline $12 / 02 / 2010$ & 600.65 & 0.10 & 598.13 & 0.36 & 597.48 & 1.57 \\
\hline 04/01/2011 & 600.34 & n.m. & 598.06 & n.m & 597.08 & n.m \\
\hline 07/13/2011 & 600.55 & 0 & 598.03 & 0.33 & 597.1 & 0.36 \\
\hline 09/14/2011 & 600.45 & 0 & 596.76 & 0 & 596.76 & 0 \\
\hline $12 / 02 / 2011$ & 600.52 & n.m & 598.17 & n.m & 597.49 & n.m. \\
\hline
\end{tabular}



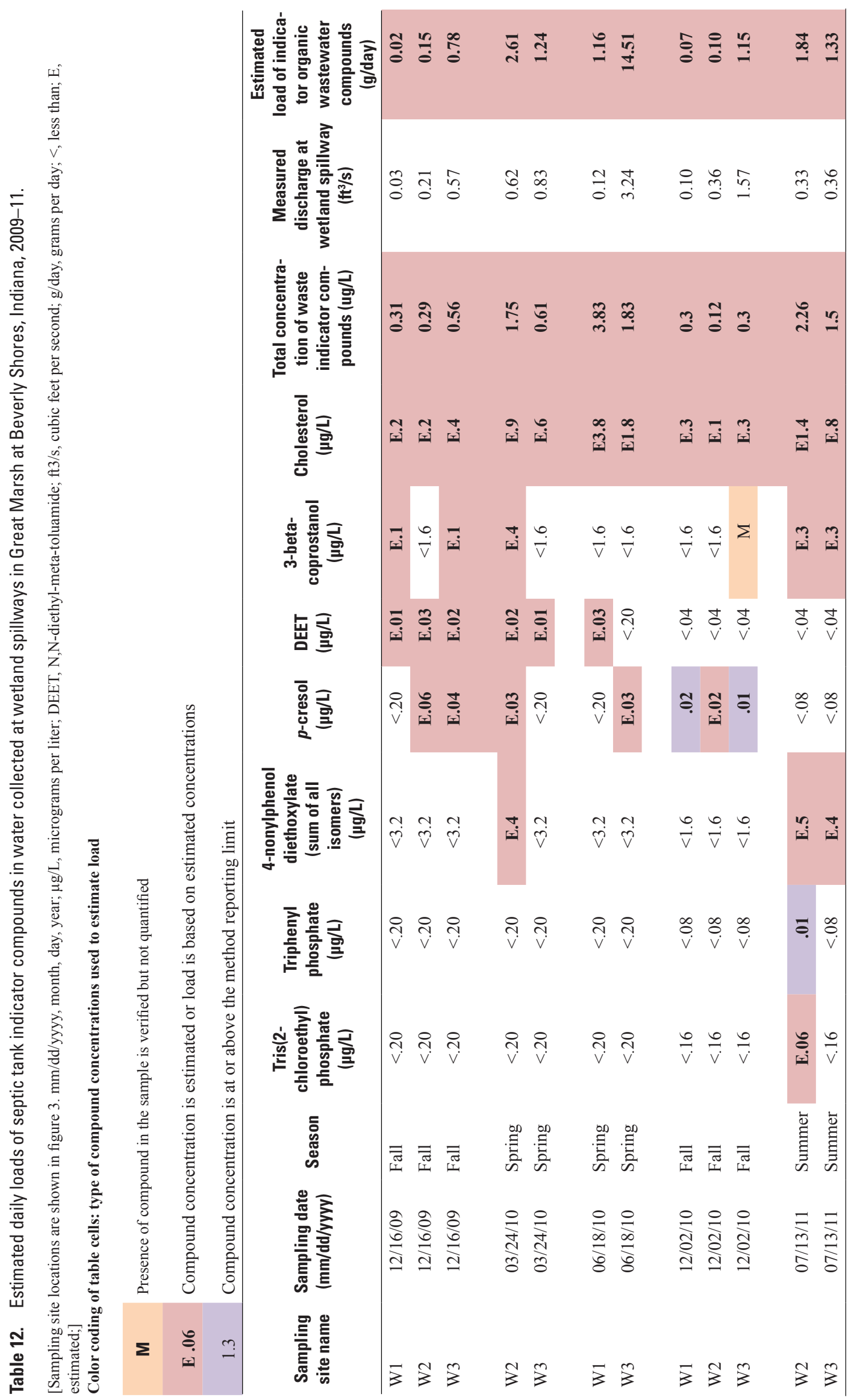
Table 13. Calculated total concentrations of 13 priority polycyclic aromatic hydrocarbon compounds and ratios of phenanthrene to anthracene and fluoranthene to pyrene in wetland-sediment samples collected in and near Great Marsh at Beverly Shores, northwestern Indiana, 2011, and comparison to available Sediment Quality Targets.

[Sampling site locations are shown in figure 3.

Shaded entries indicate exceedance of Minnesota Sediment Quality Targets.

\section{Exceedance of Level I sediment quality target: indicates harmful effects on sediment-dwelling organisms are possible \\ 440 Exceedance of Level II sediment quality target: indicates harmful effects on sediment-dwelling organisms are likely to be observed}

PAH, polycylic aromatic hydrocarbon; SQT, sediment quality target; $\mu \mathrm{g} / \mathrm{kg}$, microgram per kilogram; E, Estimated; $<$, less than]

\begin{tabular}{|c|c|c|c|c|c|c|c|}
\hline \multirow{2}{*}{ PAH compound } & \multicolumn{5}{|c|}{ Sampling site name } & \multirow{2}{*}{$\begin{array}{c}\text { Level I } \\
\text { SOT }\end{array}$} & \multirow{2}{*}{$\begin{array}{l}\text { Level II } \\
\text { SOT }\end{array}$} \\
\hline & U1 & R1 & $\mathbf{R 2}$ & W2 & W3 & & \\
\hline 2-methylnaphthalene $(\mu \mathrm{g} / \mathrm{kg})$ & E 20 & E 20 & $<70$ & E 100 & $<140$ & 20 & 200 \\
\hline 9H-fluorene $(\mu \mathrm{g} / \mathrm{kg})$ & E 68 & 340 & $<33$ & E 17 & $<53$ & 77 & 540 \\
\hline Acenaphthene $(\mu \mathrm{g} / \mathrm{kg})$ & E 38 & E 99 & $<33$ & $<58$ & $<53$ & 7 & 89 \\
\hline Acenaphthylene ( $\mu \mathrm{g} / \mathrm{kg})$ & $<113$ & 440 & $<33$ & $<58$ & $<53$ & 6 & 130 \\
\hline Anthracene $(\mu \mathrm{g} / \mathrm{kg})$ & 20 & 50 & $<70$ & 40 & $<140$ & 57 & 850 \\
\hline Benzo[a]anthracene $(\mu \mathrm{g} / \mathrm{kg})$ & $<180$ & 1,100 & $<33$ & 320 & $<53$ & 110 & 1,100 \\
\hline Benzo[a]pyrene $(\mu \mathrm{g} / \mathrm{kg})$ & 50 & 120 & 30 & 70 & E 30 & 150 & 1,500 \\
\hline Chrysene $(\mu \mathrm{g} / \mathrm{kg})$ & $<180$ & 1,100 & $<35$ & $<200$ & $<53$ & 170 & 1,300 \\
\hline Dibenzo[a,h]anthracene $(\mu \mathrm{g} / \mathrm{kg})$ & $<110$ & $<200$ & $<33$ & $<58$ & $<53$ & 33 & 140 \\
\hline Fluoranthene $(\mu \mathrm{g} / \mathrm{kg})$ & 120 & 280 & 90 & 170 & 80 & 420 & 2,200 \\
\hline Naphthalene $(\mu \mathrm{g} / \mathrm{kg})$ & 40 & 70 & E 20 & 110 & $<140$ & 180 & 560 \\
\hline Phenanthrene $(\mu \mathrm{g} / \mathrm{kg})$ & 110 & 170 & 70 & 160 & E 50 & 200 & 1,200 \\
\hline Pyrene $(\mu \mathrm{g} / \mathrm{kg})$ & 90 & 190 & 70 & 160 & 60 & 200 & 1,500 \\
\hline $\begin{array}{l}\text { Total (sum of detected and estimated } \\
\text { concentrations) }\end{array}$ & 556 & 3,979 & 280 & 1,147 & 220 & 1,600 & 23,000 \\
\hline Phenanthrene to anthracene ratio & 5.5 & 3.4 & $<1$ & 4 & $<.36$ & & \\
\hline Fluoranthene to pyrene ratio & 1.33 & 1.47 & 1.29 & 1.06 & 1.33 & & \\
\hline
\end{tabular}

of 2-methylnaphthalene and benzo[a]anthracene in the sample from restored wetland site $\mathrm{W} 2,9 \mathrm{H}$-fluorene at upstream site $\mathrm{U} 1$, and $9 \mathrm{H}-$ fluorene, benzo[a]anthracene, and chrysene at residential site R1 exceeded the Minnesota Level I SQTs for those compounds, indicating the potential for harmful effects on sediment-dwelling organisms. In addition, concentrations of 9H-fluorene and benzo[a]anthracene at site R1 exceeded the Level II SQT for those compounds, indicating that harmful effects on sediment-dwelling organisms are more likely to be observed. These comparisons are not conclusive; they are based on results from one sampling event and must be verified with additional analyses and assessment of benthic invertebrate communities to verify these indications.

\section{Potential for Biodegradation of Model Organic Wastewater Compounds in Sediment}

Results of laboratory microcosm biodegradation studies involving study area sediments and several model compound types representative of OWCs, including a synthetic estrogen, an alkyl phenol detergent, a common antibacterial agent (TCC), and an endocrine disruptor (BPA), are summarized in table 14. Little evidence of biotransformation of $17 \alpha$-ethinylestradiol (EE2) was observed except in microcosms containing sediment from site R2, which may indicate the potential for microbial communities to acclimate to septic discharge. The highly branched 4-nonylphenol isomers generally were recalcitrant to biotransformation and would tend to accumulate in wetland sediments. TCC and BPA were incompletely biotransformed, but only under oxic conditions. Oxygen availability in water and sediment may be a limiting factor in the persistence of many OWCs in wetland sediment. Field measurements of dissolved oxygen varied widely throughout the study period, ranging from $0.1 \mathrm{mg} / \mathrm{L}$ to 13.3 $\mathrm{mg} / \mathrm{L}$ (appendix table 1-1). Larger concentrations of dissolved oxygen (greater than $5 \mathrm{mg} / \mathrm{L}$ ) coincided with lower water temperatures, occurring primarily when water temperature was less than $10^{\circ} \mathrm{C}$. Results of the sediment biodegradation studies are summarized in table 14. Results for each model wastewater contaminant compound are discussed in following sections. 
Table 14. Results of microcosm biodegradation experiments for 17a-ethinylestradiol, 4-nonylphenol, triclocarban, and bisphenol A in wetland sediment samples collected in and near Great Marsh at Beverly Shores, northwestern Indiana, 2011.

[Sampling site locations are shown in figure $3 .{ }^{14} \mathrm{C}$ radiolabeled carbon isotope; ${ }^{14} \mathrm{C}-\mathrm{OWC}$, radiolabeled organic waste compound; ${ }^{14} \mathrm{CO}_{2}$, radiolabeled carbon dioxide; mineralization rate, estimated linear rate of ${ }^{14} \mathrm{C}$-OWC mineralization estimated for period of increasing ${ }^{14} \mathrm{CO}_{2}$ recovery, only; EE2, 17 $\alpha$-ethinylestradiol; 4-NP, 4-nonylphenol; TCC, triclocarban; BPA, bisphenol A; n.s., denotes no significant recovery (total recovery less than 1 percent) in any treatment microcosm]

\begin{tabular}{|c|c|c|c|c|c|c|}
\hline${ }^{14} \mathrm{C}-\mathrm{OWC}$ & $\begin{array}{l}\text { Sampling } \\
\text { site name }\end{array}$ & $\begin{array}{c}\text { Atmospheric } \\
\text { treatment }\end{array}$ & $\begin{array}{c}\text { Incubation time } \\
\text { (days) }\end{array}$ & $\begin{array}{r}\text { Detection } \\
\text { frequency } \\
\text { (percent) }\end{array}$ & $\begin{array}{l}{ }^{14} \mathrm{CO}_{2} \text { recovery, } \\
\text { (reported in percent } \\
\text { concentration of } \\
\text { headspace); } \\
\text { range of percent } \\
\text { recoveries in } \\
\text { parenthesis }\end{array}$ & $\begin{array}{c}{ }^{14} \mathrm{C}-\mathrm{OWC} \\
\text { mineralization } \\
\text { rate } \\
\text { (percent per day) }\end{array}$ \\
\hline \multirow{6}{*}{ EE2 } & \multirow{2}{*}{ U1 } & OXIC & 230 & $0 / 5$ & n.s. & n.s. \\
\hline & & ANOXIC & 230 & $0 / 5$ & n.s. & n.s. \\
\hline & \multirow{2}{*}{$\mathrm{R} 2$} & OXIC & 230 & $2 / 5$ & $27 \pm 8(18-35)$ & $0.11 \pm 0.03$ \\
\hline & & ANOXIC & 230 & $0 / 5$ & n.s. & n.s. \\
\hline & \multirow{2}{*}{ W2 } & OXIC & 230 & $0 / 5$ & n.s. & n.s. \\
\hline & & ANOXIC & 230 & $0 / 5$ & n.s. & n.s. \\
\hline \multirow{6}{*}{ 4-NP } & \multirow{2}{*}{ U1 } & OXIC & 229 & $4 / 5$ & $2 \pm 1(1-2)$ & $0.009 \pm 0.004$ \\
\hline & & ANOXIC & 229 & $0 / 5$ & n.s. & n.s. \\
\hline & \multirow{2}{*}{$\mathrm{R} 2$} & OXIC & 229 & $2 / 5$ & $2 \pm 1(1-3)$ & $0.009 \pm 0.004$ \\
\hline & & ANOXIC & 229 & $0 / 5$ & n.s. & n.s. \\
\hline & \multirow{2}{*}{ W2 } & OXIC & 229 & $3 / 5$ & $5 \pm 3(1-7)$ & $0.02 \pm 0.01$ \\
\hline & & ANOXIC & 229 & $0 / 5$ & n.s. & n.s. \\
\hline \multirow{6}{*}{ TCC } & \multirow{2}{*}{ U1 } & OXIC & 6 & $2 / 5$ & $4 \pm 2(2-5)$ & $0.66 \pm 0.33$ \\
\hline & & ANOXIC & 211 & $0 / 5$ & n.s. & n.s. \\
\hline & \multirow{2}{*}{$\mathrm{R} 2$} & OXIC & 6 & $3 / 5$ & $6 \pm 2(4-9)$ & $1.0 \pm 0.33$ \\
\hline & & ANOXIC & 211 & $0 / 5$ & n.s. & n.s. \\
\hline & \multirow{2}{*}{ W2 } & OXIC & 6 & $4 / 5$ & $7 \pm 2(4-10)$ & $1.2 \pm 0.33$ \\
\hline & & ANOXIC & 211 & $0 / 5$ & n.s. & n.s. \\
\hline \multirow{6}{*}{ BPA } & \multirow{2}{*}{ U1 } & OXIC & 12 & $5 / 5$ & $8 \pm 4(2-11)$ & $0.66 \pm 0.33$ \\
\hline & & ANOXIC & 229 & $4 / 5$ & $2 \pm 1(1-3)$ & $0.009 \pm 0.004$ \\
\hline & \multirow{2}{*}{$\mathrm{R} 2$} & OXIC & 12 & $5 / 5$ & $12 \pm 6(2-16)$ & $1.0 \pm 0.5$ \\
\hline & & ANOXIC & 229 & $2 / 5$ & $1 \pm 1(1-2)$ & $0.004 \pm 0.004$ \\
\hline & \multirow{2}{*}{ W2 } & OXIC & 12 & $5 / 5$ & $8 \pm 1 \quad(6-9)$ & $0.66 \pm 0.08$ \\
\hline & & ANOXIC & 229 & $4 / 5$ & $2 \pm 1(2-3)$ & $0.009 \pm 0.004$ \\
\hline
\end{tabular}


EE2 is a synthetic estrogen pharmaceutical used primarily for birth control. Substantial biodegradation of carbon-14 labeled $17 \alpha$-ethinylestradiol $\left({ }^{14} \mathrm{C}\right.$-EE2) was observed only in oxic microcosms containing sediment from site R2 (table 14). The recovery of ${ }^{14} \mathrm{CO}_{2}$ was attributed to microbial activity, because no substantial recovery of ${ }^{14} \mathrm{CO}_{2}$ (recovery less than 1 percent of theoretical) was observed in autoclaved control microcosms. Recovery of ${ }^{14} \mathrm{CO}_{2}$ is interpreted as explicit evidence of microbial cleavage of the steroid " $\mathrm{A}$ " ring and loss of endocrine activity, as demonstrated previously using the YES assay (Layton and others, 2000; Jürgens and others, 2002).

The poor mineralization of EE2 observed in this study (table 14) is consistent with previous reports documenting poor biodegradation of EE2 in some rivers in the United Kingdom (Jürgens and others, 2002) and the delayed onset of aerobic mineralization of ${ }^{14} \mathrm{C}$-EE2 in sediment in Boulder Creek, Colorado that is affected by an upstream wastewater treatment plant (Writer and others, 2011). The lack of evidence for mineralization of EE2 in this study under anoxic conditions is consistent with the substantially lower rates of biodegradation of aromatic contaminant compounds under anoxic conditions compared with oxic conditions.

An important observation of this study was that substantial ${ }^{14} \mathrm{C}$-EE2 mineralization observed in microcosms containing sediment collected from site R2 may indicate acclimation of microbial communities to septic discharge. Of the three sediment samples assessed from the study area, those from site $\mathrm{R} 2$ are in closest proximity to residential impacts including septic system discharge. Thus, the mineralization of ${ }^{14} \mathrm{C}$ -

EE2 in sediments collected from this location may indicate the adaptation and acclimation of the indigenous microbial community to septic discharge and the resultant selection of a microbial capability for EE2 biodegradation. Wastewater effluent may enhance in situ biodegradation of hormone contaminants by introducing degradative populations or by stimulating the indigenous microorganisms through increased supply of nutrients and co-metabolites (Bradley and others, 2009).

\section{4-Nonylphenol (4-NP)}

Alkylphenol contaminants, like 4-NP, are ubiquitous in wastewater (Lintelmann and others, 2003; Kolpin and others, 2002), have been reported in effluent-impacted streams at concentrations up to $644 \mu \mathrm{g} / \mathrm{L}$ (Sole and others, 2000; Ying and others, 2002), and have been detected in the majority of investigated surface-water systems (Bradley and others, 2008). Nonylphenol-based compounds are the primary alkylphenol contaminants detected in stream systems impacted by wastewater treatment plant effluent (Kolpin and others, 2002), because nonylphenol ethoxylates constitute approximately 82 percent of the world production of alkylphenol ethoxylate (Lintelmann and others, 2003). The widespread occurrence of 4-NP in the environment generally is attributable to microbial transformation of effluent-associated nonylphenol ethoxylates to 4-NP in anoxic, surface-water sediments (Vazquez-Duhalt and others, 2005).

Isomers of 4-NP and other alkylphenol contaminants exhibit variable estrogenic activity related to their individual structures. Estrogenicity can vary by a factor of 10 depending on the structure of the alkyl chain, with increased branching in the benzylic position associated with increased estrogenicity (Kim and others, 2004; Routledge and Sumpter, 1996). The biodegradability of 4-NP is reported to decrease with increasing degree of nonyl-group branching (Corvini and others, 2004; Corti and others, 1995; Van Ginkel, 1996). In contrast, efficient biodegradation has been reported for the linear chain isomer (4- $n$-NP) (Corvini and others, 2004; Corti and others, 1995; Van Ginkel, 1996; Bradley and others, 2008).

Mineralization of ${ }^{14} \mathrm{C}-4-\mathrm{NP}$ was observed only at trace in this study and only under oxic conditions (table 14). The poor biodegradation potential is consistent with a number of reports of 4-NP biorecalcitrance in soil and sediments (Ying and others, 2002; Ferguson and Brownawell, 2003; Shang and others, 1999). Efficient biodegradation of the linear chain, 4- $n$-NP isomer has been reported previously in wastewaterimpacted stream sediments (Bradley and others, 2008). The highly branched 4-NP isomer used as a model substrate in this study was chosen specifically to provide insight into the overall environmental recalcitrance of a 4-NP isomeric mixture. The results of this study indicate that the highly branched 4-NP isomers, at least, will exhibit general biorecalcitrance and a tendency to accumulate in sediments within the wetland complex at INDU.

No accumulation of ${ }^{14} \mathrm{CO}_{2}$ was detected (minimum detection limit equals 1 percent of theoretical) in any of the collected sediments when incubated under anoxic conditions. Under anoxic conditions, the sediments from all three locations were methanogenic. The lack of evidence for mineralization of ${ }^{14} \mathrm{C}$ - 4-NP in this study under anoxic conditions is consistent with the substantially lower rates of biodegradation of aromatic contaminant compounds under anoxic conditions compared with oxic conditions. This result is also consistent with recent findings that even the relatively biodegradable, linear chain 4- $n$-NP isomer is recalcitrant under anoxic conditions (Bradley and others, 2008). 


\section{Triclocarban (TCC)}

TCC and triclosan are common antibacterial ingredients in a wide range of personal care products including cosmetics, antibacterial soaps, and toothpaste. These compounds have been documented in wastewater-impacted surface waters (Coogan and others, 2007, 2008; Halden and Paull, 2004, 2005; Heidler and others, 2006; Sapkota and others, 2007; Xie and others, 2008). Both compounds have been shown to enhance the activity of estrogenic and androgenic compounds (Ahn and others, 2008; Chen and others, 2008) and to bioaccumulate in aquatic biota (Coogan and others, 2007; 2008).

Substantial biodegradation of ${ }^{14} \mathrm{C}$-TCC was observed in oxic microcosms containing sediment from all three sites (table 14). Production of ${ }^{14} \mathrm{CO}_{2}$ (indicating degradation of ${ }^{14} \mathrm{C}$-TCC ) was attributed to microbial activity in the sediments, because no substantial recovery of ${ }^{14} \mathrm{CO}_{2}$ was observed in autoclaved control microcosms. Oxic TCC mineralization initially was efficient, with mean initial linear rates ranging from 0.66 to 1.2 percent per day over the first 6 days of incubations (table 14). TCC biodegradation under oxic conditions is consistent with previous findings (Ying and others, 2007); however, no further mineralization was observed after 6 days, and the final recovery of the ${ }^{14} \mathrm{C}$-radiolabel as ${ }^{14} \mathrm{CO}_{2}$ was 10 percent of theoretical or less.

These results suggest that, although biodegradation of TCC can be substantial in the INDU wetland sediments under oxic conditions, TCC released to the environment may quickly become relatively unavailable for biological alteration, perhaps due to sorption or to reduced oxygen supply and limited aerobic activity in organic-enriched sediment environments. The lack of evidence for ${ }^{14} \mathrm{C}-\mathrm{TCC}$ mineralization under anoxic conditions is consistent with the former hypothesis and indicates that TCC will be relatively biorecalcitrant in settings where oxygen supply may become limited. Lack of persistence under anaerobic soil conditions and rapid partitioning to soil and sediment have been reported previously (Ying and others, 2007).

\section{Bisphenol A (BPA)}

BPA is used in the manufacture of polycarbonate plastics and epoxy resins. BPA is a demonstrated endocrine disruptor (xenoestrogenic activity) and widely documented in the environment (Cousins and others, 2002; Staples and others, 1998). A number of studies have demonstrated rapid biodegradation of BPA in a variety of environmental matrices (see for review, Cousins and others, 2002; Staples and others, 1998).

Substantial biodegradation of ${ }^{14} \mathrm{C}-\mathrm{BPA}$ was observed in oxic microcosms containing sediment from all three sites (table 14). The recovery of ${ }^{14} \mathrm{CO}_{2}$ observed in this study was attributed to microbial activity, because no substantial recovery of ${ }^{14} \mathrm{CO}_{2}$ was observed in autoclaved control microcosms. Oxic BPA mineralization was efficient, with mean initial linear rates ranging from 0.66 to 1.0 percent per day over the first 12 days of incubations (table 14); however, no further mineralization was observed after 12 days, and the final recovery of ${ }^{14} \mathrm{C}$-radiolabeled as ${ }^{14} \mathrm{CO}_{2}$ was 16 percent of theoretical or less.

As was the case for TCC, these results suggest that, while biodegradation of BPA can be substantial in the INDU wetland sediments under oxic conditions, BPA released to the environment may quickly become relatively unavailable for biological alteration, perhaps due to sorption or to reduced oxygen supply and limited aerobic activity in organic-enriched sediment environments. The limited ${ }^{14} \mathrm{C}$-BPA mineralization observed in this study under anoxic conditions is consistent with the former hypothesis. The observed rates of ${ }^{14} \mathrm{C}$-BPA mineralization under anoxic conditions were two-to-three orders of magnitude slower than those under oxic conditions. These results indicate that oxygen supply is a fundamental control on the efficiency of BPA biodegradation in the wetland sediments at INDU.

\section{Summary and Conclusions}

Extensive restoration has been done at Great Marsh of the Indiana Dunes National Lakeshore in Beverly Shores, Indiana since 1999. The National Park Service was interested in acquiring information regarding the water quality of the restored wetlands, including the effects of nearby residential onsite wastewater treatment (septic systems). The U.S. Geological Survey assessed the water quality of Great Marsh from 2009-11 to document the presence and extent of these effects. A multiphase assessment was conducted, examining surface water and sediments in and near the restored wetlands. Discrete water samples, passively collected water samples, and wetland sediment samples were analyzed and used to determine the degree and extent of impacts, along with possible fates of organic wastewater compounds (OWCs) entering the wetland.

Sampling sites were selected to represent different environments and water sources in the area, including upstream sites, residential sites, and sites within the restored wetland. Discrete water samples and passive sampler extracts were analyzed for 69 OWCs. A total of 52 OWCs were detected in discrete water samples at 1 or more sites. OWCs were detected at all sites, but concentrations were generally small; 95 percent were less than 2.1 micrograms per liter. Six compounds were detected at concentrations greater than 2.1 micrograms per liter (beta-sitosterol, cholesterol, beta-stigmastanol, bis2-ethylhexylphthalate, 2-beta coprostanol, and 4-nonylphenol diethoxylate). Discrete water samples indicated the presence of seven of eight organic compounds determined to be reliable indicators of wastewater in aqueous environments. Detections were geographically widespread, but generally small. Analysis of passive time-integrated samples showed the presence of all eight compounds. Some compounds, such as the sterols 3-beta-coprostanol, beta-sitosterol, and beta-stigmastanol were detected in higher percentages in water from upstream 
sites than in samples from the residential area. These detection frequencies indicate the possibility of natural or uncharacterized upstream sources of these compounds. Total polycyclic aromatic hydrocarbon (PAH) concentrations in 9 of 67 discrete water samples exceeded Indiana's continuous criterion concentration for protection of human health for total PAHs $(0.31$ micrograms per liter). The standard was exceeded by three of eight samples collected at site W1 and two of eight samples collected at sites U1, R1, and R3.

Two extended deployments of passive polar organic chemical integrative samplers (POCIS) allowed detection of three OWCs at lower concentrations than possible with discrete sampling. Isopropyl benzene (a solvent), caffeine (a pharmaceutical), and hexahydrohexamethyl cyclopentabenzopyran (a fragrance), were detected in half or more of the POCIS samples, but not in any of the 67 discrete water samples. A Yeast Estrogen Screen assay detected measurable estrogenicity in the POCIS samples from the restored wetland cell at W3 in both the April and November-December 2011 deployments and at residential site R2 and upstream site U1 in the November-December 2011 deployment only.

Water levels in the restored wetland cells were monitored continuously using vented submersible pressure transducers. The maximum range of water-level fluctuation ( 2.07 feet) over the study period was measured at site W3. Wetland response to storm events and seasonal patterns in water levels were studied. Surface-water levels in the wetland cells responded quickly to precipitation and receded to near pre-precipitation levels within 2 days following large rainfall events. Following a heavy storm of 3.34 inches of rainfall from June 30 to July 1,2011 , surface-water levels at site W3 rose by 1.53 feet, then fell by 0.94 feet within 48 hours.

Total daily loads of seven septic tank indicator compounds were estimated for samples collected at wetland spillways when flow measurements were available. Median loads of septic tank indicator compounds increased in downstream order - the largest median loads were measured at site W3. Median total loads of septic tank indicator compounds were higher for samples collected in spring and summer than for those collected in fall, corresponding with higher streamflow from the wetland cells during the spring and summer seasons.

Many of the OWCs targeted by this study are relatively insoluble in water, and may bind to sediments in the wetland. Sediment samples were analyzed for 84 OWCs, PAHs, and semivolatile organic compounds. PAHs were frequently detected in wetland sediment samples. Further analysis and source apportionment models indicate that those PAHs are mostly pyrogenic and are likely products of atmospheric deposition, rather than contributions from residential areas and roadways. Sediment quality target guidelines were exceeded for many PAH compounds, indicating potential for injury to sediment-dwelling organisms.

Wetland sediments have potential for extensive microbial activity capable of transforming organic compounds and altering water chemistry as it moves through the marsh. Potential for the wetland sediments to biodegrade OWCs was investigated through use of microcosms with sediment from three study sites and radiolabeled model compounds incubated in oxic and anoxic environments. Biotransformation of 17 $\alpha$-ethinylestradiol was observed only in microcosms containing sediment from site R2, which may indicate the potential for microbial communities to acclimate to septic discharge. The highly branched 4-nonylphenol isomers generally were recalcitrant to biotransformation and would tend to accumulate in wetland sediments. Triclocarban and bisphenol A were incompletely biotransformed but only under oxic conditions. Oxygen availability in water and sediment may be a limiting factor in the persistence of many OWCs in wetland sediment.

The NPS restoration of Great Marsh has focused on (1) increasing biological diversity and habitat for native plants and migratory-birds, (2) improving recreational opportunities, and (3) managing runoff to Lake Michigan and associated beaches (National Park Service, 2006) Regarding focus area 1 , detections reported in this study provide a characterization of the low-level environmental occurrence of a wide variety of organic wastewater compounds in and near restored wetlands of Great Marsh near Beverly Shores, Ind. Their impacts to biological communities of the wetlands including benthic invertebrates, amphibians, and waterfowl are unknown but merit further investigation as time and resources permit. In terms of focus area 3, managing runoff to Lake Michigan, the study indicates that the wetland cells are providing some level of favorable runoff treatment, because the average number of OCWs was lowest at W3 - the outlet of the most downstream wetland cell. The "treatment" of runoff in the restored wetlands is indicated by the sorption of many OWCs onto wetland sediments. The wetland cells also slow water flow from upstream OWC sources. This enables the sediment associated OWCs to settle in the restored wetlands and increase the overall residence time of OWCs in the wetlands, thereby enhancing the potential for biodegradation of the compounds. 


\section{References Cited}

Ahn, K.C., Zhao, B., Chen, J., Cherednichenko, G., Snmarti, E., Denison, M.S., Lasley, B., Pessah, I.N., Kultz, D., Chang, D.P., Gee, S.J., and Hammock, B.D., 2008, In vitro activities of the antimicrobials triclocarban, its analogs, and triclosan in bioassay screens: receptor-based bioassay screens: Environmental Health Perspectives, v. 116, p. $1203-1210$.

Alvarez, D.A., 2010, Guidelines for the use of the semipermeable membrane device (SPMD) and the polar organic chemical integrative sampler (POCIS) in environmental monitoring studies: U.S. Geological Survey Techniques and Methods book 1, chap. D4, 28 p.

Alvarez, D.A., Cranor, W.L., Perkins, S.D., Clark, R.C., and Smith, S.B., 2008, Chemical and toxicological assessment of organic contaminants in surface water using passive samplers: Journal of Environmental Quality, v. 37, p. 1024-1033.

Alvarez, D.A., Cranor, W.L., Perkins, S.D., Schroeder, V.L., Werner, S.L., Furlong, E.T., Kain, D., and Brent, R., 2008, Reconnaissance of persistent and emerging contaminants in the Shenandoah and James River Basins, Virginia, during spring of 2007: U.S. Geological Survey Open-File Report 2008-1231, $19 \mathrm{p}$.

Alvarez, D.A., Huckins, J.N., Petty, J.D., Jones-Lepp, T.L., Stuer-Lauridsen, F., Getting, D.T., Goddard, J.P., and Gravell, A., 2007, Tool for monitoring hydrophilic contaminants in water: polar organic chemical integrative sampler (POCIS), chap. 8 of Greenwood, R., Mills, G., and Vrana, B., ed., Passive sampling techniques in environmental monitoring: Comprehensive Analytical Chemistry, Elsevier, v. 48, p. 171-197.

Alvarez, D.A., Petty, J.D., Huckins, J.N., Jones-Lepp, T.L., Getting, D.T., Goddard, J.P., and Manahan, S.E., 2004, Development of a passive, in situ, integrative sampler for hydrophilic organic contaminants in aquatic environments: Environmental Toxicology Chemistry, v. 23, p. 1,6401,648 .

Battelle Memorial Institute, Earth Tech, Inc., and NewFields, Inc., 2003, Chemical fingerprinting of PAHs in sedimentsrecognizing the contribution of urban background, app. A, of Sediment, v. II of Guidance for environmental background analysis: Washington, D.C., Naval Facilities Engineering Command, User's Guide UG-2054-ENV, accessed Nov. 15, 2012, at https://portal.navfac.navy.mil/portal/page/ portal/navfac/navfac_ww_pp/navfac_nfesc_pp/environmental/erb/resourceerb/ug-2054-sed-guide.pdf.
Beaty, J.E., 1994, Water resource availability in the Lake Michigan Region, Indiana: Indiana Department of Natural Resources, Division of Water, Water Resource Assessment 94-4, $257 \mathrm{p}$.

Bhattacharyya, G.K., and Johnson, R.A., 1977, Statistical concepts and methods: New York, John Wiley and Sons, 639 p.

Bradley, P.M., Chapelle, F.H., and Landmeyer, J.E., 2001, Effect of redox conditions on MTBE biodegradation in surface water sediments: Environmental Science and Technology, v. 35, p. 4643-4647.

Bradley, P.M., Landmeyer, J.E., and Chapelle, F.H., 2002, TBA biodegradation in surface-water sediments under aerobic and anaerobic conditions: Environmental Science and Technology, v. 36, p. 4087-4090.

Bradley, P.M., Barber, L.B., Kolpin, D.W., McMahon, P.B., and Chapelle, F.H., 2007, Biotransformation of caffeine, cotinine, and nicotine in stream sediments: Implications for use as wastewater indicators: Environmental Toxicology and Chemistry, v. 26, p. 1116-1121.

Bradley, P.M., Barber, L.B., Kolpin, D.W., McMahon, P.B., and Chapelle, F.H., 2008, Potential for 4-n-nonylphenol biodegradation in stream sediments: Environmental Toxicology and Chemistry, v. 27, p. 260-265.

Bradley, P.M., Barber, L.B., Chapelle, F.H., Gray, J.L., Kolpin, D.W., and McMahon, P.B., 2009, Biodegradation of $17 \beta$-estradiol, estrone and testosterone in stream sediments: Environmental Science and Technology, v. 43, p. 1902-1910.

Burkhardt, M.R., Zaugg, S.D., Smith, S.G., and ReVello, R.C., 2006, Determination of wastewater compounds in sediment and soil by pressurized solvent extraction, solid-phase extraction, and capillary-column gas chromatography/ mass spectrometry: U.S. Geological Survey Techniques and Methods, book 5, chap B2, 40 .

Buszka, P.M., Cohen, D.A., Lampe, D.C., and Pavlovic, N.B., 2011, Relation of hydrologic processes to groundwater and surface-water levels and flow directions in a dune-beach complex at Indiana Dunes National Lakeshore and Beverly Shores, Indiana: U.S. Geological Survey Scientific Investigations Report 2011-5073, 75 p.

Chapelle, F.H., 2001, Ground-water microbiology and geochemistry (2nd ed.): New York, John Wiley and Sons, 477 p., definition accessed May 3, 2013 at http://toxics.usgs.gov/ definitions/microcosm.html

Chen, J., Ahn, K.C., Gee, N.A., Ahmed, M.I., Duleba, A.J., Zhao, L., Gee, S.J., Hammock, B.D., and Lasley, B.L., 2008, Triclocarban enhances testosterone action: a new type of endocrine disruptor?: Endocrinology, v.149, p. 1173-1179. 
Coogan, M.A., Edziyie, R.E., La Point, T.W., and Venables, B.J., 2007, Algal bioaccumulation of triclocarban, triclosan, and methyl-triclosan in a North Texas wastewater treatment plant receiving stream: Chemosphere, v. 67, p. 1911-1918.

Coogan, M.A., and La Point, T.W., 2008, Snail bioaccumulation of triclocarban, triclosan, and methyltriclosan in a North Texas, USA, stream affected by wastewater treatment plant runoff: Environmental Toxicology and Chemistry, v. 27, p. 1788-1793.

Cook, S.G., and Jackson, R.S., 1978, The Bailly area of Porter County, Indiana: the final report of a geohistorical study undertaken on behalf of the Indiana Dunes National Lakeshore: Evanston, Illinois, Robert Jackson and Associates, $110 \mathrm{p}$.

Costanzo, S.D., Watkinson, A.J., Murby, E.J., Kolpin, D.W., and Sandstrom, M.W., 2007, Is there a risk associated with the insect repellent DEET (N,N,-diethyl-m-toluamide) commonly found in aquatic environments?: Science of the Total Environment, v. 384, p. 214-220.

Corti, A., Frassinetti, S., Vallini, G., D’Antone, S., Fichi, C., and Solaro, R., 1995, Biotransformation of nonionic surfactants. I. Biotransformation of 4-(1-nonyl)phenol by Candida maltosa isolate: Environmental Pollution, v. 90, no. 1, p. 83-87.

Corvini P.F.X., Meesters, R.J.W., Schaffer, A., Schroder, H.F., Vinken, R., and Hollender, J., 2004, Degradation of a nonylphenol single isomer by Sphingomonas $s p$. Strain TTNP3 leads to a hydroxylation-induced migration product: Applied and Environmental Microbiology, v. 70, p. 6897-6900.

Cousins, I.T., Staples, C.A., Kečka, G.M., and Mackay, D., 2002, A multimedia assessment of the environmental fate of bisphenol A: Human and ecological risk assessment, v. 8, p. 1107-1135.

Cowardin, L.M., V. Carter, F.C. Golet, and LaRoe, E.T., 1979, Classification of wetlands and deepwater habitats of the United States (Reprinted 1992), U.S. Fish and Wildlife Service report FWS/OBS-79/31, 131 p., accessed April 2, 2013 at $h t t p: / / w w w . f w s . g o v / w e t l a n d s / D o c u m e n t s / C l a s s i f i c a t i o n-$ of-Wetlands-and-Deepwater-Habitats-of-the-United-States. $p d f$.

Crane, J.L., Grosenheider, K., and Wilson, C.B., 2010, Contamination of stormwater pond sediments by polycyclic aromatic hydrocarbons (PAHs) in Minnesota: The role of coal tar-based sealcoat products as a source of PAHs: Minnesota Pollution Control Agency, accessed November 20, 2012, at http://www.leg.state.mn.us/docs/2010/other/100587.pdf.
Crane, J.L. and Hennes, S., 2007, Guidance for the use and application of sediment quality targets for the protection of sediment-dwelling organisms in Minnesota: Minnesota Pollution Control Agency, accessed November 20, 2012, at http://www.pca.state.mn.us/index.php/view-document. html? gid $=9163$.

Ferguson P.L. and Brownawell B.J., 2003, Degradation of nonylphenol ethoxylates in estuarine sediment under aerobic and anaerobic conditions: Environmental Toxicology and Chemistry, v. 22, no. 6, p. 1189-1199.

Fishman, M.J., and Friedman, L.C., eds., 1989, Methods for determination of inorganic substances in water and fluvial sediments: U.S. Geological Survey Techniques of Water Resources Investigations, book 5, chap. A1, 545 p.

Fishman, M.J., ed., 1993, Methods of analysis by the U.S. Geological Survey National Water Quality Laboratory; determination of inorganic and organic constituents in water and fluvial sediments: U.S. Geological Survey Open-File Report 93-125, $217 \mathrm{p}$.

Ford, J.C., 2009, Elution chromatography, chap. 145 in Cazes, Jack, ed., Encyclopedia of chromatography (3d ed., print


crcnetbase.com/doi/abs/10.1201/NOE1420084597.ch145.

Griffin, J.J., and Goldberg, E.D., 1983, Impact of fossil fuel combustion on sediments of Lake Michigan: A reprise: Environmental Science and Technology, v.17, p. 244-245.

Halden, R.U., and Paull, D.H., 2004, Analysis of triclocarban in aquatic samples by liquid chromatography electrospray ionization mass spectrometry: Environmental Science and Technology, v. 38, p. 4849-4855.

Halden, R.U., and Paull, D.H., 2005, Co-occurrence of triclocarban and triclosan in U.S. water resources: Environmental Science and Technology, v. 39, p. 1420-1426.

Hardy, M.A., 1984, Chemical and biological quality of streams at the Indiana Dunes National Lakeshore, Indiana, 1978-80: U.S. Geological Survey Water-Resources Investigations Report 83-4208, 95 p.

Hartke, E. J., Hill, J. R. and Reshin, M., 1975, Environmental Geology of Lake and Porter Counties, Indiana-An Aid to Planning. Indiana Geological Survey Special Report no. 11, $57 \mathrm{p}$.

Heidler, J., Sapkota, A., and Halden, R.U., 2006, Partitioning, persistence, and accumulation in diested sludge of the topical antiseptic triclocarban during wastewater treatment: Environmental Science and Technology, v. 40, p. 3634-3639. 
Henrichs, K.D., 1952, Burning peat continues to menace Beverly Shores area: Valparaiso Vidette-Messenger [Indiana], November 14, 1952, accessed September 19, 2012, at http://newspaperarchive.com/valparaiso-vidette-messenger/1952-11-14/.

Hinkle S.R., Weick, R.J., Johnson J.M., Cahill, J.D., Smith, S.G., and Rich, B.J., 2005, Organic wastewater compounds, pharmaceuticals, and coliphage in ground water receiving discharge from onsite wastewater treatment systems near La Pine, Oregon-Occurrence and implications for transport: U.S. Geological Survey Scientific Investigations Report 2005-5055, $98 \mathrm{p}$.

Indiana Administrative Code, 2012, Title 327, Article 2, Rule 1 , Water quality standards applicable to all state waters within the Great Lakes system, Section 6, Minimum surface water quality standards, Table $6-1$, Surface water quality criteria for specific substances: accessed August 21, 2012, at http://www.in.gov/legislative/iac/T03270/A00020.PDF.

Jürgens, M.D., Holthaus, K.I.E., Johnson, A.C., Smith, J.J.L., Hetheridge, M., and Williams, R.J., 2002, The potential for estradiol and ethinylestradiol degradation in English rivers: Environmental Toxicology and Chemistry, v.21, no. 3, p. 480-488.

Kim, Y-S., Katase, T., Sekine, S., Inoue, T., Makino, M., Uchiyama, T., .Fujimoto, Y., and Yamashita, N., 2004, Variation in estrogenic activity among fractions of a commercial nonylphenol by high-performance liquid chromatography: Chemosphere, v. 54, p. 1127-1134.

Kimbrough, K.L., and Dickhut, R.M., 2006, Assessment of polycyclic aromatic hydrocarbon input to urban wetlands in relation to adjacent land use: Marine Pollution Bulletin, v. 52, p. 1355-1363.

Kolpin, D.W., Furlong, E.T., Meyer, M.T., Thurman, E.M., Zaugg, S.D., Barber, L.B., and Buxton, H.T., 2002, Pharmaceuticals, hormones, and other organic wastewater contaminants in U.S. streams, 1999-2000: A national reconnaissance: Environmental Science and Technology, v. 36, p. 1202-1211.

Lawrence, S.J., 2006, Description, properties, and degradation of selected volatile organic compounds detected in ground water - A review of selected literature: U. S. Geological Survey, Open-File Report 2006-1338, 62 p., at http://pubs. usgs.gov/ofr/2006/1338/.

Layton, A.C., Gregory, B.W., Seward, J.R., Schultz, T.W., and Sayler, G.S., 2000, Mineralization of steroidal hormones by biosolids in wastewater treatment systems in Tennessee U.S.A.: Environmental Science and Technology, v. 34, p. 3925-3931.
Lee, K.E., Blazer, V.S., Denslow, N.D., Goldstein, R.M., and Talmage, P.J., 2000, Use of biological characteristics of common carp (Cyprinus carpio) to indicate exposure to hormonally active agents in selected Minnesota streams: U.S. Geological Survey Water-Resources Investigations Report 00-4202, $47 \mathrm{p}$.

Leeming, R., Bate, N., Hewlet, R., and Nichols, P.D., 1998, Discriminating faecal pollution: A case study of stormwater entering Port Phillip Bay, Australia: Water Science and Technology, v. 38, p. 15-22.

Lewis, M.E., 2006, Dissolved oxygen (ver. 2.1): U.S. Geological Survey Techniques of Water-Resources Investigations, book 9, chap. A6., sec. 6.2, June 2006, accessed August 21, 2012, at http://pubs.water.usgs.gov/twri9A6/.

Li, A., Jang, J.K., and Scheff, P.A., 2003, Application of EPA CMB8.2 model for source apportionment of sediment PAHs in Lake Calumet, Chicago: Environmental Science and Technology, v.37, p. 2958-2965.

Lintelmann, J., Katyama, A., Kurihara, N., Shore, L., and Wenzel, A, 2003, Endocrine disrupters in the environment: Pure and Applied Chemistry, v. 75, no. 5, p. 631-681.

Lopes, T.J. and Dionne, S.G., 1998, A review of semivolatile and volatile organic compounds in highway runoff and urban stormwater: U.S. Geological Survey Open-File Report 98-409, 67 p., accessed May 3, 2013 at http://pubs. er.usgs.gov/publication/ofr98409.

MacCoy, D.E., 2006, Fish communities and related environmental conditions of the lower Boise River, southwestern Idaho, 1974-2004: U.S. Geological Survey Scientific Investigations Report 2006-5111, 36 p.

MacDonald, D.D., Ingersoll, C.G., and Berger, T.A., 2000, Development and evaluation of consensus-based sediment quality guidelines for freshwater ecosystems: Archives of Environmental Contamination and Toxicology, v. 39, p. 20-31.

Maloney, T.J., ed., 2005, Quality management system, U.S. Geological Survey National Water Quality Laboratory: U.S. Geological Survey Open-File Report 2005-1263, version 1.3, 9 November 2005, chapters and appendixes variously paged.

Mastalerz, M., Souch, G., Filippelli, G.M., Dollar, N.A.L.L. and Perkins, S.M., 2001, Anthropogenic organic matter in Great Marsh of the Indiana Dunes National Lakeshore and its implications: International Journal of Coal Geology, v. 46, p. 157-177. 
McGraw-Hill Companies, 2003, Biotransformation, in AccessScience: McGraw-Hill Educational Holdings: The McGrawHill Companies, access date July 18, 2007, definition accessed May 3, 2013 at http://toxics.usgs.gov/definitions/ biotransformation.html.

McGraw-Hill Education, 2013, Biodegradation, in AccessScience: McGraw-Hill Educational Holdings accessed May 3, 2013, at $h t t p: / / w w w . a c c e s s s c i e n c e$. com/abstract.aspx?id $=422025 \&$ referURL $=/$ content/ Biodegradation/42202.

Merriam-Webster, 2013, Merriam-Webster Online Dictionary: Merriam-Webster, Incorporated, accessed September 4, 2013, at http://www.merriam-webster.com.

National Park Service, 2012, Cowles Bog Restoration Project: accessed November 15, 2012, at http://www.nps.gov/indu/ naturescience/great-marsh-restoration.htm.

National Park Service, [2006], Great Marsh restoration at Indiana Dunes National Lakeshore: accessed November 15, 2012, at http://www.nps.gov/indu/naturescience/wetlands. htm.

National Research Council, 1997, Innovations in ground water and soil cleanup-From concept to commercialization: Washington, D.C., National Academies Press, 310 p. definition accessed May 3, 2013 at http://toxics.usgs.gov/ definitions/pah.html.

Neff, J.M., Stout, S.A. and Gunster, D.G., 2005, Ecological risk assessment of polycyclic aromatic hydrocarbons in sediments: Identifying sources and ecological hazard: Integrated Environmental Assessment and Management, v. 1, p. 22-33.

O'Dell, J.W., 1993, Method 365.1: Determination of phosphorus by semi-automated colorimetery, revision 2.0, August 1993: U.S. Environmental Protection Agency, Environmental Monitoring Systems Laboratory, Office of Research and Development: Cincinnati, Ohio,accessed August 26, 2012, at http://water.epa.gov/scitech/methods/cwa/bioindicators/ upload/2007_07_10_methods_method_365_1.pdf.

Patton, C.J., and Kryskalla, J.R., 2011, Colorimetric determination of nitrate plus nitrite in water by enzymatic reduction, automated discrete analyzer methods: U.S. Geological Survey Techniques and Methods, book 5, chap. B8, 34 p. accessed August 26, 2012, at http://pubs.usgs.gov/ tm/05b08/.
Patton, C.J., Kryskalla. J.R., 2003, Methods of analysis by the U.S. Geological Survey National Water Quality Laboratory: Evaluation of alkaline persulfate digestion as an alternative to Kjeldahl digestion for determination of total and dissolved nitrogen and phosphorus in water: U.S. Geological Survey Water-Resources Investigations Report 03-4174, 33 p., accessed August 26, 2012, at http://nwql.usgs.gov/Public/pubs/WRIR03-4174/WRIR03-4174.html.

Radtke, D.B., Davis, J.V., and Wilde, F.D., 2005, Specific electrical conductance (ver. 1.2): U.S. Geological Survey Techniques of Water-Resources Investigations, book 9 , chap. A6., sec. 6.3, August 2005, accessed August 21, 2012, http://pubs.water.usgs.gov/twri9A6/.

Rastall, A.C., Neziri, A., Vukonvic, Z., Jung, C., Mijovic, S., Hollert, H., Nikcevic, S., and Erdinger, L., 2004, The identification of readily bioavailable pollutants in Lake Shkodra/ Skadar using semipermeable membrane devices (SPMDs), bioassays and chemical analysis: Environmental Science and Pollution Research, v. 11, p. 240-253.

Ritz, G.F., and Collins, J.A., 2008, pH (ver. 2.0): U.S. Geological Survey Techniques of Water-Resources Investigations, book 9, chap. A6., sec. 6.4, October 2008, accessed August 21, 2012, from http://pubs.water.usgs.gov/twri9A6/.

Routledge, E.J., and Sumpter, J. P., 1996, Estrogenic activity of surfactants and some of their degradation products assessed using a recombinant yeast screen: Environmental Toxicology and Chemistry, v. 15, p. 241-248.

Saim, N., Osman, R., Spian, D.R.S.A., Jaafar, M.Z., Juahir, H., Abdullah, M.P., and Ghani, F.A., 2009, Chemometric approach to validating faecal sterols as source tracer for faecal contamination in water: Water Research, v. 43, p. 5023-5030.

Sapkota, A., Heidler, J., and Halden, R.U., 2007, Detection of triclocarban and two co-contaminating chlorocarbanilides in US aquatic environments using isotope dilution liquid chromatography tandem mass spectrometry: Environmental Research, v. 103, p. 21-29.

Scheeringa, K., 2002, Climate of Indiana: Indiana State Climate Office, accessed April 28, 2011, at http://iclimate.org/ narrative.asp.

Shang, D.Y., MacDonald, R.W., and Ionomou, M.G., 1999, Persistence of nonylphenol ethoxylate surfactants and their primary degradation products in sediments from near a municipal outfall in the Strait of Georgia, British Columbia, Canada; Environmental Science and Technology, v. 33, p. 1366-1372. 
Shedlock, R.J., Cohen, D.A., Imbrigiotta, T.E., and Thompson, T.A., 1994, Hydrogeology and hydrochemistry of dunes and wetlands along the southern shore of Lake Michigan, Indiana: U.S. Geological Survey Open-File Report 92-139, $85 \mathrm{p}$.

Simcik, M.F., Eisenreich, S.J., and Lioy, P.J., 1999, Source apportionment and source/sink relationshipos of PAHs in the coastal atmosphere of Chicago and Lake Michigan: Atmospheric Environment, v. 33, p. 5071-5079.

Sole, M., Lopez De Alda, M., Castillo, M., Porte, C., Ladegaard-Pedersen, K. and Barcelo, D., 2000, Estrogenicity determination in sewage treatment plants and surface waters from the Catalonian area (NE Spain): Environmental Science and Technology, v. 34, p. 5076-5083.

Sposito, G., 2008, The chemistry of soils (2d ed.): New York, Oxford University Press, 344 p.

Staples, C.A., Dorn, P.B., Klečka, G.M., and O’Block, S.T., 1998, A review of the environmental fate, effects and exposures of bisphenol A: Chemosphere, v. 36, no. 10, p. 2149-2173.

Souch, C., Filippelli, G.M., Perkins, S., Dollar, N.L., and Mastalerz, M., 1999, Accumulation rates of heavy metals in wetlands: Indiana Dunes National Lakeshore: Geological Society of America [conference], Denver, Colorado.

Struzeski, T.M., DeGiacomo, W.J., and Zayhowski, E.J., 1996, Methods of analysis by the U.S. Geological Survey National Water Quality Laboratory - Determination of dissolved aluminum and boron in water by inductively coupled plasma-atomic emission spectrometry: U.S. Geological Survey Open-File Report 96-149, 17 p.

Thompson, A. and Goyne, K.W., 2012, Introduction to the sorption of chemical constituents in soils: Nature Education Knowledge, v. 4, no. 4, p. 7, accessed May 3, 2013, at http://www.nature.com/scitable/knowledge/ library/introduction-to-the-sorption-of-chemicalconstituents-94841002.

Thompson, T.A., 1987, Sedimentology, internal architecture and depositional history of the Indiana Dunes National Lakeshore and State Park: Bloomington, Ind., Indiana University, unpublished Ph.D. thesis, 129 p.

Thorpe, K.L., Hutchinson, T.H., Hetheridge, M.J., Scholze, M., Sumpter, J.P., and Tyler, C.R., 2001, Assessing the biological potency of binary mixtures of environmental estrogens using vitellogenin induction in juvenile rainbow trout (Oncorhynchus mykiss): Environmental Science and Technology, v. 35, p. 2476-2481.
U.S. Army Corps of Engineers, 2012, Indiana Harbor and Canal ambient air monitoring program: Construction phase annual report 2011: U.S. Army Corps of Engineers, Chicago District, September 2012, 29 p., accessed September 18, 2012, at http://www.lrc.usace.army.mil/Portals/36/docs/ projects/indianaharbor/reports/2011_ambient_air_rept.pdf.

U.S. Army Corps of Engineers, 2011, Indiana Harbor and Canal ambient air monitoring program: Construction phase annual report 2010: U.S. Army Corps of Engineers, Chicago District, July 2011, 29 p., accessed September 18, 2012, at http://www.lrc.usace.army.mil/Portals/36/docs/projects/ indianaharbor/reports/2010_ambient_air_rept.pdf.

U.S. Army Corps of Engineers, 2005, Guidance for evaluating performance-based chemical data, Engineer manual 200-1-10: U.S. Army Corps of Engineers, June 2005, 129 p., accessed September 4, 2013, at http://publications.usace. army.mil/publications/eng-manuals/EM_200-1-10/EM_2001-10.pdf.

U.S. Census Bureau, 2010, Profile of general population and housing characteristics: 2010 Census summary file: Beverly Shores, IN: accessed August 17, 2012, at http://2010.census. gov/2010census/popmap/ipmtext.php?fl=18:1805158.

U.S. Environmental Protection Agency, 2013, National recommended water quality criteria: United States Environmental Protection Agency, accessed September 4, 2013, at http:// water.epa.gov/scitech/swguidance/standards/criteria/ current/index.cfm.

U.S. Environmental Protection Agency, 2012, Exposure assessment tools and models: Estimation programs interface suite $^{\mathrm{TM}}$ for Microsoft ${ }^{\circledR}$ Windows, v 4.11: United States Environmental Protection Agency, accessed April 7, 2013, at http://www.epa.gov/opptintr/exposure/pubs/episuite.htm.

U.S. Environmental Protection Agency, 2004, Glossary of technical terms: U.S. Environmental Protection Agency, accessed August 31, 2012, at http://www.epa.gov/oust/cat/ TUMGLOSS.HTM.

U.S. Geological Survey, 2013, Emerging contaminants in the environment: U.S. Geological Survey, accessed September 4, 2013, at http://toxics.usgs.gov/regional/emc/.

U.S. Geological Survey, 2006, Collection of water samples (ver. 2.0): U.S. Geological Survey Techniques of WaterResources Investigations, book 9, chap. A4, September 2006, accessed May 3, 2013 at http://water.usgs.gov/owq/ FieldManual/chapter4/pdf/Chap4_v2.pdf.

Van Ginkel, C.G., 1996, Complete degradation of xenobiotic surfactants by consortia of aerobic microorganisms: Biodegradation, v. 7, no. 2, p. 151-164. 
VanMetre, P.C., and Mahler, B.J., 2010, Contribution of PAHs from coal-tar pavement sealcoat and other sources to 40 U.S. lakes: Science of the Total Environment, v. 409, p. 334-344.

Vazquez-Duhalt, R., Marquez-Rocha, F., Ponce, E., Licea, A., and Viana, M., 2005, Nonylphenol, an integrated vision of a pollutant, scientific review: Applied Ecology and Environmental Research, v. 4, p. 1-25.

Watson, L.R., Bayless, E.R., Buszka, P.M., and Wilson, J.T., 2002, Effects of highway-deicer application on groundwater quality in a part of the Calumet aquifer, northwestern Indiana: U.S. Geological Survey Water-Resources Investigations Report 01-4260, 148 p.

Wilde, F.D., ed., 2006, Temperature (ver. 2.0): U.S. Geological Survey Techniques of Water-Resources Investigations, book 9, chap. A6, sec. 6.1: accessed August 21, 2012, from http:// pubs.water.usgs.gov/twri9A6/.

Wilde, F.D., ed., 2004, Cleaning of equipment for water sampling (ver. 2.0): U.S. Geological Survey Techniques of Water-Resources Investigations, book 9, chap. A3, April 2004, accessed August 21, 2012, at http://pubs.water.usgs. gov/twri9A3/.

Wilde, F.D., Radtke, D.B., Gibs, Jacob, and Iwatsubo, R.T., eds., 2004 with updates through 2009, Processing of water samples (ver. 2.2): U.S. Geological Survey Techniques of Water-Resources Investigations, book 9, chap. A5, April 2004, accessed August 21, 2012 at http://pubs.water.usgs. gov/twri9A5/.

Winchester, J.W., and Nifong, G.D., 1971, Water pollution in Lake Michigan by trace elements from pollution aerosol fallout: Water, Air, Soil Pollution, v. 1, p. 50-64.

Writer, J.H., Barber, L.B., Ryan, J., and Bradley, P.M., 2011, Biodegradation and attenuation of steroidal hormones and alkylphenols by stream biofilms and sediments: Environmental Science and Technology, v. 45, p. 4370-4376.
Xie, S., Deng, H., Xiang, B., and Xiang, S., 2008, Detection of trace triclocarban in water sample using solid-phase extraction-liquid chromatography with stochastic resonance algorithm: Environmental Science and Technology, v. 42, p. 2988-2991.

Ying, G., Williams, B., and Kookana, R., 2002, Environmental fate of alkylphenols and alkylphenol ethoxylates - A review: Environment International, v. 28, p. 215-226.

Ying, G.G., Yu, X.Y., and Kookana, R.S., 2007, Biological degradation of triclocarban and triclosan in soil under aerobic and anaerobic conditions and comparison with environmental fate modeling: Environmental Pollution, v. 150, p. 300-305.

Yunker, M.B., Macdonald, R.W., Vingarzan, R., Mitchell, R.H., Goyette, D., and Sylvestre, S., 2002, PAHs in the Fraser River basin: A critical appraisal of PAH ratios as indicators of PAH source and composition: Organic Geochemistry, v. 33, p. 489-515.

Zaugg, S.D., Burkhardt, M.R., Burbank, T.L., Olson, M.C., Iverson, J.L. and Schroeder, M.P., 2006, Determination of semivolatile organic compounds and polycyclic aromatic hydrocarbons in solids by gas chromatography/mass spectrometry: U.S. Geological Survey Techniques and Methods, book 5, chap B3, 44 p.

Zaugg, S.D., Smith, S.G., and Schroeder, M.P., 2006, Determination of wastewater compounds in whole water by continuous liquid-liquid extraction and capillary-column gas chromatography/mass spectrometry: U.S. Geological Survey Techniques and Methods, book 5, chap B4, 30 p.

Zaugg, S.D., Smith, S.G., Schroeder, M.P., Barber, L.B., and Burkhardt, M.R., 2002, Methods of analysis by the U.S. Geological Survey National Water Quality LaboratoryDetermination of wastewater compounds by polystyrenedivinylbenzene solid-phase extraction and capillary-column gas chromatography/mass spectrometry: U.S. Geological Survey Water-Resources Investigations Report 01-4186, $37 \mathrm{p}$. 


\section{Glossary of Selected Terms}

Sources: Alvarez, 2010; Alvarez, Cranor, Perkins, Schroeder, and others, 2008; Bhattacharyya and Johnson, 1977; Chapelle, 2001; Ford, 2009; Indiana Administrative Code, 2012; Lawrence, 2006; MacDonald and others, 2000; McGraw-Hill Companies, 2003; McGraw-Hill Education, 2013, MerriamWebster, 2013; National Research Council, 1997; Routledge and Sumpter, 1996; Sposito, 2008; Thompson and Goyne, 2012; U.S. Army Corps of Engineers, 2005, U.S. Environmental Protection Agency, 2013; VanMetre and Mahler, 2010; U.S. Geological Survey, 2013, and 2006.

Biotransformation - "The series of chemical reactions that occur in a compound, especially a drug, as a result of enzymatic or metabolic activities by a living organism." (McGrawHill Companies, 2013)

Biorecalcitrance - The state of an organic substance or compound as resisting transformation into other chemical compounds or products by biological processes. The root of this term, recalcitrant, is defined as not responsive to treatment (Merriam-Webster, 2013). A biorecalcitrant compound is not readily transformed by biological processes.

Chi-square value - The Chi-square statistic is used in statistical testing to describe "goodness of fit" among different types of normally distributed data (Bhattacharyya and Johnson, 1977). Chi-square values were calculated as the square of the difference in proportional concentrations of a set of compounds (in this report, polycyclic aromatic hydrocarbon compounds or PAHs) divided by the mean of the two values, summed for the 12 PAH compounds, as described by VanMetre and Mahler (2010).

Consensus-based probable effect concentration (PEC) - A type of sediment quality guideline that is intended to identify contaminant concentrations above which harmful effects on sediment-dwelling organisms were expected to occur frequently (MacDonald and others, 2000). The consensus among several types of PEC guidelines were developed for different compounds or groups of compounds by determining the geometric mean of several similar types of sediment quality guidelines, including probable effect levels, effect range median values, severe effect levels, and toxic effect thresholds. Types and sources of the PEC-type guidelines used to define the PEC are in MacDonald and others (2000).

Criterion continuous concentration (CCC) - An estimate of the highest concentration of a material in surface water to which an aquatic community can be exposed indefinitely without resulting in an unacceptable effect (U.S. Environmental Protection Agency, 2013). In Indiana water quality regulations, this term is referred to as the continuous criterion concentration (Indiana Administrative Code, 2012).

Estradiol equivalent factor (EEQ) - This is an estimate of the amount of $17 \beta$-estradiol, a common natural estrogen hormone, that would be required to give an estrogenic response equivalent to that of a complex mixture of chemicals in a water sample. The EEQ is computed to provide a relative measure of estrogenicity of the water exposed to the sorbent materials in the polar organic chemical integrative sampler during its deployment (Alvarez, Cranor, Perkins, Schroeder, and others, 2008).

Estrogenicity - Estrogen-like quality of compounds in a water sample. Estrogens include "various natural steroids (as estradiol) that are formed from androgen precursors, that are secreted chiefly by the ovaries, placenta, adipose tissue, and testes, and that stimulate the development of female secondary sex characteristics and promote the growth and maintenance of the female reproductive system; [this includes] any of various synthetic or semisynthetic steroids (as ethinylestradiol) that mimic the physiological effect of natural estrogens" (MerriamWebster, 2013).

Endocrine disrupting chemicals - "Endocrine disruptors are chemical compounds that interfere with the proper function of endocrine systems in humans and other organisms" (from definition of "environmental endocrine disruptors" in McGrawHill Education, 2013).

Headspace - The volume above a liquid or solid in a closed container (Merriam-Webster, 2013). Headspace in a water sampling context describes the gas phase above the liquid or solid contents of the partially filled, closed sample container.

Isocratic - A type of chromatographic separation in which the mobile phase composition remains constant through the elution (Ford, 2009). A mobile phase is a liquid solvent in liquid chromatography or a carrier gas in gas chromatography. In this report, the term isocratic refers to how the carrier gas is maintained in a constant composition during the extraction of a compound from a sorbent (stationary) phase by maintaining the carrier gas at a constant temperature and pressure.

Microcosm - “Aquifer materials placed into sealed laboratory vessels such as test tubes or serum vials for measurement of microbial activity are referred to as microcosms. Microcosm is defined in the dictionary as 'a community or other unity that is representative of a larger unity.' The reasoning for microcosms is that by understanding the activity of a small portion of an aquifer, much can be learned about the aquifer as a whole" (Chapelle, 2001).

Mineralization - In this report, the process by which organic compounds are converted to simpler inorganic compounds, namely, carbon dioxide and water (and if the organic substances are halogenated, halogen acids). "Mineralization results in complete conversion of a compound to its inorganic mineral constituents [for example, carbon dioxide $\left(\mathrm{CO}_{2}\right.$; from carbon), sulfate or sulfide (from organic sulfur), nitrate or ammonium (from organic nitrogen), phosphate (from organophosphates), or chloride (from organochlorine)]. Since carbon comprises the greatest mass of organic compounds, 
mineralization can be considered in terms of $\mathrm{CO}_{2}$ evolution. Radioactive carbon-14 $\left({ }^{14} \mathrm{C}\right)$ isotopes enable scientists to distinguish between mineralization arising from contaminants and soil organic matter. However, mineralization of any compound is never 100 percent because some of it (10-40 percent of the total amount degraded) is incorporated into the cell mass or products that become part of the amorphous soil organic matter, commonly referred to as humus. Thus, biodegradation comprises mineralization and conversion to innocuous products, namely biomass and humus" (McGrawHill Education, 2013).

Octanol-water partition coefficient $\left(\mathbf{K}_{\mathrm{OW}}\right)$ - "The equilibrium ratio of a chemical's concentration in octanol (an alcoholic compound) to its concentration in the aqueous phase of a two-phase octanol/water system, typically expressed in log units $\left(\log \mathrm{K}_{\mathrm{OW}}\right)$. $\mathrm{K}_{\mathrm{OW}}$ provides an indication of a chemical's solubility in fats (lipophilicity), its tendency to bioconcentrate in aquatic organisms, or sorb to soil or sediment (Lawrence, 2006).

Organic wastewater compounds-A term used in this report to describe a group of organic compounds disposed in wastewater from a variety of human-affected sources. These compounds include disinfectants, flame retardants, flavorings, fragrances, hormones and sterols, nonionic detergents, polycyclic aromatic hydrocarbons, pesticides, pharmaceuticals, solvents, and volatile and semivolatile organic compounds. Many of these compounds are also referred to in scientific literature as "emerging contaminants" (U.S. Geological Survey, 2013)

Polar organic chemical integrative sampler (POCIS) A type of passive sampler "designed to sample the more water soluble organic chemicals with octanol-water partition coefficients $\left(\mathrm{K}_{\mathrm{ow}}\right.$ values) that are less than about 1,000. This includes most pharmaceuticals, illicit drugs, polar pesticides, phosphate flame retardants, surfactants, metabolites and degradation products. Although $\mathrm{K}_{\mathrm{ow}}$ values for steroidal hormones, fragrances, triclosan, and other chemicals related to wastewater effluents are generally greater than 1,000, these compounds are often preferentially sampled by the POCIS" (Alvarez, 2010). Configurations and applications of the POCIS are described in that reference.

Polycyclic Aromatic Hydrocarbons (PAHs) - Polynuclear aromatic hydrocarbon (PAH) - "PAH compounds are a generally hazardous class of semivolatile organic compounds (SVOCs) found in petroleum and emissions from fossil fuel utilization and conversion processes. PAHs are neutral, nonpolar organic molecules that comprise two or more benzene rings arranged in various configurations. Members of this class of compounds have been identified as exhibiting toxic and hazardous properties, and for this reason the [U.S. Environmental Protection Agency] has included 16 PAHs on its list of priority pollutants to be monitored in water and wastes" (National Research Council, 1997).
Pyrogenic - A substance that is produced by heat or as a byproduct of high temperature melting or combustion (Merriam-Webster, 2013). In the context of this report, a pyrogenic compound includes those produced by burning of coal or other fossil fuels.

Semivolatile organic compound (SVOC) - A group of organic compounds that are operationally defined as solventextractable and that can be determined by gas chromatography/mass spectrometry (GC/MS). SVOCs are present in many products, including plastics, dyes, and disinfectants. PAHs, are a subset of SVOCs, produced by burning gasoline, oil, wood, and other fuels. SVOCs typically are hydrophobic and by definition have a moderate tendency to volatilize. These properties control how SVOCs are distributed among air, water, and soil when released into the environment. Because they are hydrophobic and moderately volatile, SVOCs preferentially distribute into organic phases, such as tissue and sediments containing organic carbon.

Radiolabeled compounds - In this report, the term is used to describe several synthetic organic compounds that were prepared to have a radioactive carbon-14 atom $\left({ }^{14} \mathrm{C}\right)$ as a substitute for one of the carbon atoms in their molecular structure. Detection of carbon dioxide $\left(\mathrm{CO}_{2}\right)$ that contain ${ }^{14} \mathrm{C}\left({ }^{14} \mathrm{CO}_{2}\right)$ as a mineralization byproduct were used in microcosm studies presented in this report to indicate and assess the magnitude of biotransformation of the labeled compound in aerobic and anaerobic microcosms.

Sorption- - Following Sposito (2008), any removal of a compound from solution to a solid phase we define as sorption, whereas the inverse process - the release of ions or molecules from soil solids into solution - we define as desorption. These definitions are universally applicable and useful when one has no knowledge of the actual sorption mechanism. When such knowledge is available, we can refer to the accumulation of chemicals at the solid-liquid interface as adsorption, the accumulation of molecules within existing solids as absorption, and the incorporation of substances within an expanding three-dimensional solid as precipitation" (Thompson and Goyne, 2012).

Yeast estrogen screen (YES) - An estrogen-inducible screen developed in a recombinant strain of yeast (Saccharomyces cerevisiae) that in the presence of estrogens (or similarly functional compounds) synthesizes and secretes a sugar compound ( $\beta$-galactosidase) into a culture medium (Routledge and Sumpter, 1996). This response was used to determine whether organic compounds in extracts from polar organic chemical integrative samplers (POCIS) used in this study possessed estrogenic activity that could affect aquatic organisms. 


\section{Selected Quality-Assurance Terms Used in this Report}

Field-blank sample - A type "of basic quality control sample that represents the entire sampling system. The field blank is collected routinely for basic quality control of the sampling process, rather than identifying the specific source of the contamination. The purpose of the field blank sample is to determine the concentrations of target analyte(s) present in the environmental sample that could be attributed to field procedures for equipment cleaning and sample handling. Results include effects from laboratory handling. The field blank provides a measure of the total contamination (bias) present in the sample. The field blank consists of an aliquot of blank water processed sequentially through each component of the sampling system. Blank water is strictly defined within the USGS as specially prepared distilled/deionized water (DIW) that is laboratory produced, quality-controlled, and that carries a certificate of analyte concentrations for each grade and lot of water produced" (U.S. Geological Survey, 2006).

Replicate sample - A type of quality-assurance sample "that is collected close in time and space and in a manner so that the samples are thought to represent virtually the same physical, chemical, and biological properties." Sequential replicate water samples collected by this study were "used to determine variability in some part of the sample collection, processing, and analysis system" (U.S. Geological Survey, 2006).

Concurrent replicate sample - A type of quality-assurance sample "obtained simultaneously using two or more samplers or by using one sampler and alternating collection of samples into two or more compositing containers (Horowitz and others, 1994)." In this report, a concurrent replicate sample of wetland bed sediment was collected and analyzed to "Identify and quantify the variability at the site being sampled" (U.S. Geological Survey, 2006).
Surrogate compound recovery-A type of quality-assurance process prepared and analyzed at the analytical laboratory by adding a spike solution in known concentrations to the environmental water or sediment samples in a manner that does not substantially change the original matrix. A spike solution is a solution having laboratory certified concentrations of selected analytes and that are added in known quantities to a sample. The relative concentrations of the surrogate (target) analytes recovered from the water or sample is used to assess the performance of the laboratory method in measuring concentrations in the environmental media samples. The results can also indicate possible sample matrix interferences and analyte degradation on recovery of analytes from the sample (U.S. Geological Survey, 2006).

Laboratory blank sample - A sample prepared at the analytical laboratory by adding a spike solution in known concentrations to an aliquot of blank water and that is processed sequentially through each component of the analytical system. Blank water is strictly defined in the Field-blank sample definition of this glossary. The relative concentrations of the surrogate analytes for the target compounds of the analysis that are recovered from the water or sample is used to assess the performance of the laboratory method in measuring concentrations from a known sample matrix. The results are used to indicate possible laboratory process interferences, such as when concentrations of target compounds are detected that should not otherwise be present in the blank water or matrix (modified from U.S. Geological Survey, 2006).

Relative percent difference (RPD) - Relative percent difference is the nonnegative difference of the duplicate and environmental sample concentrations $\left(x_{d}\right.$ and $\left.x_{e s}\right)$ divided by the average of the concentrations, expressed as a percentage:

$$
\left.\mathrm{RPD}=\left(\left|x_{e s}-x_{d}\right|\right) /\left(\left(x_{e s}+x_{d}\right) / 2\right)\right) \times 100
$$

The RPD statistic is used in assurance to assess the relative agreement in concentration (precision) between paired duplicate samples (U.S. Army Corps of Engineers, 2005).

\author{
For additional information regarding this \\ publication, contact: \\ Director \\ USGS Indiana Water Science Center \\ 5957 Lakeside Boulevard \\ Indianapolis, IN 46278-1996 \\ (317) 290-3333 \\ email:dc_in@usgs.gov \\ Or visit the USGS Indiana Water Science \\ Center Web site at: \\ http://in.water.usgs.gov \\ Prepared by: \\ USGS Science Publishing Network
}





\section{$\frac{\mathbb{2}}{3}$}



ISSN 2328-0328 (online) http://dx.doi.org/ 10.3133/sir20135186 